\title{
REPORT ON THE STUDY OF THE \\ TAX AND RATE TREATMENT OF RENEWABLE ENERGY PROJECTS
}

\author{
Stanton W. Hadley \\ Lawrence J. Hill \\ Robert D. Perlack \\ Energy Division
}

Date Published: December 1993

Prepared for

Office of Policy, Planning, and Program Evaluation

U.S. DEPARTMENT OF ENERGY

OAK RIDGE NATIONAL LABORATORY

Oak Ridge, Tennessee 37831

Managed by

MARTIN MARIETTA ENERGY SYSTEMS, INC.

for the

U.S. DEPARTMENT OF ENERGY

under Contract No. DE-AC05-84OR21400 


\section{CONTENTS}

LIST OF FIGURES $\ldots \ldots \ldots \ldots \ldots \ldots \ldots \ldots \ldots \ldots \ldots \ldots \ldots \ldots$

LIST OF TABLES $\ldots \ldots \ldots \ldots \ldots \ldots \ldots \ldots \ldots \ldots \ldots \ldots \ldots \ldots$

PREFACE $\ldots \ldots \ldots \ldots \ldots \ldots \ldots \ldots \ldots \ldots \ldots \ldots \ldots \ldots \ldots \ldots \ldots \ldots$

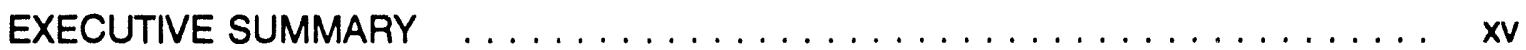

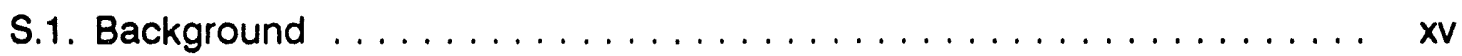

S.2. Conclusions $\ldots \ldots \ldots \ldots \ldots \ldots \ldots \ldots \ldots \ldots \ldots \ldots \ldots$

1. INTRODUCTION AND SUMMARY $\ldots \ldots \ldots \ldots \ldots \ldots \ldots \ldots \ldots \ldots \ldots \ldots$

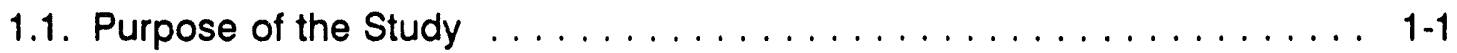

1.2. Scope of the Study $\ldots \ldots \ldots \ldots \ldots \ldots \ldots \ldots \ldots \ldots \ldots$. . . . . . . . . . . .

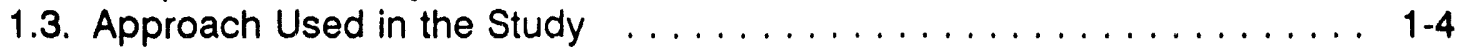

1.4. Overview of Results $\ldots \ldots \ldots \ldots \ldots \ldots \ldots \ldots \ldots \ldots \ldots \ldots \ldots$ 1-7

1.4.1. Effects on Investor-Owned Electric Utilities . . . . . . . . . 1-7

1.4.2. Effects on Nonutility Generators . . . . . . . . . . . . . . . . . . . . 1-10

1.4.3. Barriers To and Incentives For Renewable Technologies . . . . 1-12

1.5. Remainder of the Report .....................1-13

2. DECISIONMAKING CRITERIA AND RESOURCE SELECTION $\ldots \ldots \ldots \ldots \ldots$. . . .

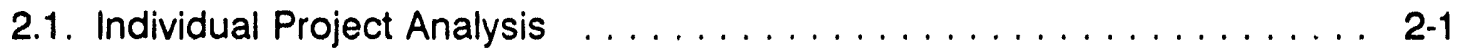

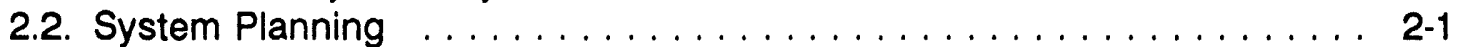

2.3. Effects of Integrated Resource Planning $\ldots \ldots \ldots \ldots \ldots \ldots \ldots$ 2-1

3. GENERATING ALTERNATIVES $\ldots \ldots \ldots \ldots \ldots \ldots \ldots \ldots \ldots \ldots \ldots$

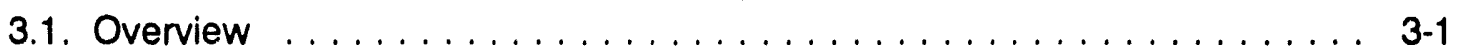

3.2. Renewable Alternatives $\ldots \ldots \ldots \ldots \ldots \ldots \ldots \ldots \ldots \ldots$ 3-6

3.2.1. Biomass . . . . . . . . . . . . . . . . . . . . . .

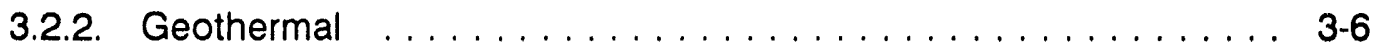

3.2.3. Hydroelectric $\ldots \ldots \ldots \ldots \ldots \ldots \ldots \ldots \ldots \ldots \ldots \ldots . \ldots \ldots$. $\ldots \ldots \ldots$

3.2.4. Solar Thermal $\ldots \ldots \ldots \ldots \ldots \ldots \ldots \ldots \ldots \ldots$. . . . . . . . . . . .

3.2.5. Solar Photovoltaic $\ldots \ldots \ldots \ldots \ldots \ldots \ldots \ldots \ldots$ 3-7

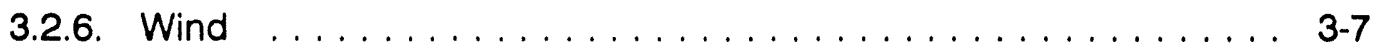

3.3. Conventional Alternatives $\ldots \ldots \ldots \ldots \ldots \ldots \ldots \ldots \ldots \ldots$. $\ldots \ldots \ldots$

3.3.1. Coal . . . . . . . . . . . . . . . . . . . . . . 3-8

3.3.2. Combined Cycle $\ldots \ldots \ldots \ldots \ldots \ldots \ldots \ldots \ldots \ldots$. $3.8 \ldots \ldots \ldots$

3.3.3. Combustion Turbine . . . . . . . . . . . . . . . . . 3-8

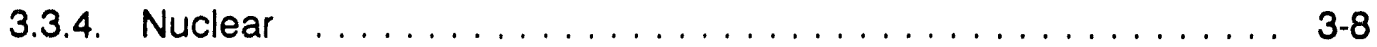

4. TAXATION, RATEMAKING, AND DEFINITION OF SCENARIOS . . . . . . . 4-1

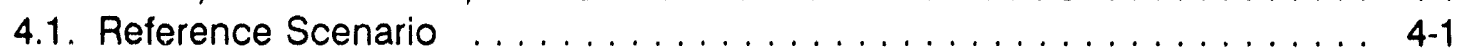

4.2. Alternative Tax Scenarios for IOUs and NUGs . . . . . . . . . . . . 4-3

4.2.1. Effect of All Taxes ... . . . . . . . . . . . . . . . . 4-3

4.2.2. Property Tax Effects . . . . . . . . . . . . . . . . . . . . 4-4

4.2.3. Taxes on Construction and Operating Inputs . . . . . . . . . 4-4 
CONTENTS (CONT.)

4.2.4. State Income Tax Effects . . . . . . . . . . . . . . . . . . . 4-4

4.2.5. Federal Income Tax Effects . . . . . . . . . . . . . . . . 4-5

4.2.6. Effects of Federal Tax Depreciation Lives . . . . . . . . . . . . . 4-5

4.2.7. Effects of Federal Tax Credits . . . . . . . . . . . . . . . 4-7

4.2.8. Effects of the Alternative Minimum $\operatorname{Tax}($ AMT) $\ldots \ldots \ldots \ldots \ldots$ 4-8

4.3. Alternative Ratemaking Scenarios for IOUs . . . . . . . . . . . . . 4-9

4.3.1. Treatment of Construction Work in Progress . . . . . . . . . . . . 4-9

4.3.2. Normalization vs. Flow-Through Tax Accounting . . . . . . . . . 4-9

4.3.3. Fuel Adjustment Clauses . . . . . . . . . . . . . . 4-10

5. SIMULATION RESULTS FOR INVESTOR-OWNED ELECTRIC UTILITIES . . . 5-1

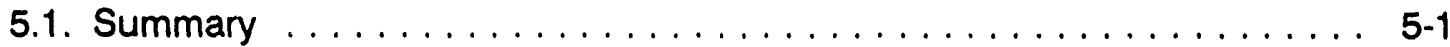

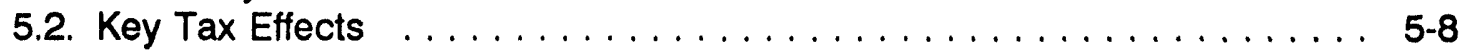

5.2.1. Federal Income Tax Effects . . . . . . . . . . . . . . . 5-8

5.2.2. Property Tax Effects . . . . . . . . . . . . . . . . 5-11

5.2.3. Input Tax Effects . . . . . . . . . . . . . . . . . . . 5-11

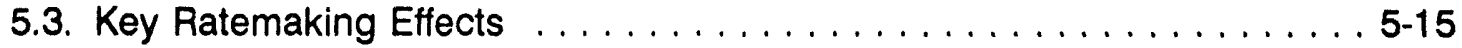

5.3.1. CWIP in Rate Base . . . . . . . . . . . . . . . . . 5-15

5.3.2. Tax Flow-Through tifects . . . . . . . . . . . . . . 5-15

5.4. Sensitivity to Input Assumptions $\ldots \ldots \ldots \ldots \ldots \ldots \ldots \ldots$ 5-17

6. SIMULATION RESULTS FOR NON-UTILITY GENERATORS $\ldots \ldots \ldots \ldots \ldots$. . . . 6-1

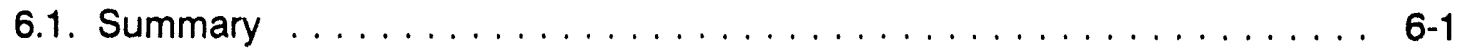

6.2. Key Tax Effects ............................ 6-4

6.2.1. Federal Income Taxes and Credits .............. 6-4

6.2.2. Alternative Minimum Tax Effects . . . . . . . . . . . . . . . 6-9

7. DETERMINING RELATIVE BARRIERS AND INCENTIVES $\ldots \ldots \ldots \ldots \ldots \ldots 7-1$

7.1. Integrated Resource Planning and Resource Selection $\ldots \ldots \ldots \ldots$. $7-1$

7.2. Risk, Public Policy, and Resource Selection . . . . . . . . . . . . . 7-2

7.3. Ratemaking and Taxation Barriers and Incentives $\ldots \ldots \ldots \ldots \ldots$ 7-4

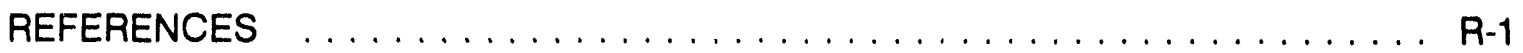

APPENDIX A: DESCRIPTION OF THE MODEL $\ldots \ldots \ldots \ldots \ldots \ldots \ldots \ldots$ A-1

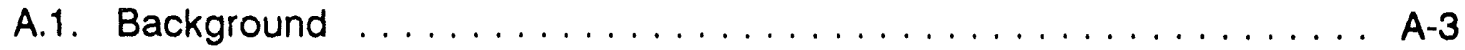

A.2. Investor-Owned Electric Utilities (IOUs) $\ldots \ldots \ldots \ldots \ldots \ldots \ldots \ldots \ldots$ A-3

A.2.1. Overview ......................... A-3

A.2.2. Components of Required Revenues . . . . . . . . . . . A A-5

A.2.2.1. Fuel Costs . . . . . . . . . . . . . . . A-5

A.2.2.2. Other O\&M Expenses . . . . . . . . . . . A-5

A.2.2.3. Depreciation . . . . . . . . . . . . . . . . A-6

A.2.2.4. Taxes . . . . . . . . . . . . . . . . A-8

A.2.2.5. Return on Rate Base ............... A-11 


\section{CONTENTS (CONT.)}

A.2.3. Decisionmaking Criteria $\ldots \ldots \ldots \ldots \ldots \ldots \ldots \ldots \ldots \ldots$ A-12

A.2.3.1. Levelized Cost . . . . . . . . . . . . . . A-12

A.2.3.2. Internal Rate of Return . . . . . . . . . . . . . A A-13

A.2.3.3. Internal Rate of Return-Equity . . . . . . . . . A-13

A.3. Nonutility Generators $\ldots \ldots \ldots \ldots \ldots \ldots \ldots \ldots \ldots \ldots \ldots \ldots$. . . . . . . . . . . .

A.3.1. Overview .......................... A-14

A.3.2. Components of Net Income $\ldots \ldots \ldots \ldots \ldots \ldots \ldots \ldots$. . . . . . . .

A.3.2.1. Revenues . . . . . . . . . . . . . . . . A-14

A.3.2.2. Fuel Costs . . . . . . . . . . . . . . . . A-14

A.3.2.3. Other O\&M Expenses $\ldots \ldots \ldots \ldots \ldots \ldots \ldots \ldots$. . . . . . . .

A.3.2.4. Depreciation $\ldots \ldots \ldots \ldots \ldots \ldots \ldots \ldots \ldots \ldots$.16

A.3.2.5. Taxes $\ldots \ldots \ldots \ldots \ldots \ldots \ldots \ldots \ldots \ldots \ldots \ldots$ A-16

A.3.3. Decisionmaking Criteria $\ldots \ldots \ldots \ldots \ldots \ldots \ldots \ldots \ldots$. . . . . . . .

A.3.3.1. Internal Rate of Return $\ldots \ldots \ldots \ldots \ldots \ldots \ldots$ A-17

A.3.3.2. Internal Rate of Return-Equity $\ldots \ldots \ldots \ldots \ldots$ A-17

APPENDIX B: SIMULATION RESULTS $\ldots \ldots \ldots \ldots \ldots \ldots \ldots \ldots \ldots$ B-1

APPENDIX C: RELATIVE BARRIERS AND INCENTIVES $\ldots \ldots \ldots \ldots \ldots \ldots$ C-1 


\section{LIST OF FIGURES}

Figure

Description

Page

1.1 Schematic Representation of the U.S. Electric Utility Industry . . . . . 1-2

5.1 Levelized Cost Components for Each Technology, IOU

Reference Scenarios $\ldots \ldots \ldots \ldots \ldots \ldots \ldots \ldots$ 5-3

5.2 Effect of All Taxes and Credits on Levelized Cost, Investor-Owned Utilities $\ldots \ldots \ldots \ldots \ldots \ldots \ldots \ldots \ldots$ 5-4

5.3 Effect of Federal Taxes and Credits on Levelized Cost, Investor-Owned Utilities $\ldots \ldots \ldots \ldots \ldots \ldots \ldots \ldots$. $\ldots \ldots \ldots \ldots$

5.4 Effect of Accelerated Depreciation and Tax Credits on Levelized Cost, Investor-Owned Utilities . . . . . . . . . . . . . . 5-10

5.5 Effect of Property Tax Methods on Levelized Cost, Investor-

Owned Utilities $\ldots \ldots \ldots \ldots \ldots \ldots \ldots \ldots \ldots \ldots \ldots \ldots \ldots$ 5-13

5.6 Effect of CWIP Allowance on Cumulative Debt and Equity

Cash Flow, IOU Nuclear Plant . . . . . . . . . . . . . . 5-16

5.7 Effect of Flowing Taxes Through the Rate Base on Annual Ratepayer Payments, IOU Geothermal Plant . . . . . . . . . . . 5-18

6.1 Effect of All Taxes and Credits on IRR, Nonutility Generators . . . . . 6-3

6.2 Effect of Federal Taxes and Credits on IRR, Nonutility Generators .......................... 6-5

6.3 Effect of Alternative Minimum Tax on IRR, Nonutility Generators . . . 6-6

6.4 Effect of Federal Tax Policies on Annual Debt and Equity Cash

Flow, NUG Biomass Plantation .................. 6-7

6.5 Effect of Alternative Minimum Tax on Annual Debt and Equity Cash Flow, NUG Wind Plant . . . . . . . . . . . . . . 6-10

A.1. Ratemaking Formula for Investor-Owned Utilities $\ldots \ldots \ldots \ldots \ldots$ A-4

A.2 Net Income for Non-Utility Generators . . . . . . . . . . . . . A-15 


\section{LIST OF TABLES}

Table

Description

Page

1.1 Summary of Tax Effects on Levelized Cost, Investor-

Owned Utilities . . . . . . . . . . . . . . . . . . . . . . . . . . . . 1-8

1.2 Summary of Ratemaking Effects on Levelized Cost, Investor-

Owned Utilities . . . . . . . . . . . . . . . . . . . . . . . . . . . . 1-10

1.3 Summary of Tax Effects on Internal Rate of Return, Nonutility

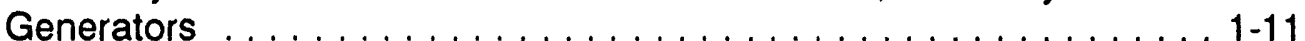

1.4. Summary of Barriers To and Incentives For Renewable

Technologies, Comparison With Conventional Technologies,

Investor-Owned Utilities

1.5 Summary of Barriers To and Incentives For Renewable

Technologies, Comparison With Conventional Technologies,

Nonutility Generators . . . . . . . . . . . . . . . . . . . . . . . . 1-14

3.1 Cost and Engineering Assumptions, Renewable and

Conventional Generating Alternatives ............. 3-2

3.2 Construction Expenditures, Renewable and Conventional

Generating Alternatives $\ldots \ldots \ldots \ldots \ldots \ldots$ 3-4

3.3 Assumed Growth in Fuel Prices, $1993-2022 \ldots \ldots \ldots \ldots$

4.1 Financial Parameters for Investor-Owned Utilities $\ldots \ldots \ldots \ldots \ldots$. . . .

4.2 Financial Parameters for Nonutility Generators . . . . . . . . . . 4-3

4.3 Book and Tax Depreciation Lives, Renewable and Conventional

Generating Alternatives $\ldots \ldots \ldots \ldots \ldots \ldots$ 4-6

5.1 Summary of Tax Effects on Levelized Cost and Internal Rate

of Return, Investor-Owned Utilities . . . . . . . . . . . . . 5-2

5.2 Summary of Ratemaking Effects on Levelized Cost and Internal

Rate of Return, Investor-Owned Utilities . . . . . . . . . . . 5-7 


\section{LIST OF TABLES (Cont.)}

\section{Table}

Description

Page

5.3 Summary of Federal Income Tax Effects on Levelized

Cost and Internal Rate of Return, Investor-Owned Utilities

5.4 Summary of Property Tax Effects on Levelized Cost

and Internal Rate of Return, Investor-Owned Utilities

5.5 Summary of State Input Tax Effects on Levelized Cost and internal Rate of Return, Investor-Owned Utilities

5.6 Summary of Sensitivity Analyses on Input Assumptions, Tax Effects on Levelized Costs, Investor-Owned Utilities

5.7 Summary of Sensitivity Analyses on Input Assumptions, Ratemaking Effects on Levelized Costs, Investor-Owned Utilities

6.1 Summary of Tax Effects on Internal Rate of Return and Internal Rate of Return-Equity, Nonutility Generators

6.2 Summary of Federal Income Tax Effects on Internal Rate of Return and Internal Rate of Return-Equity, Nonutility Generators

6.3 Summary of Alternative Minimum Tax Effects on Internal Rate of Return and Internal Rate of Return-Equity,

Nonutility Generators

7.1 Barriers To and Incentives For Renewable Technologies, Comparison With Conventional Technologies, Investor-Owned Utilities

7.2 Barriers To and Incentives For Renewable Technologies, Comparison With Conventional Technologies, Nonutility Generators

B.1 Tax Simulation Results, Levelized Cost and Internal Rate of Return, Investor-Owned Utilities 
LIST OF TABLES (Cont.)

Table

Description

Page

B.2 Ratemaking Simulation Results, Levelized Cos, and Internal

Rate of Return-Equity, Investor-Owned Utilities . . . . . . . . . B B-4

B.3 Summary of Federal Income Tax Simulation Results, Levelized

Cost and Internal Rate of Return-Equity, Investor-Owned

Utilities

B.4 Summary of Property Tax Simulation Results, Levelized

Cost and Internal Rate of Return, Investor-Owned Utilities

B.5 Summary of State Input Tax Effects, Levelized Cost and

Internal Rate of Return, Investor-Owned Utilities

B.6 Tax Simulation Results, Internal Rate of Return

and Internal Rate of Return-Equity, Nonutility Generators

B.7 Summary of Federal Income Tax Simulation Results, Internal

Rate of Return and Internal Rate of Return-Equity,

Nonutility Generators

B.8 Summary of Alternative Minimum Tax Results, Internal

Rate of Return and Internal Rate of Return-Equity,

Nonutility Generators

B.9 Levelized Cost Components, Biomass/Dedicated Plant

B.10 Levelized Cost Components, Biomass/Waste Plant . . . . . . . . B-12

B.11 Levelized Cost Components, Geothermal .............. B-13

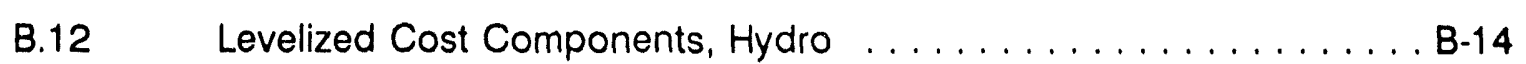

B.13 Levelized Cost Components, Solar/Photovoltaic . . . . . . . . . . B-15

B.14 Levelized Cost Components, Solar/Thermal ............. B-16

B.15 Levelized Cost Components, Wind ............... B-17

B.16 Levelized Cost Components, Coal . . . . . . . . . . . . . B-18 
LIST OF TABLES (Cont.)

\section{Table}

Description

Page

B.17 Levelized Cost Components, Combined Cycle . . . . . . . . . . B-19

B.18 Levelized Cost Components, Combustion Turbine . . . . . . . . . . B-20

B.19 Levelized Cost Components, Nuclear . . . . . . . . . . . . . B-21

C.1 Comparison of Tax Effects on Renewables to Conventionals, Investor-Owned Utilities $\ldots \ldots \ldots \ldots \ldots \ldots \ldots$. . . . . . . . . .

C.2 Comparison of Ratemaking Effects on Renewables to Conventionals, Investor-Owned Utilities ............... C-4

C.3 Comparison of Tax Effects on Renewables to Conventionals, Nonutility Generators . . . . . . . . . . . . . . . . C-5

C.4 Comparison of Tax Effects on Renewables to Conventionals, Nonutility Generators . . . . . . . . . . . . . . . . . C-6 


\section{PREFACE}

Although this study was conducted at Oak Ridge National Laboratory (ORNL), it was a collaborative effort between the authors at ORNL and staff of the Office of Policy, Planning, and Program Evaluation (PPPE) of the U.S. Department of Energy (DOE) and members of the National Association of Regulatory Utility Commissioners (NARUC). Extensive discussions were held on the scope of the study, assumptions used to characterize the generating technologies, modeling scenarios, discussions of results, and the like over a six-month period.

Paul Carrier led the effort at DOE. Six state commissioners were represented: (1) Commissioner Elizabeth Paine (Maine), Commissioner Edward M. Meyers (District of Columbia), Commissioner Ralph Nelson (Idaho), Commissioner J. Terry Deason (Florida), Commissioner James Byrne (Utah), and Chairman Richard Cowart (Vermont). Doug Bauer, the head of the Washington office of ORNL's Energy Division and Russ Profozich of DOE's PPPE Office, actively participated in the discussions over the course of the project.

Many people reviewed early drafts of this study and provided very useful comments as the document evolved over time. However, we would especially like to thank Dan Alpert of Sandia National Laboratories (temporarily assigned to DOE Washington at the time of his reviews) and Eric Hirst of Oak Ridge National Laboratory who provided 'technical reviews' of the document.

Finally, although an attempt was made to include all of the important input assumptions, model documentation, and simulation results in this document, some were excluded to hold it to a manageable length. All of the information, however, is available from the authors upon request. 


\section{EXECUTIVE SUMMARY}

\section{S.1. BACKGROUND}

This study was conducted in response to Section 1205 of the Energy Policy Act of 1992 (EPACT), requiring the U.S. Department of Energy in conjunction with state regulatory commissions to determine if conventional tax measures and ratemaking procedures provide economic barriers to or incentives for the adoption of renewable electric generating plants compared to conventional ones. For this study, we defined barriers and incentives in terms of financial criteria used by investor-owned utilities (IOUs) and nonutility electricity generators (NUGs) when making decisions on technologies for new generating plants. For 1OUs, the major criterion used was the levelized cost of producing power over the useful life of the technology. For NUGs, the major criterion used was the internal rate of return.

Clearly, there are many factors outside the scope of this study that relate to the decisionmaking process of IOUs and NUGs. This study to determine barriers and incentives does not attempt to determine which technologies would most likely be adopted by IOUs and NUGs. Technologies are only cost (in)effective relative to a given power system and its set of internal and external conditions. Other technology-related factors such as availability, dispatchability, diversity, and reliability of generating alternatives are also considered in the decisionmaking process used by IOUs and NUGs. The results of this study show only the relative impact of certain tax measures and ratemaking procedures on financial criteria that IOUs and NUGs use as inputs to make technology-adoption decisions. Where these tax measures and ratemaking procedures provide incentives for an alternative, they increase the likelihood that the alternative will be selected by IOUs or NUGs when making generating-resource decisions.

In quantifying the parameters of the seven renewable and four conventional generating options studied, we used today's 'conventional wisdom' on the values of variables defining the technologies. We did not speculate on the technological evolution of the generating options, consequent changes in their costs, and changes in their attractiveness to IOUs and NUGs in the future.

Consistent with the direction provided by the legislation, this study was limited to the portions of the electric power industry that make decisions on generating technologies. We did not investigate barriers or incentives that may result from tax policies affecting other segments of the fuel cycle, such as incentives for production of fossil fuels. ${ }^{1}$ It was also not possible to quantify the ratemaking treatment of risks. For example, the ratemaking procedure of passing through the costs of fuel to customers removes the risk of unexpected fuel price fluctuations for decisionmakers selecting conventional technologies. The structure of financial, labor, materials, fuel, and

\footnotetext{
${ }^{1}$ An analysis of the total fuel cycle was not included in this study for two reasons. First, Section 1205 clearly states that the study is to evaluate barriers and incentives for renewable power plants. A second reason is that Section 3015 of EPACT requires that the National Academy of Sciences conduct a study on energy subsidies.
} 
purchased power contracts are also beyond the scope of this study. Finally, the transmission and distribution of electric power was not studied.

\section{S.2. CONCLUSIONS}

The study results show that tax measures and ratemaking procedures are both barriers and incentives for renewable energy power plants, depending on the measure or procedure and whether the decisionmaker is an IOU or a NUG. More specifically, for the taxes and ratemaking procedures that were modeled, the study shows:

- Federal income tax laws provide incentives for lOUs to invest in solar, wind, geothermal, and dedicated-plantation biomass technologies. These incentives result from short tax depreciation lives and the recently enacted 1.56/kWh production tax credit for dedicated-plantation biomass and wind technologies.

- In addition to short tax depreciation lives and the production tax credit, the investment tax credit for solar and geothermal technologies also provides incentives for a NUG to adopt renewable technologies if the NUG is not subject to the alternative minimum tax (AMT).

- If a NUG is subject to the AMT, the NUG is not able to take full advantage of the federal tax incentives for renewables and federal tax laws become a barrier to the adoption of renewable technologies.

- Local property taxes are barriers to the adoption of hydro, solar, and wind technologies. This conclusion is robust under different assumptions about the bases used for calculating property taxes.

- For the ratemaking procedures for lOUs that we modeled, tax normalization is an incentive for hydro, solar, and wind technologies because this procedure allows utilities to use short tax depreciation lives.

- Although we were not able to model the procedure of passing through the risk of fuel-price fluctuations to ratepayers, this ratemaking procedure generally is a barrier to the adoption of renewable technologies. 


\section{INTRODUCTION AND SUMMARY}

\subsection{PURPOSE OF THE STUDY}

This study was conducted in response to the requirements of Section 1205 of the Energy Policy Act of 1992 (EPACT), which states:

The Secretary (of Energy), in conjunction with State regulatory commissions, shall undertake a study to determine if conventional taxation and ratemaking procedures result in economic barriers to or incentives for renewable energy power plants compared to conventional power plants.

The purpose of the study, therefore, is not to compare the cost-effectiveness of different types of renewable and conventional electric generating plants. Rather, it is to determine the relative impact of conventional ratemaking and taxation procedures on the selection of renewable power plants compared to conventional ones.

To make this determination, we quantify the technical and financial parameters of renewable and conventional electric generating technoiogies, and hold them fixed throughout the study. Then, we vary taxation and ratemaking procedures to determine their effects on the financial criteria that investor-owned electric utilities (IOUs) and nonutility electricity generators (NUGs) use to make technology-adoption decisions. In the planning process of a typical utility, the opposite is usually the case. That is, utilities typically hold ratemaking and taxation procedures constant and look for the least-cost mix of resources, varying the values of engineering and firancial parameters of generating plants in the process.

\subsection{SCOPE OF THE STUDY}

The enabling legislation for this study also defines its scope. That is, the legislation requires that we address "barriers to or incentives for renewable energy power plants compared to conventional power plants." This suggests, first, that we limit the study to portions of the electric power industry that make decisions on the adoption of generating technologies and, second, that we focus on financial criteria that decisionmakers use to adopt technologies to see if there are tax measures or ratemaking procedures that provide barriers and/or incentives for the selection of generating technologies.

In Figure 1.1, we indicate in shaded areas the position of these decisionmakers in the context of the extended U.S. electric power industry. ${ }^{1}$ The extended industry consists of (1) fuel suppliers for electricity generation; (2) financing, labor, materials, fuel, and purchased power contracted for by IOUs and NUGs to generate power; (3) the electric power industry, including IOUs, state and municipally owned utilities, federal power projects, and rural electric cooperatives; and (4) export, wholesale and end-use

\footnotetext{
${ }^{1}$ For the sake of clarity in Figure 1.1, we include the total set of inputs used to produce electricity for IOUs only. We excluded these inputs for NUGs to simplify the diagram.
} 
Figure 1.1

Schematic Representation of the U.S. Electric Utility Industry

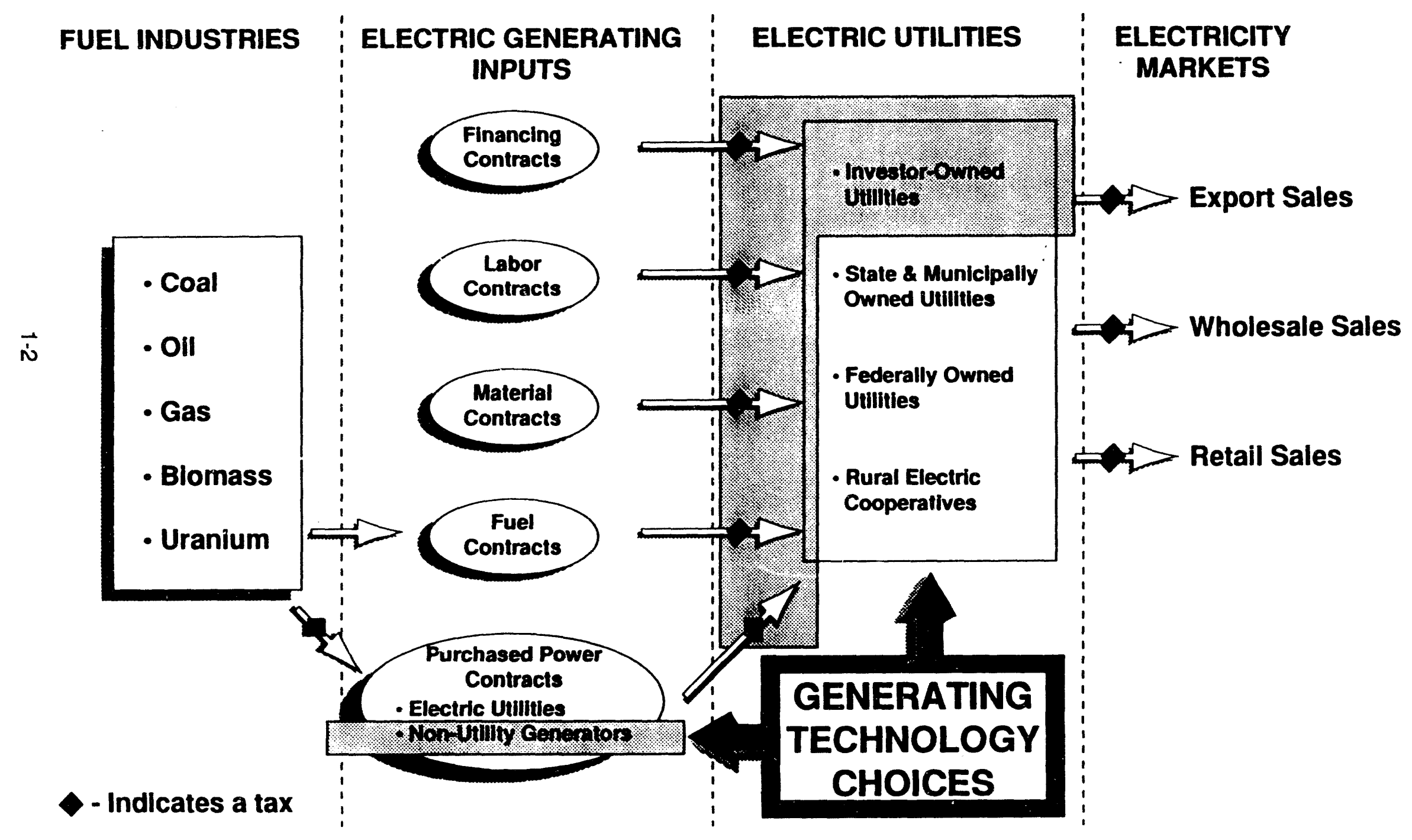


electricity sales. As indicated by the shaded areas of Figure 1.1, the applicable decisionmakers under Section 1205 of EPACT are IOUs and NUGs. The latter consist of qualifying facilities (QFs) and nonqualifying facilities (non-QFs). In 1991, QFs accounted for 75 percent of the electric generating capacity of NUGs (Energy Information Administration, 1993c). ${ }^{2}$

As Figure 1.1 indicates, the scope of the study defined by EPACT's Section 1205 means that we do not consider in depth four other important features of the extended U.S. electric power industry:

- the entire fuel cycles of the energy used to produce electric power;

- the structure of the financial, labor, materials, fuel, and purchased-power contracts entered into by IOUs and NUGs;

- utilities other than those owned by the private sector (i.e., IOUs); and

- the transmission and distribution of electricity beyond the busbar (i.e., export, wholesale, and retail sales).

However, as indicated in Figure 1.1, we do include the sales and labor taxes incurred by IOUs and NUGs in constructing generating facilities and running them. We do not include those same types of taxes incurred by purchasers of electric power beyond the busbar. We discuss these four portions of the extended industry in turn:

Clearly, historical and current policy measures that have shaped the development of electric generating technologies and energy industries upstream from the production of electric power are important factors in explaining the adoption of electric generating technologies by both IOUs and NUGs today and, as such, would be interesting topics of study. For example, development of some energy forms have been subsidized over the years, giving them a competitive advantage in today's marketplace. ${ }^{3}$ Also, an examination of the entire fuel cycles of certain technologies suggest that some have fared better from policy initiatives than others. ${ }^{4}$ However, these issues are beyond the scope of Section 1205 of EPACT.

Second, the management of electric utilities enter into many different types of contracts related to financing, labor matters, material purchases, energy requirements, and purchased power. The structure of some of these contracts may provide

\footnotetext{
IIn 1991, NUGs owned 48,200 MW of capacity. Of this amount, QFs owned 75 percent of it (i.e, cogenerators owned 59 percent and small power producers using renewable energy forms 16 percent); nonQFs owned the remainder (cogenerators 14 percent and independent power producers and other commercial/industrial establishments 11 percent). In 1992, EPACT created the exempt wholesale generator (EWG), another type of non-QF. EWGs differ from QFs in that (1) they are not required to meet PURPA's cogeneration or renewable fuels limitations and (2) utilities are not required to purchase power from EWGs.

${ }^{3}$ For recent studies on energy subsidies, soe The Alliance to Save Energy (1993) and Energy Information Administration (1992). Also, Section 3015 of EPACT requires that the National Academy of Sciences conduct a study on energy subsidies and report to Congress by April 24, 1994.

${ }^{4}$ See, for example, Oak Ridge National Laboratory and Resources for the Future (1992).
} 
(dis)incentives for entering into them. For example, the structure of a long-term fuelsupply contract may not be appealing to an electric utility for any number of reasons, including escalation costs over time, fuel delivery dates, and the like. Or, the structure of a purchased-power contract may provide (dis)incentives for an electric utility to purchase power from a given source. ${ }^{5}$ Again, while contractual issues are important in the electric power industry, the structure of contracts is well beyond the scope of EPACT's Section 1205.

Third, the U.S. electric power industry consists of IOUs and, from Figure 1.1, different types of publicly owned systems, including state and municipal utilities, federal power projects (five power marketing agencies and the Tennessee Valley Authority), and rural electric cooperatives. ${ }^{6}$ Although the investor-owned segment accounts for nearly 80 percent of the industry in terms of sales and investment, publicly owned systems also make technology-adoption decisions. We focus here on IOUs because, for one, publicly owned systems are not subject to federal income taxes and, therefore, federal tax policy-by definition--is neither an incentive nor barrier to the adoption of renewable technologies compared to conventional ones. Also, even in the minority of cases in which publicly owned utilities are regulated by state commissions, they are not generally subject to rateof-return reyulation as are IOUs. Therefore, ratemaking barriers and incentives do not exist for publicly owned electric utilities as they do for IOUs. ${ }^{7}$

Finally, in this study, we consider electric power generation up to the busbar. No attempt is made to look beyond electric power generation at, for example, incentives and barriers to the use of the solar photovoltaic technology on transmission systems to enhance reliability. And, from Figure 1.1, because electric utilities do not incur the taxes that may be applied to export, wholesale, and retail electricity sales, these taxes are also not considered a barrier to or incentive for adoption of renewable and conventional generating technologies.

\subsection{APPROACH USED IN THE STUDY}

To conduct this study, we first quantified the capital and operating parameters of 11 electric generating alternatives, seven renewable and four conventional. The 11 options are:

- biomass with dedicated-plantation feedstock,

- biomass with waste-wood feedstock

- geothermal

\footnotetext{
${ }^{5}$ For a discussion of the types of power contracts negotiated by NUGs, see Edison Electric Institute (1992).

6echnically, rural electric cooperatives are not publicly owned utilities. However, because they are not subject to federal income taxes and their capital costs are subsidized, they are generally treated as publicly owned (Hill, 1988).

${ }^{7}$ For a more lengthy discussion of these tax and ratemaking issues, see Hill (1988).
} 


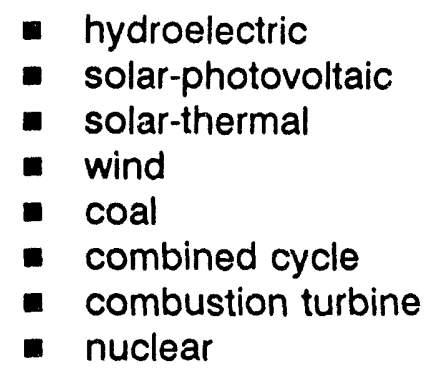

Each of the alternatives was assigned a hypothetical work load in a power system, defined by its capacity factor. For example, the biomass and geothermal renewable options are base-load plants and, therefore, given high capacity factors. On the other hand, a combustion turbine unit is a peaking unit and, therefore, given a low capacity factor. These issues are discussed fully in Section 3. The 11 technologies--and their associated capital and operating costs--are technologically and financially feasible at the present time. That is, we made no attempt to speculate on expected changes in the costs of the technologies in the future. Also, all of the values defining the parameters are in constant 1991 dollars as is the entire analysis. ${ }^{8}$ However, as shown in Section 5.4 in which the results of our sensitivity studies are presented, conducting the analysis in current dollars has no bearing on the conclusions.

Second, we constructed a financial regulatory model of the electric utility industry that can handle ratemaking procedures and tax measures used in the U.S. electric utility industry, including federal, state, and local taxes, the treatment of construction work in progress, normalized vs. flow-through tax accounting, and fuel adjustment clauses. The model is documented in Appendix A.

Third, we defined decisionmaking criteria used to evaluate generating technologies. Because we examine incentives and barriers for both IOUs and NUGs, we use two sets of decisionmaking criteria. For IOUs, we use primarily the levelized cost of producing electricity from each of the 11 alternatives and, secondarily, their internal rate of return. We do not look at interactions among the technologies within a given power delivery system. Rather, we use individual project analysis of the type that would be used to develop screening curves in electric-utility planning. Recognizing that NUGs are not subject to rate-of-return regulation as are lOUs, we use the total internal rate of return (IRR) and IRR-equity as measures of financial attractiveness for NUGs.

Under certain circumstances, it would be more appropriate to use IRR-equity as the primary financial criterion for NUGs. This is especially true in analyzing individual projects in which detailed financing information is known. Because we conducted this study at an aggregated level, financial returns are calculated on the basis of a 'generic project.' In real-world applications in which the relationships among project type, creditworthiness of the investor, leveraging of debt, and repayment schedules are clearly defined, values of IRR-equity more accurately reflect the true return to equity shareholders. In this study, the values of IRR-equity are included for information purposes

\footnotetext{
${ }^{8}$ This is consistent with the approach recommended by the Electric Power Research Institute (1989).
} 
only. $^{9}$

Fourth, we define a reference case for each of the 11 technologies and two ownership types. In the reference case, we attempt to capture as closely as possible the current tax measures and ratemaking procedures for IOUs and taxes for NUGs. In the alternative scenarios, we estimate the effects of these taxes and procedures, include effects of the following:

- all taxes,

- local property taxes,

- taxes on construction and operating inputs,

- state income taxes,

- federal income taxes,

- accelerated federal tax depreciation under the mc dified accelerated cost recovery system provided for by the Tax Reform Act of 1986,

- federal production and investment tax credits for various renewable technologies,

- an alternative minimum tax for NUGs,

- including construction work in progress (CWIP) in the rate base for IOUs,

- flow-through tax accounting for IOUs, and

- a fuel adjustment clause for IOUs.

Fifth, using the financial regulatory model, we simulated the reference and alternative scenarios for both IOUs and NUGs. The results for the alternative scenarios were then indexed to the reference case. Comparing results for the scenarios indicates the direction and extent to which tax measures and ratemaking procedures affect the values of the decisionmaking criteria and, hence, whether or not the measures and procedures are barriers or incenives for individual technologies. For example, comparing values of levelized cost for the case in which all construction work in process is allowed in the rate base and the reference case in which no CWIP is allowed shows whether or not the ratemaking treatment of CWIP is a barrier or incentive for adoption of a technology by an IOU.

Finally, we used the ratios calculated in the fifth step to define barriers and incentives for renewable technologies compared with conventional ones. To accomplish this, we examined the ratios of each renewable technology to see if the ratios are significantly different from the corresponding ones for conventional technologies. Significance was defined in terms of a five-percent threshhold in comparing the ratios for a renewable technology to the average value of the ratios of conventional technologies for each of the tax measures and ratemaking procedures. For lOUs, if the value of the ratio for a renewable technology was more than five percent less than the corresponding average value for conventional technologies, the measure or procedure is an 'incentive'

\footnotetext{
${ }^{9}$ The results using total IRR and IRR-equity are very similar and major conclusions of the report would not change if IRR-equity were used as the sole decisionmaking criterion. The interested reader should review the results in Appendix $B$ for confirmation of this conclusion.
} 
for the adoption of that renewable technology compared to conventional ones. Similarly, if the value of the ratio for a renewable technology is more than five percent greater than the corresponding average value for conventional technologies, the measure or procedure is a 'barrier' to acoption of that renewable technology compared to conventional ones. Because the decisionmaking criterion for NUGs is the internal rate of return rather than levelized cost, the percentage differences from the average value for conventional technologies are reversed in determining barriers and incentives for renewable technologies.

\subsection{OVERVIEW OF RESULTS}

\subsubsection{Effects on Investor-Owned Electric Utilities}

The data in Table 1.1 are a summary of the tax simulation results for IOUs. All of the data are indexed to the reference case which was designed to be 'representative' of the tax and ratemaking situations of a typical IOU. Specifically, (1) federal taxes on income are 35 percent and various federal tax incentives such as accelerated depreciation and investment and production tax credits are included; (2) state taxes on income are six percent; (3) local taxes on property (valued on the basis of net book value) are three percent; (4) no CWIP is allowed in the rate base; and (5) the benefits of accelerated tax depreciation are normalized.

By indexing the results of the alternative scenarios to the reference case, we put the data in Table 1.1 on a ratio basis, with values greater than 1.00 representing increases in costs as a result of the various tax measures and values less than 1.00 representing decreases. Therefore, using our definition of barriers and incentives, the 0.97 'effect of all taxes' for dedicated-plantation biomass systems indicates that the taxes imposed on these systems--i.e., the sum of local, state, and federal taxes--are incentives to adopting that technology because these taxes decrease the levelized cost of producing electricity. On the other hand, the 1.19 result for waste-wood biomass systems indicates that imposing these same taxes on that technology is a barrier to adopting it by IOUs because the taxes increase its levelized cost. Of course, it is these kind of results--and, more important, their causes-- which are the subject of this study.

The results presented in Table 1.1 are disaggregated in Section 5. That is, many more simulations for each category of taxes were run than are presented in the summary data of Table 1.1. In Section 5.2.1, we present and discuss federal taxes in greater detail. In Section 5.2.2, we present and interpret results using different bases for calculating property taxes. Finally, in Section 5.2.3, we discuss input taxes at greater length.

As indicated in Table 1.1, local, state, and federal taxes and credits taken together are a barrier to adopting five of the seven renewable and all conventional technologies. The largest barrier is provided hydro in which taxes increase the levelized cost by 40 percent over the reference case. Taxes are an incentive for dedicated-plantation biomass and wind technologies because of the financial advantages of the $1.5 \mathrm{c} / \mathrm{kWh}$ production tax credit which override all other tax effects. This will be discussed in greater detail in Sections 5.2.1 for IOUs and 6.2.1 for NUGs. 
Table 1.1

Summary of Tax Effects on Levelized Costs, Investor-Owned Utilities

(Cost Ratio of Case with Taxes to Case Without Taxes)

\begin{tabular}{|c|c|c|c|c|c|}
\hline Generating Type & $\begin{array}{l}\text { Effect of } \\
\text { Including } \\
\text { All Taxes } \\
\text { and Credits }\end{array}$ & $\begin{array}{l}\text { Effect of } \\
\text { Including } \\
\text { Property Taxes }\end{array}$ & $\begin{array}{c}\text { Effect of } \\
\text { Including } \\
\text { Input Taxes }\end{array}$ & $\begin{array}{c}\text { Effect of } \\
\text { Including } \\
\text { State } \\
\text { Income Taxes }\end{array}$ & $\begin{array}{l}\text { Effect of } \\
\text { Including } \\
\text { Federal Taxes } \\
\text { and Credits }\end{array}$ \\
\hline Renewable & í & i & & & $\begin{array}{l}1 \\
\text { int }\end{array}$ \\
\hline Biomass-Plantation & 0.97 & 1.09 & 1.07 & 0.99 & 0.85 \\
\hline Biomass-Waste & 1.19 & 1.08 & 1.06 & 1.01 & 1.03 \\
\hline Geothermal & 1.16 & 1.11 & 1.07 & 1.00 & 0.98 \\
\hline Hydro & 1.40 & 1.24 & 1.07 & 1.01 & 1.04 \\
\hline Solar-Photovoltaic & 1.27 & 1.27 & 1.07 & 0.99 & 0.95 \\
\hline Solar-Thermal & 1.24 & 1.23 & 1.07 & 0.99 & 0.95 \\
\hline Wind & 0.91 & 1.31 & 1.10 & 0.97 & 0.71 \\
\hline Conventional & & 1 & & & $i$ \\
\hline Coal & 1.22 & 1.09 & 1.07 & 1.01 & 1.04 \\
\hline Combined Cycle & 1.18 & 1.07 & 1.06 & 1.00 & 1.03 \\
\hline Combustion Turbine & 1.18 & 1.09 & 1.06 & 1.00 & 1.02 \\
\hline Nuclear & 1.20 & 1.09 & 1.07 & 1.00 & 1.03 \\
\hline
\end{tabular}

Source: Section 5 in Text

Ratios greater than 1.0 indicate barriers; ratios less than 1.0 indicate incentives.

a Because of multiple effects, individual tax effects cannot be summed to obtain the total effect. 
Property taxes, based on the net book value of property, plant, and equipment, increase the levelized cost of all technologies. Therefore, property taxes are a barrier for the adoption of both conventional and renewable technologies. Looking at individual technologies, property taxes increase the levelized costs of renewable technologies more than conventional ones, especially for hydro, solar, and wind. The reason is that these technologies are more capital intensive--i.e., higher capital-operating ratios (See Figure 5.1 in Section 5).

Taxes on inputs used to construct generating plants (i.e., sales taxes on energy and materials, and payroll taxes on labor) and run them (i.e., sales taxes on operation and maintenance expenses and payroll taxes on labor) affect renewable and conventional technologies in a similar manner and to generally the same degree. Because they increase their levelized costs, input taxes are barriers to adopting all technologies.

State income taxes have a nominal effect on all technologies. They are incorporated in a manner similar to federal income taxes (i.e., same tax-book depreciation lives, normalized accounting for IOUs), but their effects are less than federal income taxes because a six-percent rate rather than a 35-percent rate is used.

Federal income taxes have very different effects on conventional and renewable technologies. For all conventional technologies, the effect of federal income taxes is to increase their levelized cost and, therefore, pose a barrier for adopting the technologies. With the exception of waste biomass and hydro, this is not the case for renewable technologies. Here, the effect of federal taxes is to reduce the levelized cost of the technologies and, theretore, provide an incentive for their adoption. The reasons are the certain provisions of the federal tax code allowing greater accelerated depreciation rates for most renewable technologies than conventional ones, an investment tax credit for solar and geothermal technologies, and a $1.5 \mathrm{c} / \mathrm{kWh}$ production credit for dedicatedplantation biomass and wind technologies. These effects are discussed in greater detail in the context of federal taxes in Sections 5 and 6.

In Table 1.2, we summarize the simulation results for ratemaking procedures used by IOUs. The reference case for the results in Table 1.2 is the same as that used for Table 1.1. The ratios also have the same interpretation as Table 1.1.

Allowing all CWIP in the rate base has a nominal effect on the levelized costs of all generating technologies, renewable and conventional. The major effect of CWIP is on cash flow, and not the levelized cost of the technologies. This is illustrated in Figure 5.6 in Section 5. Similar to the effects of allowing CWIP in the rate base, lagging the time period over which fuel costs are allowed for ratemaking purposes has a nominal effect on the levelized cost of the technologies.

Flowing the tax benefits of accelerated depreciation directly to ratepayers in the year in which the benefits are received for tax purposes--rather than normalizing them and creating a deferred reserve--increases the levelized costs of all technologies because current tax law also requires that tax depreciation lives increase when flow-through tax accounting is used. Normalized vs. flow-through accounting is discussed in greater detail in Section 4. 
Table 1.2

Summary of Ratemaking Effects on Levelized Cost

Investor-Owned Utilities

(Cost Ratio of Case with Ratemaking Procedure to Caso Without)

\begin{tabular}{|c|c|c|c|}
\hline Generating Type & $\begin{array}{l}\text { Effect of Not } \\
\text { Including CWIP } \\
\text { in Rate Base }\end{array}$ & $\begin{array}{c}\text { Effect of } \\
\text { Normalizing } \\
\text { Taxes in Rate Base }\end{array}$ & $\begin{array}{l}\text { Effect of Automatic } \\
\text { Fuel Adjustments }\end{array}$ \\
\hline
\end{tabular}

Renewable

$\begin{array}{llll}\text { Biomass-Plantation } & 1.00 & 0.98 & 1.00 \\ \text { Biomass-Waste } & 1.00 & 0.98 & 1.00 \\ \text { Geothermal } & 1.00 & 0.94 & 1.00 \\ \text { Hydro } & 1.00 & 0.90 & 1.00 \\ \text { Solar-Photovoltaic } & 1.00 & 0.89 & 1.00 \\ \text { Solar-Thermal } & 1.00 & 0.90 & 1.00 \\ \text { Wind } & 1.00 & 0.89 & 1.00\end{array}$

Conventional

Coal

1.00

$0.98 \quad 1.00$

Combined Cycle

1.00

$0.98 \quad 1.00$

Combustion Turbine

1.00

0.98

1.00

Nuclear

1.00

1.03

1.00

Source: Section 5 in Text

\subsubsection{Effects on Nonutility Generators}

Summary results for NUGs are presented in Table 1.3. For tax measures, the reference case for NUGs is the same as that for IOUs in Tables 1.1 and 1.2. Because NUGs are not subject to the ratemaking procedures that IOUs are, CWIP and tax normalization are not applicable and not included in the reference case or any of the scenarios. Also, because the decisionmaking criterion used as the basis for the results presented in Table 1.3 is the internal rate of return (IRR), values greater than 1.00 represent incentives for the technology, while values less than 1.00 are barriers-directly opposite to the interpreiation of Tables 1.1 and 1.2.

With minor exceptions, the taxation barriers and incentives for IOUs in Table 1.1 for property taxes, input taxes, state taxes, and federal taxes are similar to those for NUGs shown in Table 1.3. The main difference between IOUs and NUGs is the effect of the 
Table 1.3

Summary of Tax Effects on Internal Rate of Return, Nonutility Generators

(Ratio of IRR of Case with Taxes to Case Without Taxes )

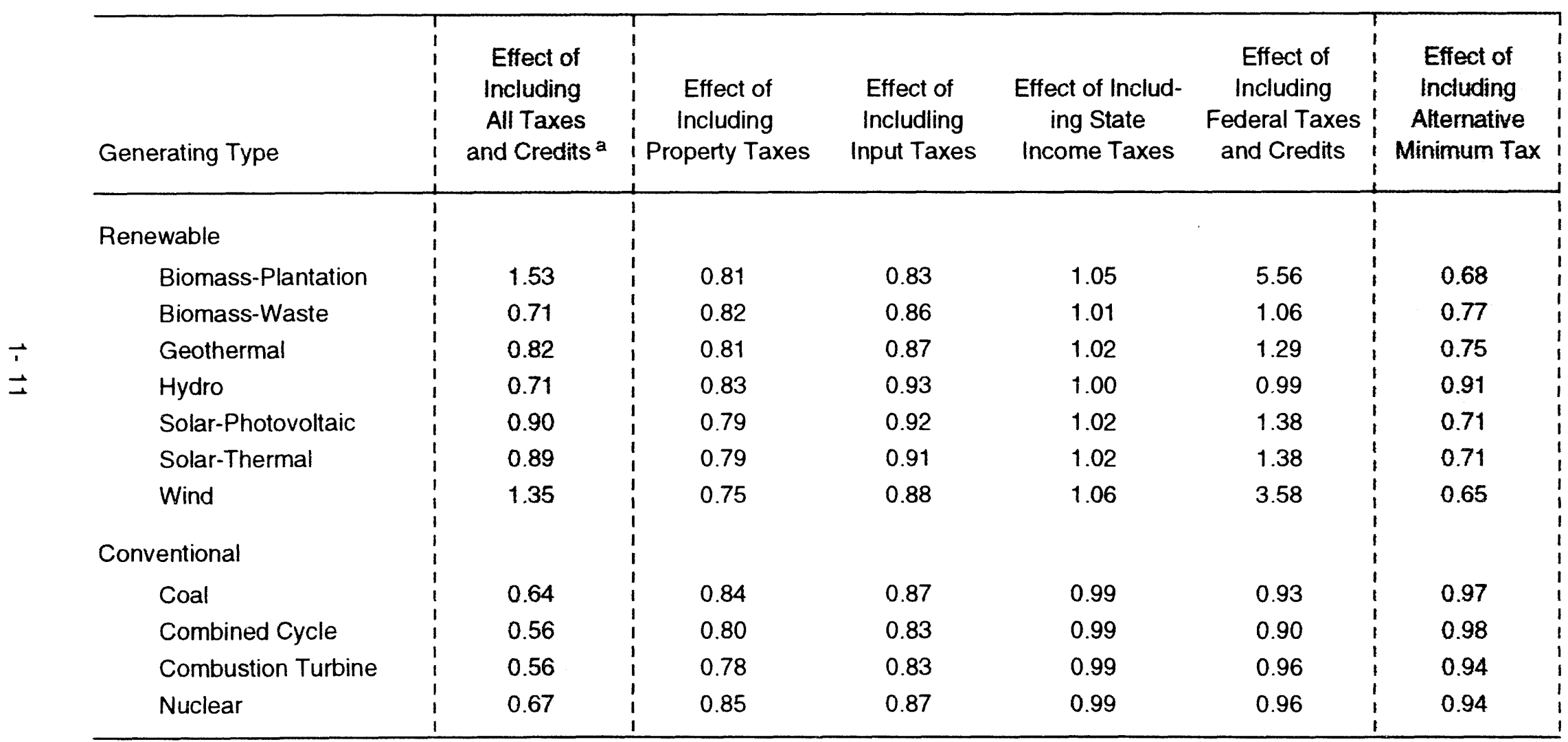

Source: Section 6 in Text

Ratios greater than 1.0 indicate incentives; ratios less than 1.0 indicate barriers.

${ }^{a}$ Because of multiple effects, individual tax effects cannot be summed to obtain the total effect. 
AMT. For noncorporate and corporate entities to which the AMT applies, the AMT is a significant barrier to adoption of all technologies--but primarily renewable technologies which benefit to a larger extent than conventional ones from certain provisions of the federal tax code. From Table 1.3, the federal income tax and its special provisions increase the IRR for dedicated-plantation biomass systems by more than 400 percent from the reference case. If the corporate entity building the plant were subject to the AMT, however, those federal tax advantages would be totally lost.

\subsubsection{Barriers To and Incentives For Renewable Technologies}

The ratios in Tables 1.1 through 1.3 indicate how tax measures and ratemaking procedures affect the decisionmaking criteria used by IOUs and NUGs in evaluating individual technologies. We use that data in this section to determine the types of taxes and ratemaking procedures that are barriers to or incentives for renewable technologies compared to conventional ones. Concisely, a tax or rate procedure is an incentive for the adoption of a renewable technology by IOUs if its ratio in Table 1.1 or 1.2 is more than five percent less than the corresponding average value for all conventional ones. It is a barrier if the ratio is more than five percent greater. For NUGs, the direction of change from the average value of conventionals is reversed for barriers and incentives. This is discussed in greater detail in Section 7.3.

The results on barriers and incentives for renewable technologies are summarized in Tables 1.4 and 1.5 for IOUs and NUGs, respectively. The results show that tax measures and ratemaking procedures are both barriers and incentives, depending on the measure or procedure and whether the decisionmaker is an IOU or a NUG. More specifically, five important conclusions emerge from the data in Tables 1.4 and 1.5.

First, certain federal income tax laws provide incentives for IOUs to invest in most renewable technologies. Short tax depreciation lives provide incentives for solar, wind, and geothermal technologies. Additional incentives are provided by the investment tax credit for solar and geothermal technologies and a $1.5 \mathrm{c} / \mathrm{kWh}$ production tax credit for dedicated-plantation biomass and wind technologies.

Second, short tax depreciation lives, the investment tax credit, and the production tax credit also provide incentives to a NUG to adopt renewable technologies if the NUG is not subject to the alternative minimum tax (AMT).

Third, if a NUG is subject to the AMT, the NUG is not able to take full advantage of the federal tax incentives for renewables and, inerefore, the federal tax laws become a barrier to the adoption of these technologies.

Fourth, local property taxes are barriers to the adoption of capital-intensive renewable technologies. This conclusion is robust under different assumptions about the bases used for calculating property taxes.

Fifth, for the ratemaking procedures for IOUs that we modeled--automatic fuel adjustment clauses vs. adjusting for fuel costs in rate cases, the inclusion in the rate base of construction work in progress (CWIP) vs. the calculation of allowance for funds used 
Table 1.4

Summary of Barriers To and Incentives For Renewable Technologies

Comparison With Conventional Technologies

Investor-Owned Utilities

\begin{tabular}{|c|c|c|c|c|c|c|c|}
\hline $\begin{array}{l}\text { Measure/ } \\
\text { Procedure }\end{array}$ & $\begin{array}{l}\text { Biomass } \\
\text { Plantation }\end{array}$ & $\begin{array}{c}\text { Biomass } \\
\text { Waste }\end{array}$ & Geothermal & Hydro & $\begin{array}{c}\text { Solar } \\
\text { PV }\end{array}$ & $\begin{array}{l}\text { Solar } \\
\text { Thermal }\end{array}$ & Wind \\
\hline
\end{tabular}

\section{Taxation Effects:}

All Taxes

Local Property Taxes

Taxes on Inputs

State Income Taxes

Federal Income Taxes ${ }^{a}$

Accelerated Depreciation ${ }^{b}$

Federal Tax Credits ${ }^{c}$

$\begin{array}{ccc}1 & - & - \\ - & - & - \\ - & - & - \\ i & - & - \\ i & - & 1 \\ i & \text { NA } & \text { NA }\end{array}$

$\begin{array}{cc}B & B \\ B & B \\ - & - \\ \cdot & - \\ -j & 1 \\ \text { NA } & \text { NA }\end{array}$

$\begin{array}{cc}-\dot{1} & \text { B } \\ - & \text { B } \\ \text { i } & \text { i } \\ \text { NA } & \text { i }\end{array}$

\section{Ratemaking Effects:}

No CWIP in the Rate Base

Tax Normalization

Fuel Adjustment Clauses

SOURCE: Table 7.1 in Section 7.3.

$A$ ' $B$ ' indicates that the tax measure or ratemaking procedure is a barrier to adopting the technology based on comparison with conventional technologies. An 'I' indicates that the tax measure or ratemaking procedure is an incentive for adopting the technology based on comparison with conventional technologies. An 'NA' indicates that the measure is not applicable to the technology. An '. ' indicates that the measure or procedure is applicable, but the value of the ratio is within \pm five percent of the average for conventional technologies.

ancludes the effects of all federal income taxes, including accelerated depreciation, and federal production and investment tax credits.

Includes the effects of accelerated depreciation exclusively.

Includes the effects of federal production and investment tax credits exclusively.

during construction (AFUDC), and normalization vs. flowing taxes through the rate base-the automatic fuel adjustment clause and CWIP have minimal effect on the selection of generation resources. Normalization is an incentive for hydro, solar, and wind technologies.

\subsection{REMAINDER OF THE REPORT}

The remainder of the report is divided into six sections with three supporting, 
Table 1.5

Summary of Barriers To and Incentives For Renewable Technologies

Comparison With Conventional Technologies

Nonutility Generators

\begin{tabular}{|c|c|c|c|c|c|c|c|}
\hline $\begin{array}{l}\text { Measure/ } \\
\text { Procedure }\end{array}$ & $\begin{array}{l}\text { Biomass } \\
\text { Plantation }\end{array}$ & $\begin{array}{c}\text { Biomass } \\
\text { Waste }\end{array}$ & Geothermal & Hydro & $\begin{array}{l}\text { Solar } \\
\text { PV }\end{array}$ & $\begin{array}{l}\text { Solar } \\
\text { Thermal }\end{array}$ & Wind \\
\hline All Taxes & I & 1 & 1 & 1 & 1 & 1 & 1 \\
\hline Local Property Taxes & - & - & - & - & - & - & B \\
\hline Taxes on Inputs & - & - & - & 1 & 1 & 1 & - \\
\hline State Income Taxes & 1 & - & - & - & - & - & 1 \\
\hline Federal Income Taxes ${ }^{a}$ & 1 & 1 & 1 & 1 & 1 & 1 & i \\
\hline Accelerated Depreciation & i & i & $i$ & - & $i$ & $i$ & 1 \\
\hline Federal Tax Credits ${ }^{\mathrm{c}}$ & 1 & NA & $i$ & NA & $i$ & $i$ & $i$ \\
\hline Alternative Minimum Tax & B & B & B & B & B & B & B \\
\hline
\end{tabular}

SOURCE: Table 7.2 in Section 7.3.

$A$ ' $B$ ' indicates that the tax measure or ratemaking procedure is a barrier to adopting the technology based on comparison with conventional technologies. An ' $l$ ' indicates that the tax measure or ratemaking procedure is an incentive for adopting the technology based on comparison with conventional technologies. An 'NA' indicates that the measure is not applicable to the technology. An ' $\because$ ' indicates that the measure or procedure is applicable, but the value of the ratio is within \pm five percent of the average for conventional technologies.

Includes the effects of all federal income taxes, including accelerated depreciation, and federal production and investment tax credits.

bincludes the effects of accelerated depreciation exclusively.

Includes the effects of federal production and investment tax credits exclusively.

dincludes the effects of the alternative minimum tax.

technical appendices. In Section 2, we discuss differences between individual project analysis of the type conducted in this study and system-wide, electric-utility planning. Integrated resource planning is seen as the latest method in the evolution of electricutility planning. In Section 3, we quantify the technical cost and engineering parameters of the seven renewable and four conventional electric generating technologies considered in the study, along with the time path of construction expenditures for those technologies and assumptions about the real cost of fuel.

In Sections 4 through 6, we present the detailed results of the study. In Section 4 , the simulation scenarios are defined in the context of existing taxation procedures for IOUs and NUGs and ratemaking procedures for IOUs. Actual simulation results and their 
interpretation for IOUs and NUGs are presented in Sections 5 and 6, respectively. A summary of all of the results is followed by a discussion of the key findings.

A synthesis of the study and its conclusions are presented in Section 7. In this section, we determine the taxation and ratemaking barriers and incentives for adopting renewable technologies compared to conventional ones and place those results in the context of the process of electric-utility decisionmaking, risk, and public policy toward conventional and renewable technologies.

In Appendices A, B, and C, we provide technical details on both inputs and outputs of the study. The model used to simulate the taxation and ratemaking scenarios is described in Appendix $A$. Results of all the simulations are provided in more detail in Appendix B. The raw data used to determine whether or not a tax or ratemaking procedure is a relative barrier to or incentive for renewable technologies are presented in Appendix $\mathbf{C}$. 



\section{DECISIONMAKING CRITERIA AND RESOURCE SELECTION}

\subsection{INDIVIDUAL PROJECT ANALYSIS}

In this study, conventional and renewable technologies were evaluated individually. Values were assigned to key parameters (to be discussed in Section 3) with no interaction allowed between generating alternatives. Therefore, the amount of time that the technologies are used during the course of a year (i.e., their capacity factors) are not based on system optimization, but were predetermined and provided from published sources. For example, the relative costs of fuel inputs did not determine if a technology should be adopted or the amount of time it was used during a year. Rather, the running rate was determined exogenously.

\subsection{SYSTEM PLANNING}

In real-world electric-utility planning, of course, much more sophisticated techniques are used to evaluate electric generating alternatives. Historically, capacity expansion modeling has allowed utilities to trade off technology characteristics based on peak-load projections, projected load duration curves, fuel price forecasts, and other characteristics of their power delivery systems. The degree of sophistication depends on the goals and resources of the utility. An approach that has the capability to

- determine an optimal mix of resources,

- characterize demand for 8,760 hours in every year of the planning horizon,

- determine the variable costs of employing supply-side resources,

- simulate the financial performance of the utility, and

- include uncertainties in resource selection

tends to be very large and complex with significant data requirements.

Therefore, the alternatives were evaluated under "laboratory conditions." That is, no attempt was made to emulate a utility's entire planning process. That process would normally include uncertainty and financial analyses of the type discussed above in addition to the 'screening curve' approach used in this study. If uncertainty and financial analyses were conducted, it could lead to final resource portfolios different from those suggested by the analysis here.

\subsection{EFFECTS OF INTEGRATED RESOURCE PLANNING}

The integrated resource planning (IRP) process complicates utility planning even more. In the IRP process, demand-side management (DSM) resources are placed on an equal footing with both conventional and renewable electric generating alternatives. The process is complicated by the different fundamental characteristics of demand and supply resources because they have different economic and reliability attributes. For example, DSM programs such as those used for load management during peak summer months are not available throughout the course of a year and do not have the same reliability characteristics as renewable and conventional generating alternatives. 
The importance of IRP in the selection of resources by electric utilities is that utilities now have more options to choose from, more alternatives 'competing' to satisfy projected load and energy requirements. By all accounts, the process is expected to result in the selection of more DSM resources--at the expense of renewable and conventional supply. It is expected, for example, that DSM resources will provide as much as 30 percent of the incremental capacity needs from 1990 to 2000 in the United States (Schweitzer, Hirst, and Hill, 1991).

In some IRP processes, renewable options can compete with conventional options better using decisionmaking criteria other than revenue requirements. For example, some states require a societal test in IRP that requires utilities to look at the total cost of providing the electricity service, including environmental costs. To the extent that renewable options result in less harmful environmental emissions than conventional generating alternatives, their chances of adoption are improved using the societal test. 


\section{GENER ^TING ALTERNATIVES}

\subsection{OVERVIEW}

In Tables 3.1 through 3.3, we summarize the financial and technology assumptions used to characterize the seven renewable and four conventional technologies. The primary sources of information for the data in these tables were a recent study of renewable technologies commissioned by the National Association of Regulatory Utility Commissioners (Hamrin and Rader, 1993), the Assumptions for the Annual Energy Outlook 1993 (Energy Information Administration, 1993) and the Electric Power Research Institute's Technical Assessment Guide on electricity supply options (EPRI, 1989). Other sources cross-checked for consistency are listed in Table 3.1. The data were also checked for consistency with the assumptions underlying the National Energy Strategy (DOE, 1991/1992).

Two biomass technologies are considered because of provisions of the Energy Policy Act of 1992. Under that legislation, closed-loop biomass systems, in which tree plantations are dedicated to produce feedstock for boilers, are eligible for a $\$ 0.015 / \mathrm{kWh}$ production incentive if certain conditions are met. Waste-wood biomass systems are not eligible for the credit. Other types of technologies are generally representative of typical power system construction. For most technologies, the region is the Midwest. However, for some renewable technologies such as solar and geothermal, the western part of the United States is applicable. Renewable and conventional technologies are described in greater detail in Sections 3.2 and 3.3, respectively.

The capacities included for each of the technologies are representative of what would currently be constructed, consistent with information available on characteristics of the technology. For renewable technologies, capacities were generally taken from Hamrin and Rader (1993) consistent with the corresponding construction periods provided by EPRI (1989). For conventional technologies, capacities were also based on EPRI (1989) assumptions.

The assumed usage or capacity factors for renewable alternatives are based on data provided by Hamrin and Rader (1993), cross-referenced with the sources listed in Table 3.1. Therefore, given the data in Table 3.1, the only base-load renewable alternatives are biomass and geothermal plants with capacity factors of 70 percent or greater. The hydro alternative chosen for consideration here with a 45 percent capacity factor performs an intermediate duty in the load order. The capacity factors chosen for the conventional alternatives reflect their assumed load duties and are consistent with their relative capital and operating costs. For example, the combustion turbine option has a capacity factor of 10 percent and is used for peaking purposes, consistent with its relatively low capital cost. The combined cycle unit with a 30-percent capacity factor is an intermediate unit, while the coal and nuclear units are used for base-load purposes. The capacity factors for conventional alternatives are generally the ones used for planning purposes (EIA, 1993a; DOE, 1991/1992; and EPRI, 1989).

The total amount of time to construct each of the generating alternatives was taken from EPRI (1989). The total amount consists of a 'preconstruction, licensing, 
Table 3.1

Cost and Engineering Assumptions

Renewable and Conventional Generating Alternatives

\begin{tabular}{|c|c|c|c|c|c|c|c|c|c|}
\hline \multirow[b]{2}{*}{$\begin{array}{l}\text { Generating } \\
\text { Type }\end{array}$} & \multicolumn{5}{|c|}{ Plant } & \multicolumn{2}{|c|}{ Fuel } & \multicolumn{2}{|c|}{ O\&M Costs" } \\
\hline & $\begin{array}{c}\text { Heat Rate } \\
\text { (Btu/kWh) }\end{array}$ & $\begin{array}{l}\text { Capacity } \\
\text { (MW) }\end{array}$ & $\begin{array}{c}\text { Usage }^{b} \\
(\%)\end{array}$ & $\begin{array}{c}\text { Construct }^{\mathrm{c}} \\
\text { (Years) }\end{array}$ & $\begin{array}{l}\operatorname{Cost}^{d} \\
(\$ / k W)\end{array}$ & Type & $\begin{array}{l}\operatorname{Cost}^{e} \\
(\$ / M W h)\end{array}$ & $\begin{array}{c}\text { Variable } \\
\text { (\$/MWh) }\end{array}$ & $\begin{array}{l}\text { Fixed } \\
(\$ / \mathrm{kW})\end{array}$ \\
\hline
\end{tabular}

Renewable

$\begin{array}{lrrrrrrrrr}\text { Biomass-Plantation } & 13,648 & 50 & 70 & 4 & 1,570 & \text { Wood } & 37.53 & 9.00 & 1 \\ \text { Biomass-Waste } & 13,648 & 50 & 70 & 4 & 1,570 & \text { Wood } & 27.30 & 9.00 & 1 \\ \text { Geothermal } & \text { NA } & 60 & 81 & 4 & 2,400 & \text { NA } & \text { NA } & 10.00 & 150.00 \\ \text { Hydro } & \text { NA } & 100 & 45 & 6 & 1,067 & \text { NA } & \text { NA } & 2.00 & 6.40 \\ \text { Solar-Photovoltaic } & \text { NA } & 5 & 22 & 2 & 7,200 & \text { NA } & \text { NA } & 5.00 & 1 \\ \text { Solar-Thermal } & \text { NA } & 80 & 20 & 2 & 2,885 & \text { NA } & \text { NA } & 22.60 & 1 \\ \text { Wind } & \text { NA } & 50 & 30 & 2 & 1,070 & \text { NA } & \text { NA } & 10.00 & 1\end{array}$

Conventional

\begin{tabular}{|c|c|c|c|c|c|c|c|c|c|}
\hline Coal & 10,060 & 300 & 65 & 6 & 1,512 & Coal & 14.60 & 7.00 & $\begin{array}{r}30.30 \\
8.40\end{array}$ \\
\hline Combined Cycle & 8,140 & 120 & 30 & 4 & 590 & Gas & 19.40 & 2.20 & 8.40 \\
\hline Combustion Turbine & 13,100 & 80 & 10 & 2 & 342 & Gas & 31.20 & 5.00 & 0.50 \\
\hline Nuclear & 10,530 & 1,300 & 70 & 7 & 1,548 & Uran & 4.80 & 15.00 & 65.00 \\
\hline
\end{tabular}

SOURCES: Energy Information Administration (1993); Hamrin and Rader (1993); Electric Power Research Institute (1992); Palmerini (1993); National Renewable Energy Laboratory (1990); DeLaquil et al. (1993); American Solar Energy Society (1992); and Department of Energy (1991/1992).

NA - Not Applicable. 


\section{Table 3.1 (Cont.)}

Footnotes

${ }^{a}$ Excluding fuel costs.

${ }^{b}$ Capacity factor--i.e., the portion of the annual maximum number of hours (i.e., 8,760 ) that the plant is used. The assumed capacity factors are the ones used for the National Energy Sirategy (DOE, 1991/1992).

'The number of years that it takes to construct the plant. The portion of total expenditures for each year is presented in Table 2. Data for coal, combined cycle, combustion turbine, and hydro generating plant types is that used for the Annual Energy Outlook, 1993 (EIA, $\dot{\omega}$ 1993). Data for other generating types were obtained from multiple sources, including phone conversations with industry experts.

¿Overnight construction costs. Data were obtained from multiple sources including EIA (1993), Hamrin and Rader (1993), and ASES.

The cost of fuel in 1991. The assumed growth in fuel prices is presented in Table 3.3 and was obtained from the Annual Energy Outlook, 1993 (EIA, 1993).

'Included in the cost of the plant. 
Table 3.2

Construction Expenditures

Renewable and Conventional Generating Alternatives

\begin{tabular}{|c|c|c|c|c|c|c|c|c|c|c|}
\hline & \multicolumn{6}{|c|}{ Renewable Generating Alternatives } & \multicolumn{4}{|c|}{ Conventional Generating Alternatives } \\
\hline & Biomass $^{a}$ & Geothml & Hydro & $\begin{array}{l}\text { Solar } \\
\text { Therm }\end{array}$ & $\begin{array}{l}\text { Solar } \\
\text { PV }\end{array}$ & Wind & $\begin{array}{r}\text { Coal } \\
\text { Steam }\end{array}$ & $\begin{array}{l}\text { Comb. } \\
\text { Cycle }\end{array}$ & $\begin{array}{l}\text { Comb. } \\
\text { Turbine }\end{array}$ & Nuclear \\
\hline $\begin{array}{l}\text { Capacity (MW) } \\
\text { Construction Cost (1991 \$Million) }^{\mathrm{b}}\end{array}$ & $\begin{array}{r}50 \\
78.5\end{array}$ & $\begin{array}{r}60 \\
144.0\end{array}$ & $\begin{array}{r}100 \\
106.7\end{array}$ & $\begin{array}{r}80 \\
230.8\end{array}$ & $\begin{array}{r}5 \\
36.0\end{array}$ & $\begin{array}{r}50 \\
53.5\end{array}$ & $\begin{array}{r}300 \\
453.6\end{array}$ & $\begin{array}{r}120 \\
70.8\end{array}$ & $\begin{array}{r}80 \\
27.4\end{array}$ & $\begin{array}{r}1,300 \\
2,012.4\end{array}$ \\
\hline \multicolumn{11}{|l|}{$\begin{array}{l}\text { Construction Expenditures (\%) } \\
\text { (Years before coming on line) }\end{array}$} \\
\hline 1 & 38 & 38 & 20 & 75 & 75 & 75 & 20 & 38 & 75 & 8 \\
\hline 2 & 37 & 37 & 25 & 25 & 25 & 25 & 25 & 37 & 25 & 15 \\
\hline 3 & 13 & 13 & 30 & & & & 30 & 13 & & 30 \\
\hline 4 & 12 & 12 & 13 & & & & 13 & 12 & & 30 \\
\hline 5 & & & 9 & & & & 9 & & & 15 \\
\hline 6 & & & 3 & & & & 3 & & & 1 \\
\hline 7 & & & & & & & & & & 1 \\
\hline Total & 100 & 100 & 10 & & 100 & 100 & 100 & 100 & 100 & 100 \\
\hline
\end{tabular}

SOURCES: Table 1, Electric Power Research Institute (1989), and Energy Information Administration (1993).

The amounts are the same for plants that use both dedicated plantations and waste wood.

'Overnight costs. 
Table 3.3

Assumed Growth in Fuel Prices

1993-2022

\begin{tabular}{lccccc}
\hline Period & Coal & $\begin{array}{c}\text { Natural } \\
\text { Gas }\end{array}$ & $\begin{array}{c}\text { Nuclear } \\
\text { Fuel }\end{array}$ & Wiomass & Waste Plantation \\
\hline $\begin{array}{l}\text { Fuel Price Amounts: } \\
\text { ( } \$ 1991 \text { per MMBtu) }\end{array}$ & 1.45 & 2.38 & 1.41 & 2.00 & 2.75 \\
$\begin{array}{l}1991 \\
\begin{array}{l}\text { Growth in Fuel Prices: } \\
\text { (Average annual \% growth rates) }\end{array}\end{array}$ & & & & & \\
$1992-2021$ & 1.3 & 3.2 & 0.0 & $1.0^{\mathrm{a}}$ & 0.0 \\
\hline
\end{tabular}

SOURCE: Calculated from Energy Information Administration (1993).

"Assumed to grow at $1.0 \%$ per year for the first 10 years.

and design' period and an 'idealized' plant construction time. For the renewable technologies and coal, combined-cycle, and combustion-turbine alternatives, the number of years in each of these phases were evenly divided. For the nuclear alternative, the idealized plant construction time was five years. The time stream of expenditures in percentage terms for those construction periods are provided in Table 3.2. Where possible, an attempt was made to make the time streams consistent with those used by EIA in producing the Annual Energy Outlook (EIA, 1993). However, construction expenditures are site- and region-specific. To show that our conclusions are invariant to assumptions about the time stream of construction expenditures, sensitivity analyses were performed for some of the technologies. The results of these analyses are presented in Section 5.4.

The capital and operating costs in 1991 dollars for renewable alternatives were generally taken from Hamrin and Rader (1993). The amounts were cross-referenced for consistency with the other sources listed in Table 3.1. The current capital and operating costs for conventional alternatives are the same as those used by EIA in the Annual Energy Outlook (EIA, 1993). Fossil and nuclear fuel costs and their projected growth over the next 30 years (Table 3.3) are based on forecasts in the Annual Energy Outlook (EIA, 1993). Plantation and waste-wood fuel costs are based on Hamrin and Rader (1993), cross-referenced with EPRI (1992). 


\subsection{RENEWABLE ALTERNATIVES}

This section lists key variables and qualifying assumptions for each of the renewable technologies. There is no single source of information that provides point estimates for all of the variables required for this study. However, a recent study completed by Hamrin and Rader (1993) is relatively comprehensive and was chosen as the source for most of the plant and cost level data. Where Hamrin and Rader provide interval estimates for key variables, studies by the American Solar Energy Society (1992), Johansson et al. (1993), DOE (1992), and NREL (1990) are used to reduce the Hamrin and Rader range to a point estimate and/or to provide a verification. As with all studies that provide information on a wide range of technologies, the basic information are abstracted from secondary literature sources and existing studies. Although there may be slight inconsistencies among underlying assumptions given the differing sources of information, these inconsistencies are considered minor relative to the uncertainties inherent in the estimates of capital, fuel, and operating costs. For all technologies listed below, cost data are reported in constant 1991 dollars.

\subsubsection{Biomass}

The data are for a conventional steam-turbine (spreader-stoker) operating at a net efficiency of about $25 \%$. Plant, fuel, and operating data are derived from Hamrin and Rader (1993). Their estimate of the installed capital cost for the plant is higher than an estimate provided by USDOE (1992). The USDOE estimate $(\$ 1366 / \mathrm{kW})$ is about $\$ 200 / \mathrm{kW}$ less. However, Hamrin and Rader report lower non-fuel operating costs $(\$ 0.009 / \mathrm{kWh}$ versus $\$ 0.0135 / \mathrm{kWh})$. Both of these sources are consistent with the actual installed costs for a similar sized facility using conventional conversion technology. Actual capital costs for the $57 \mathrm{MW}$ McNeil plant (Burlington, VT) were about $\$ 80$ million or $\$ 1410 / \mathrm{kW}$ with annual operating and fuel costs of $\$ 19.6$ million (EPRI, 1992). All report similar capacity factors and fuel costs of $\$ 2.00 / \mathrm{MMBtu}$.

\subsubsection{Geothermal}

The geothermal plant is assumed to use a hydrothermal system (geopressured, hot dry rock, and magma systems, which may offer more promise, are not technologically mature). The costs for hydrothermal systems vary widely and are a function of the resource (dominated by water or steam), the amount of drilling and depth, the productivity per well, the type of gathering system required, and the required environmental controls (reinjection of fluids). Palmerini (1993) reports electricity costs ranging from a low of about $\$ 0.03 / \mathrm{kWh}$ to over $\$ 0.10 / \mathrm{kWh}$ (Palmerini, 1993). Hamrin and Rader (1993) cite capital costs from $\$ 2400$ to $\$ 3100 / \mathrm{kW}$. The Interlaboratory White Paper reports capital costs at $\$ 1800 / \mathrm{kW}$ in 1989 dollars (NREL, 1990). Using the mean of data (well depth, well productivity, etc.) contained in Palmerini implies costs toward the lower end of the $\$ 2400$ to $\$ 3100 / \mathrm{kW}$ range. Capital costs were therefore assumed to be at the lower end of the cost interval provided by Hamrin and Rader-- $\$ 2400 / \mathrm{kW}$, including all net costs of drilling. All other data are taken directly from Hamrin and Rader. 


\subsubsection{Hydroelectric}

The hydro technology is assumed to be run-of-the-river utilizing off-the-shelf equipment. The costs of hydro projects are highly site dependent and will vary with topography (e.g., civil works), resource conditions (head and flow), distance to nearest transmission line, and the extent of environmental mitigation (e.g., fish passage facilities) measures that may be required. There are no fuel costs with the operation of a hydro facility. Nori-fuel O\&M costs tend to be low. However, these costs can increase if the facility is required to provide minimum fish flows that result in lost generation, to maintain some threshold dissolved oxygen level, and to operate fish passage facilities. The cost and plant information are derived from Hamrin and Rader. Hamrin and Rader apparently derived their data from the Interlaboratory White Paper, which uses information from a 1986 DOE/EIA report. Hamrin and Rader estimate was inflated to 1991 dollars.

\subsubsection{Solar Thermal}

The solar thermal application is based on parabolic trough technology. (Solar thermal systems relying on central receivers and parabolic dishes have not been commercialized). The only commercial solar thermal system in use is manufactured by Luz. This system uses natural gas as a baskup system. The natural gas backup allows electricity to be sold as firm power during peak load periods. Hamrin and Rader report costs of $\$ 3500 / \mathrm{kW}$ with the natural gas backup. Capital costs without the natural gas backup are reported by ASES at $\$ 2885 / \mathrm{kW}$ with O\&M costs of about $\$ 0.022$ to $\$ 0.03 / \mathrm{kWh}$. The ASES data are also consistent with those found in DeLaquil et al. (1993) $--\$ 2800-\$ 3500 / \mathrm{kW}$ capital and $\$ 0.018-\$ 0.025 / \mathrm{kWh}$. In this application, the ASES estimate was used.

\subsubsection{Solar Photovoltaic}

Photovoltaic systems are generally cost effective sources of power for remote and stand-alone applications as well as for a variety of consumer products. Capital costs are relatively high. Hamrin and Rader provide a total installed capital cost range of $\$ 6200$ to $\$ 9000 / \mathrm{kW}$. This estimate includes all balance-of-system components. A point estimate is provided by the ASES at $\$ 7200 / \mathrm{kW}$. Both sources report O\&M costs at about $\$ 0.005 / \mathrm{kWh}$.

\subsubsection{Wind}

Plant and cost data for a utility-scale wind farm is derived in part from ASES (1992) and Hamrin and Rader (1993). The wind farm is assumed to consist of 250 turbines with each having a rated power output of $200 \mathrm{~kW}$. The installed capital costs for a wind farm are estimated to range between $\$ 1000$ and $\$ 1200 / \mathrm{kW}$ (Hamrin and Rader). ASES estimates total capital costs at $\$ 1070 / \mathrm{kW}$. O\&M costs are placed at from $\$ 0.01$ to $\$ 0.015 / \mathrm{kWh}$ by Hamrin and Rader and slightly less than $\$ 0.01 / \mathrm{kWh}$ by ASES. Capacity factors for wind systems range between $25 \%$ and $30 \%$. 


\subsection{CONVENTIONAL ALTERNATIVES}

In contrast to the renewable alternatives (with the exception of hydro), many more conventional plants exist with years of operating experience and, therefore, much more information and data on their operating characteristics. For the study, we tried to select 'representative' plant types. For the coal alternative, for example, we selected a plant that would likely operate in the midwestern portion of the country.

\subsubsection{Coal}

The data in Table 3.1 represent a 300-MW, coal-fired steam unit with flue gas desulfurization (FGD). The unit is assumed to burn Illinois bituminous, high-sulfur coal and is located in the East/West Central portion of the country. The major components of the plant include coal-handling equipment, steam-generator island, turbine-generator island, FGD system, bottom and fly ash handling system, and the stack. The FGD system achieves $90 \% \mathrm{SO}_{2}$ removal.

\subsubsection{Combined Cycle}

The combined cycle plant is a conventional unit burning natural gas and is used in the East/West Central region of the country. Combustion turbine generators account for two-thirds of the power and one-third comes from a steam turbine generator. A heat recovery system accounting for the steam generation improves the efficiency of the system. $\mathrm{NO}_{x}$ emissions are controlled by injecting water or steam into the combustor. More stringent $\mathrm{NO}_{x}$ emission standards may require selective catalytic reduction.

\subsubsection{Combustion Turbine}

The combustion turbine is a conventional system that would be constructed in the East/West Central portion of the country. The unit consists of an air compressor, a combustor, and an expansion turbine. $\mathrm{NO}_{x}$ emissions are controlled by injecting water or steam into the combustor. Because the power output of a combustion turbine is very sensitive to the ambient temperature, it is assumed that the ambient temperature for the data presented in Table 3.1 is $59^{\circ}$.

\subsubsection{Nuclear}

The data for the nuclear unit are based on current experience for building large, commercial nuclear power plants of U.S. design world-wide. We are basing our analysis on two U.S. advanced boiling water reactor units that are under construction for the Tokyo Electric Power Company at the Kashiwazaki-Kariwa site, and the construction time from first concrete pour to fuel load is expected to be less than four years. Additionally, four U.S. pressurized water reactor units are under construction in Korea and also will be completed in less than four years. For a U.S. application, we assume a five-year construction period and, with passage of EPACT, a two-year licensing period for a total construction and licensing period of seven years (Table 3.2). Nuclear plants in operation in the U.S. are experiencing total O\&M (fixed and variable) costs as low as 8 mills $/ \mathrm{kWh}$, but averaging 15 mills $/ \mathrm{kWh}$; and capacity factors exceeding 90 percent, but averaging 70 
percent. Although it is expected that Advanced Light Water Reactors, to be completed in the next decade, will achieve a lower average O\&M cost and a higher average capacity factor, this study assumes actual experiences to date. 


\section{TAXATION, RATEMAKING, AND DEFINITION OF SCENARIOS}

In this section, we define the scenarios that will be simulated using the financial regulatory model described in Appendix $A$. The scenarios are placed in the context of current taxation and ratemaking policies. That is, each variant from the reference scenario is chosen to reflect departures from existing federal, state, and local tax laws and the application of ratemaking principles in individual states.

The reference scenario is defined in Section 4.1. For IOUs and NUGs, tax scenarios deviating from the reference scenario are defined in Section 4.2. For lOUs exclusively, ratemaking scenarios deviating from the reference scenario are defined in Section 4.3.

\subsection{REFERENCE SCENARIO}

In the reference scenario, we define financial conditions for IOUs and NUGs that come as close as possible to representing the types of conditions that a typical IOU or NUG would confront in the real world, recognizing differences in ratemaking and tax types across the $\mathbf{5 0}$ states. We assume that the typical IOU or NUG is subject to the following:

- $3 \%$ local property taxes,

- sales and payroll taxes on construction and operating expenses

- $6 \%$ state income taxes,

- $35 \%$ federal income tax,

- differences between tax and book depreciation for federal and state income taxes, depending on the type of ownership and the type of technology (defined in Table 4.3),

- federal production tax credits for integrated biomass systems and wind technologies, and

- federal investment tax credits for solar and geothermal technologies.

In addition, for IOUs we assume that (1) no CWIP is allowed in the rate base for ratemaking purposes, (2) all differences between tax provisions for tax and book purposes are 'normalized' in determining rates, and (3) all assumed changes in the real cost of fuels are passed on to the ratepayer in the year in which they are experienced by the utility.

in addition to the tax and ratemaking factors considered above, financial parameters applicable to the utility or NUG are defined to execute the financial regulatory model described in Appendix A. In Table 4.1, we show these parameters for IOUs, along with representative values. In most cases, the title of the input parameter is selfexplanatory. Debt ratio is the percentage of assets financed through debt. This study used constant dollars for its analysis and no inflation. Consequently, average allowed returns on debt and equity were reduced by $4 \%$ points from real world values averaging 
$9 \%$ and $11 \% .^{1}$ Construction and O\&M cost escalation rates were kept at $0 \%$. Fuel escalation rates varied, depending on the type of fuel. Table 3.3 shows the rates used for fuel costs.

Table 4.1

Financial Parameters for Investor-Owned Utilities

\begin{tabular}{lcll}
\hline Pcirameter & Value & Parameter & Value \\
\hline Work Capital \% of O\&M & $12.5 \%$ & CWIP allowed in Rates & \\
Debt Ratio & $50 \%$ & Normalized Tax & Yes \\
Labor Tax Rate & $10 \%$ & Interest Rate & $5.0 \%$ \\
Energy Tax Rate & $5.0 \%$ & Allowed Return on Equity & $7.0 \%$ \\
Material Tax Rate & $5.0 \%$ & Fuel Recover Lag, years & \\
Land Tax Rate & $5.3 \%$ & Fed. Income Tax Rate & $35 \%$ \\
Construction Escalation rate & $a$ & State Income Tax Rate & $6 \%$ \\
O\&M Escalation rate & $a$ & Property Tax Rate & $3.00 \%$ \\
Fuel Escalation rate & $a$ & Property Tax Method & Net Book \\
& & & \\
\hline
\end{tabular}

avalues depend on the specific circumstances of the scenarios that are simulated.

A working capital account was established equal to $12.5 \%$ of the next year's operations and maintenance ccst. This caused the utility to issue additional equity and debt the year before operation and to recover this money in the last year of operation.

Similar financial information for NUGs is presented in Table 4.2. Most financial data is the same as for the IOU reference scenario. Parameters that are different are the sales price, the debt ratio, and flags to use the alternative minimum tax and/or the carry forward of tax losses. The debt ratio was set at $80 \%$ for the NUG scenarios. This reflects the increased use of debt by nnn-utility generators in the construction of their plants.

The sales price is equal to the levelized cost to customers from the reference IOU scenario for each technology. This means that for each technology, as far as customers

\footnotetext{
${ }^{1}$ Relaxing the constant-dollar assumption does not affect the conclusions of the study. Simulation results using current dollars are reported in Section 5.4 .
} 


\section{Table 4.2}

Financial Parameters for Non-Utility Generators

\begin{tabular}{llll}
\hline Parameter & Value & Parameter & Value \\
\hline NUG Sales Price, $/ \mathrm{kWh}$ & & Alternative Minimum Tax & No \\
Debt Ratio & $80 \%$ & Carry Forward Losses & No \\
Labor Tax Rate & $10 \%$ & Interest Rate & $5.0 \%$ \\
Energy Tax Rate & $5.0 \%$ & Work Capital \% of O\&M & $12.5 \%$ \\
Material Tax Rate & $5.0 \%$ & Fed. Income Tax Rate & $35 \%$ \\
Land Tax Rate & $5.3 \%$ & State Income Tax Rate & $6 \%$ \\
Construction Escalation rate & - & Property Tax Rate & $3 \%$ \\
O\&M Escalation rate & - & Property Tax Method & Net Book \\
Fuel Escalation rate & - & & \\
\hline
\end{tabular}

aalues depend on the specific circumstances of the scenarios that are simulated.

are concerned, the cost of either the IOU scenario or NUG scenario are the same. It also makes the utilities relatively indifferent to the ownership. The net effect is to remove the NUG price as a major factor in this analysis.

\subsection{ALTERNATIVE TAX SCENARIOS FOR IOUs AND NUGs}

After the reference scenarios were established, a number of variations on the different tax rates and tax methods were performed. These were done to identify the relative impact of each parameter on the key criteria. By identifying tax parameters that had a significantly different effect on renewables versus conventional technologies, we could identify those which may create a disincentive for one or the other.

Synergies existed among some of the input parameters. Modifying one of the variables amplified the effect of others. To study this in more detail, we ran combined scenarios and measured their results against the scenarios with only one of the parameters altered.

\subsubsection{Effect of All Taxes}

The first variation to the reference case was to run each technology with no taxes 
of any kind. This also meant that tax credits were set at zero.

\subsubsection{Property Tax Effects}

We used a property tax rate of $3 \%$ of the net book value of the plant and equipment, including land, in the reference scenarios. We based this on an analysis of the typical rate charged by states and localities, when adjusted for differences in assessment value used as a percentage of full assessed value. Net book value (gross plant and equipment less depreciation) was used as representative of the market value assessment that would be placed on a plant.

In reality, property taxes vary across the country by wide amounts, depending largely on local tax needs. According to the report from the U.S. Advisory Commission on Intergovernmental Relations, tax rates can vary from less than $1 \%$ to over $10 \%$ in different localities. Generating plants are usually located in rural areas, which tend to have lower property tax rates. However, these plants are often the major source of revenues for local governmental needs such as schools and fire protection.

To understand the effect of different methods for calculating the property tax base we used two other methods, gross book value and the net present value of the future cash flow stream. Also, we studied the effect of charging property tax on the added plant and equipment but not on the original land value.

\subsubsection{Taxes on Construction and Operating Inputs}

The costs that go into building and operating a generating plant often have taxes placed on them. We split capital costs into four categories: labor, energy, material, and land. Labor and material each were assigned between $40 \%$ and $45 \%$ of the capital cost. Energy was assigned $10 \%$ and land $5 \%$. Wind was given a land value of $10 \%$ to reflect the higher land requirement for this technology. We split the O\&M costs between labor and material.

Representative tax rates on the input labor, energy, material, and land were established as shown in Table 4.1. Labor taxes represent such factors as social security and unemployment taxes. The values used are to represent only the company's contribution. Energy, material, and land taxes are based on a $5 \%$ sales tax with an additional $0.3 \%$ deed transfer tax for land. These are based on approximate average values for the states and localities; actual amounts vary widely from $0 \%$ to over $9 \%$. Also, some states exclude businesses from sales tax. For this study, fuel tax rates are assumed to be the same as for other materials going into the plant, but actual taxes on fuel may be based on different parameters.

\subsubsection{State Income Tax Effects}

We set the state income tax to zero to understand its effect on the technologies. Our reference case used an input rate of $6 \%$. Because state taxes are deductible from federal taxes, the net state tax rate in the model for the reference case was about $4 \%$. As 
with property taxes, the actual rates varied across the states from $0 \%$ to more than $10 \%$.

\subsubsection{Federal Income Tax Effects}

To study the effect of income taxes, we set the federal tax rates at zero. The reference case uses a federal tax rate of $35 \%$. In addition, federal tax credits were set to zero as well. This means that the dedicated biomass plant and wind plant did not have the production tax credit and the geothermal and solar technologies did not have the investment tax credit. By zeroing both taxes and credits, we could understand the combined effect of the major federal tax policies. We ran a separate scenario eliminating the credits only (see Section 4.2.7)

\subsubsection{Effects of Federal Tax Depreciation Lives}

Federal tax depreciation law is affected by three asset depreciation systems defined in three different pieces of legislation. The Modified Accelerated Cost Recovery System (MACRS), introduced by the Tax Reform Act of 1986, is mandatory for depreciating most tangible property placed in service after 1986. MACRS substantially changes the Accelerated Cost Recovery System (ACRS) for tangible property placed in service after 1980 and before 1987. ACRS was created as part of the Economic Recovery Tax Act of 1981. Pre-1981 assets are depreciated under provisions of the Revenue Act of 1971 which created the Asset Depreciation Range (ADR) depreciation system. Today, both MACRS and ACRS are related to the ADR system in that property is generally classified by reference to class lives.

Under MACRS, the cost of depreciable pre perty is recoverable over $3,5,7,10,15$, $20,27.5$, or 31.5 years, depending on the type of property through use of statutory recovery methods. Those statutory recovery methods relate a 'class life' as defined in the ADR depreciation system to a recovery period under MACRS. These relationships were defined in two revenue procedures subsequent to enactment of the Tax Reform Act of 1986. In Table 4.3, the recovery periods (i.e., the tax lives) for conventional technologies and hydroelectric are based on the table of MACRS Tax Lives.

Classes of depreciable property are defined by Code Sections 1245 and 1250 property and the class life as of January 1, 1986. The class life of an asset affects its recovery period, the method of depreciation used, and the applicable convention. Under MACRS, five-year property generally includes property with a class life of more than four years and less than ten years. Specifically added to this class are

- geothermal, solar, and wind energy properties; and

- certain biomass properties that are small power production facilities. ${ }^{2}$

The effects of this section of the code are also contained in Table 4.3 for biomass systems operated by non-utility generators (i.e., qualifying facilities in terms of the code),

\footnotetext{
${ }^{2}$ IRS Code Sec 168(e)(3).
} 
Table 4.3

Book and Tax Depreciation Lives

Renewable and Conventional Generating Alternatives

\begin{tabular}{|c|c|c|c|c|c|c|}
\hline \multirow{2}{*}{$\begin{array}{l}\text { Generating } \\
\text { Alternative }\end{array}$} & \multicolumn{3}{|r|}{ Investor-Owned Utilities ${ }^{a}$} & \multicolumn{3}{|r|}{ Non-Utility Generators } \\
\hline & Book & $\operatorname{Tax}$ & Internal Revenue Source & Book & $\operatorname{Tax}$ & Internal Revenue Source \\
\hline \multicolumn{7}{|l|}{ Renewable } \\
\hline Biomass-Plantation & 30 & 20 & Rev. Proc. 88-22, 1988-1 CB 785 & 30 & $5^{b}$ & IRS Code Sec. 168(e)(3) \\
\hline Biomass-Waste & 30 & 20 & Rev. Proc. 88-22, 1988-1 CB 785 & 30 & $5^{b}$ & IRS Code Sec. 168(e)(3) \\
\hline Geothermal & 30 & 5 & IRS Code Sec. 168(e)(3) & 30 & 5 & IRS Code Sec. 168(e)(3) \\
\hline Hydro & 50 & 20 & Rev. Proc. 88-22, 1988-1 CB 785 & 50 & 20 & Rev. Proc. 88-22, 1988-1 CB 785 \\
\hline Solar-Photovoltaic & 30 & 5 & IRS Code Sec. 168(e)(3) & 30 & 5 & IRS Code Sec. 168(e)(3) \\
\hline Solar-Thermal & 30 & 5 & IRS Code Sec. 168(e)(3) & 30 & 5 & IRS Code Sec. 168(e)(3) \\
\hline Wind & 30 & 5 & IRS Code Sec. 168(e)(3) & 30 & 5 & IRS Code Sec. 168(e)(3) \\
\hline \multicolumn{7}{|l|}{ Conventional } \\
\hline Coal & 30 & 20 & Rev. Proc. 88-22, 1988-1 CB 785 & 30 & 20 & Rev. Proc. 88-22, 1988-1 CB 785 \\
\hline Combined Cycle & 30 & 20 & Rev. Proc. 88-22, 1988-1 CB 785 & 30 & 20 & Rev. Proc. 88-22, 1988-1 CB 785 \\
\hline Combustion Turbine & 30 & 15 & Rev. Proc. 88-22, 1988-1 CB 785 & 30 & 15 & Rev. Proc. 88-22, 1988-1 CB 785 \\
\hline Nuclear & 30 & 15 & Rev. Proc. 88-22, 1988-1 CB 785 & 30 & 15 & Rev. Proc. 88-22, 1988-1 CB 785 \\
\hline
\end{tabular}

'For all renewable and conventional technologies, assumes that investor-owned electric utilities 'normalize' book to tax differences in accelerated depreciation for ratemaking purposes.

bOnly available for 'qualifying facilities' under the Federal Power Act, one type of non-utility generator. 
and geothermal, solar, and wind plants operated by investor-owned utilities and nonutility generators.

All of these depreciation provisions under MACAS listed in Table 4.3--and including the ones related to renewable generating technologies--do not pertain to 'public utility property, unless a normalization method of accounting is used. ${ }^{3}$

'Public utility property' that does not qualify under MACRS is depreciated under Code Sec. 167(a) using the same depreciation method and useful life as is used to compute the ratemaking depreciation allowance for the asset.

In the reference scenario, normalization is used for tax accounting. Therefore, all of the favorable tax lives provided by MACRS for both conventional and renewable generating technologies as shown in Table 4.3 are available for both IOUs and NUGs. However, as discussed in Section 4.3.2, a ratemaking scenario deviating from the normalization case is simulated.

Under MACRS, the cost of depreciable property is recovered using (1) the applicable depreciation method, (2) the applicable recovery period, and (3) the applicable convention (Code Section 168(a)). However, instead of the applicable depreciation method, taxpayers may elect to claim straight-line MACRS deductions over the regular recovery period. Additionally,

- the cost of property recovered over $3,5,7$, and 10 years is recovered using the $200 \%$ declining-balance method, the half-year convention, with a switch to the straight-line method in order to maximize the deduction (Code Sec. 168(b)(1))).

- the cost of property recovered over 15 and 20 years is recovered by the $150 \%$ declining balance method, using the half-year convention, with a switch to the straight-line method at a time to maximize the deduction (Code Sec. 168(b)(2)).

In our depreciation accounting, we use the $200 \%$ and $150 \%$ variants as specified in the legislation.

\subsubsection{Effects of Federal Tax Credits}

Provisions of EPACT allow tax credits for the production of electricity using closedloop biomass and wind energy sources (i.e., a production tax credit) and extends the tax credit for investment in solar and geothermal electric generating stations. These credits are available to any taxpayer (i.e., $1 O U$ or NUG) that meets the performance and quality standards of the legislation.

The reference cases included the tax credits available to IOUs and NUGs. The

\footnotetext{
${ }^{3}$ IRS Code Sec. $168(i)(10)$
} 
credits were not allowed in the scenario excluding all taxes (Section 4.2 .1 above), the scenario excluding federal income taxes (Section 4.2.5) and the scenario excluding tax credits.

According to section 1914 of EPACT, a production tax credit of $1.5 \mathrm{c} / \mathrm{kWh}$ is available for wind and closed-loop biomass, with some limitations. The key factor is that the tax is phased-in as the price of electricity generated falls below $11 \mathrm{c} / \mathrm{kWh}$ and reaches the full $1.5 \mathrm{c} / \mathrm{kWh}$ when the price is at or below $8 \mathrm{c} / \mathrm{kWh}$. Also, the credit is available only during the first 10 years of a plant's operation.

Section 1916 of EPACT permanently extends the investment credit (i.e., the energy investment credit) for solar and geothermal property. The credit equals 10 percent of the value of solar and geothermal facilities placed in service. Up until recently, both NUGs and IOUs could take advantage of the ITC. IOUs had to normalize the benefits of the credit over the useful life of the asset to take advantage of the ITC. Recent changes in tax law, however, only allow NUGs to take advantage of the ITC for solar and geothermal property. IOUs are excluded from the benefit.

\subsubsection{Effects of the Alternative Minimum Tax (AMT)}

The AMT was created to ensure that at least a minimum amount of income tax is paid by corporate and high-income non-corporate taxpayers who derive large tax savings from certain provisions of the Code, including favorable tax depreciation provisions under MACRS. All taxpayers whether corporate or non-corporate must make a depreciation adjustment. For property placed in service after 1986, the alternative depreciation system must be used. MACRS deductions are reduced for certain property by requiring that an 'alternative MACRS' method based on generally longer recovery periods be used (Code Sec. $168(\mathrm{~g})$ ). In computing depreciation for AMT purposes, the 'alternative MACRS' must be used with certain modifications.

After taxable income is adjusted by the alternative depreciation amounts, a lower income tax rate of $20 \%$ is applied. If income taxes are higher using the adjusted income and tax rate than taxes under the regular rate using standard MACRS rules, then the corporation must pay the higher tax.

The reference scenarios for the IOUs and NUGs did not have the AMT. It was assumed that the corporations would have sufficient depreciation from older facilities to make the net tax higher under the input $35 \%$ rate. A sensitivity was run for NUGs in which the alternative minimum tax did apply. The model calculates taxes under both the regular MACRS rules and 35\% rate, and using the alternate depreciation schedule and a $20 \%$ rate. The higher of the two taxes in each year is then what was owed to the federal government.

In the reference scenarios tax losses occurred in some years, resulting in a negativo income tax. Supposedly, the government would then pay the company. In actuality, we assume that the corporation (IOU or NUG) would have sufficient positive income from other investments to offset these losses. The "negative taxes" would 
actually be a reduction in the total taxes the corporation would pay that year.

If a corporation does not have offsetting positive taxes, it would either apply these losses to profits made in earlier years (i.e., carry back the losses), or it would carry forward the losses to apply them against profits in a future year. There are limits on how far back or forward a corporation may carry tax losses. We did not model carry-back of losses, but did model the option to carry losses forward a maximum of 15 years. This is because tax losses occur mainly in the early years of operation, so that there are not profits in earlier years to which carry-back can apply.

We only applied this carry-forward of losses scenario to NUGs because they are more likely to be small companies to which the requirement applies.

\subsection{ALTERNATIVE RATEMAKING SCENARIOS FOR IOUS}

\subsubsection{Treatment of Construction Work in Progress}

When state regulatory commissions set rates for utilities in their jurisdiction, they use a set of ratemaking procedures that determine what costs are included for recovery. Appendix $A$ describes the methodology used within this study to simulate the regulatory process. It includes establishing a rate base for which the utility may earn a return on its investment, fuel costs, O\&M costs, taxes, and depreciation. The sum of these provides the amount of required revenues for the modeled project. We assumed that the utility would incorporate this amount with the required revenue from its other operations (not modeled) in determining its overall electricity prices.

If a utility receives no revenue from CWIP in the rate base, it includes an accounting revenue called Allowance for Funds Used During Construction (AFUDC) on its books. This is the amount of return the utility would have earned on the plant each year and is based on the debt and equity rates and cost of capital. This amount gets capitalized on the books as an asset and compounds over time. When the plant starts producing electricity AFUDC is included in the rate base of the plant. It then is depreciated like the other capital costs and recovered in the revenues.

\subsubsection{Normalization vs. Flow-Through Tax Accounting}

If there were no differences between provisions of the tax law and accounting for ratemaking, the question of normalization would not arise. Because of the MACRS depreciation system, however, timing differences arise between ratemaking accounting and tax accounting. That is, expenses are recorded for tax purposes in one year and for book purposes in another. Over a sufficient number of years, these expenditures have the same nominal effect on both financial and tax accounting.

Regulatory commissions historically have used two methods to deal with these differences in ratemaking. First, the utility defers the tax benefits and amortizes them over the useful life of the asset. Or, a charge is made to current operations ('provision for deferred taxes') and a corresponding credit is made to a deferred liability ('reserve for 
deferred taxes'). When the timing difference turns around, the reverse entry is made (i.e., income is credited and the reserve charged.) Under the second method, 'flow-through accounting,' no deferred reserve is created. The current tax benefits are not amortized for ratemaking, but impact rates in the current period.

A similar option exists for the investment tax credit (ITC). The ITC allows utilities a dollar-for-dollar credit against their federal income tax liabilitv for a specified percent of the amount of the investment in a qualified plant. From an accounting standpoint, the ITC represents a permanent savings in taxes rather than a deferral. The key ratemaking question is the year in which tax expense should be reduced for ratemaking purposes.

Like depreciation accounting for timing differences, discussed above, there are two methods used to reflect the impact of ITC for ratemaking purposes. The first method requires a deferral of the credit in the year that it is realized. The amount of the credit is then amortized over the useful life of the property. The second method allows the entire credit to affect book income the year in which the asset is placed in service.

\subsubsection{Fuel Adjustment Clauses}

Regulatory commissions set the level of required revenues based on the expected costs for a future period. Fuel costs are the most volatile of these costs and may be significantly different from what was predicted. Recognizing this, many commissions allow utilities to automatically adjust their rates as fuel costs change without requiring a new rate hearing. This practice protects the utility from the financial risk of absorbing the extra costs if fuel prices increase faster than expected.

In our reference scenario, we capture the effects of a fuel adjustment clause. As an alternative scenario, we modeled a case in which the commission expects that fuel costs would escalate only at the general rate of inflation. Any increase above that would not be recovered until the following year. In a sense, this portrays commissions as less prescient than reality dictates. On the other hand, we use only a single escalation rate for fuel for all years. In the real world, fuel prices would increase at rates both greater and lower than the average value that we used.

Many advocates of renewable technologies argue that passing all fuel price increases on to ratepayers--whether instantaneously or on a lag--represents an incentive for utilities to adopt conventional technologies because fuel costs represent a large portion of the total costs of using conventional technologies. Most renewables do not require fuel and, therefore, are generally more capital-intensive than conventional technologies. Utilities, it is argued, are exposed to more risk from capital-intensive technologies because of the danger that commissions may disallow a portion of capital expenditures in the rate base as a result of prudency reviews.

To see the effects of disallowing a portion of fuel price increases to be passed along to ratepayers, we conducted a sensitivity analysis. The results of that analysis are presented in Section 5.4 along with other sensitivity results. 


\section{SIMULATION RESULTS FOR INVESTOR-OWNED UTILITIES}

\subsection{SUMMARY}

In Table 5.1, we compare the results of different tax measures with the reference case. As in Table 1.1, the results in Table 5.1 reflect the ratio of the reference case-which includes a $35 \%$ federal tax on income, accelerated tax depreciation, and federal production tax credits-to a scenario that does not include the subject tax, depreciation, or credit. The results in Table 5.1, unlike those in Table 1.1, also include the second decisionmaking criterion for IOUs: the internal rate of return (IRR). For levelized costs, values greater than 1 indicate increases in cost and therefore barriers to adopting the technologies. The reverse is true for values less than 1. Conversely, for IRR, values greater than 1 indicate increases in IRR and are therefore incentives to adopting the technology. The reverse is true for values less than 1.

The value of 1 for the reference case of each technology and decisionmaking criterion reflects the ratio of values of the simulation results for levelized cost and IRR to themselves. For information purposes, we show the breakdown of costs for the reference cases of each technology in Fig. 5.1. The cost components sum to $100 \%$. The negative components below the $0 \%$ indicator offset the costs above the $100 \%$ line. Because the levelized cost calculation is based on required revenues from the rate base, the capital costs include both depreciation and return on investment. The characterization of technologies in Fig. 5.1 indicates the relative capital intensity of each of the technologies adopted by a "representative" utility without quantifying the levelized costs of those technologies. The figure shows the relatively higher capital intensity of the renewable technologies in comparison with conventional ones. This observation will be important later in interpreting the results of many of the scenarios.

In Table 5.1, in the first scenario we show the effects of all taxes and credits-local, state, and federal-on levelized cost and IRR. The results for the levelized costs of all the technologies are depicted in Fig. 5.2. For conventional technologies, all taxes raise costs by approximately $20 \%$. For renewable technologies, on the other hand, the simulations indicate a more varied response to taxes. While most renewables show effects from taxes similar to or higher than the effects for conventional technologies, the levelized costs of dedicated biomass and wind plants decrease when taxes are imposed. To see why, we analyzed the effects of each tax measure.

The effects of property taxes shown in Table 5.1 indicate the relatively higher capital-intensity of renewable technologies (especially hydro, solar, and wind) compared with conventional ones, with cost increases on the order of $20-30 \%$. This is discussed in more detail in Sect. 5.2.2.

As Table 5.1 shows, input taxes (on labor, fuel, material, and land) increase costs approximately $7 \%$. The effects of the different input taxes are discussed in more detail in Sect. 5.2.3. 
Table 5.1

Summary of Tax Effects on Levelized Cost and Internal Rate of Return,
Investor-Owned Utilities
(Ratio of Case With Taxes to Case Without)

\begin{tabular}{|c|c|c|c|c|c|}
\hline Generating Type & $\begin{array}{l}\text { Effect of } \\
\text { Including } \\
\text { All Taxes } \\
\text { and Credits }\end{array}$ & $\begin{array}{l}\text { Effect of } \\
\text { Including } \\
\text { Property Taxes }\end{array}$ & $\begin{array}{l}\text { Effect of } \\
\text { Including } \\
\text { Input Taxes }\end{array}$ & $\begin{array}{c}\text { Effect of Includ- } \\
\text { ing State } \\
\text { Income Taxes }\end{array}$ & $\begin{array}{l}\text { Effect of } \\
\text { Including } \\
\text { Federal Taxes } \\
\text { and Crodits }\end{array}$ \\
\hline AENEWABLES & 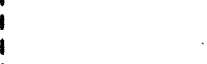 & $i$ & & & \\
\hline Biomass-Plantation & & i & & & \\
\hline Levelized Cost & 0.97 & 1.09 & 1.07 & 0.99 & 0.85 \\
\hline Int. Rate of Return & 0.99 & 1.00 & 1.00 & 1.00 & 0.99 \\
\hline Biomass-Waste & 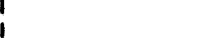 & $i$ & & & \\
\hline Levelized Cost & 1.19 & 1.08 & 1.06 & 1.01 & 1.03 \\
\hline Int. Rate of Return ? & 0.99 & 1.00 & 1.00 & 1.00 & 0.99 \\
\hline Geothermal & 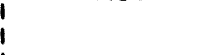 & $i$ & & & \\
\hline Levelized Cost & 1.16 & 1.11 & 1.07 & 1.00 & 0.98 \\
\hline Int. Rate of Return ! & 0.95 & 1.00 & 1.00 & 0.99 & 0.96 \\
\hline Hydro & 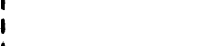 & $i$ & & & \\
\hline Levelized Cost & 1.40 & 1.24 & 1.07 & 1.01 & 1.04 \\
\hline Int. Rate of Return ! & 0.98 & 1.00 & 1.00 & 1.00 & 0.98 \\
\hline Solar-Photovoltaic & 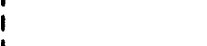 & 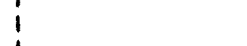 & & & \\
\hline Levelized Cost & 1.27 & 1.27 & 1.07 & 0.99 & 0.95 \\
\hline Int. Rate of Return! & 0.94 & 1.00 & 1.00 & 0.99 & 0.95 \\
\hline Solar-Thermal & $i$ & $i$ & & & \\
\hline Levelized Cost & 1.24 & 1.23 & 1.07 & 0.99 & 0.95 \\
\hline Int. Rate of Return! & 0.94 & 1.00 & 1.00 & 0.99 & 0.95 \\
\hline Wind & 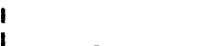 & $i$ & & & \\
\hline Levelized Cost & 0.91 & 1.31 & 1.10 & 0.97 & 0.71 \\
\hline Int. Rate of Return ? & 0.95 & 1.00 & 1.00 & 0.99 & 0.95 \\
\hline CONVENTIONALS & $i$ & 1 & & & \\
\hline Coal & $\vdots$ & $i$ & & & \\
\hline Levelized Cost & 1.22 & 1.09 & 1.07 & 1.01 & 1.04 \\
\hline Int. Rate of Return I & 0.99 & 1.00 & 1.00 & 1.00 & 0.99 \\
\hline Combined Cycle & i & $i$ & & & \\
\hline Levelized Cost & 1.18 & 1.07 & 1.06 & 1.00 & 1.03 \\
\hline Int. Rate of Return ! & 0.99 & 1.00 & 1.00 & 1.00 & 0.99 \\
\hline Combustion Turbine & $\begin{array}{l}1 \\
\vdots\end{array}$ & $i$ & & & \\
\hline Levelized Cost & 1.18 & 1.09 & 1.06 & 1.00 & 1.02 \\
\hline Int. Rate of Return ! & 0.98 & 1.00 & 1.00 & 1.00 & 0.98 \\
\hline Nuclear & i & i & & & \\
\hline Levelized Cost & 1.20 & 1.09 & 1.07 & 1.00 & 1.03 \\
\hline Int. Rate of Return ? & 0.98 & 1.00 & 1.00 & 1.00 & 0.98 \\
\hline
\end{tabular}

Note: The tax effects are the ratios of the levelized costs and IRRs of the cases with taxes to the cases without the taxes. Levelized cost ratios greater than 1.0 indicate barriers; ratios less than 1.0 indicate incentives. IRR ratios greater than 1.0 indicate incentives; ratios less than 1.0 indicate barriers. 
Figure 5.1

Levelized Cost Components for Each Technology, IOU Reference Scenarios

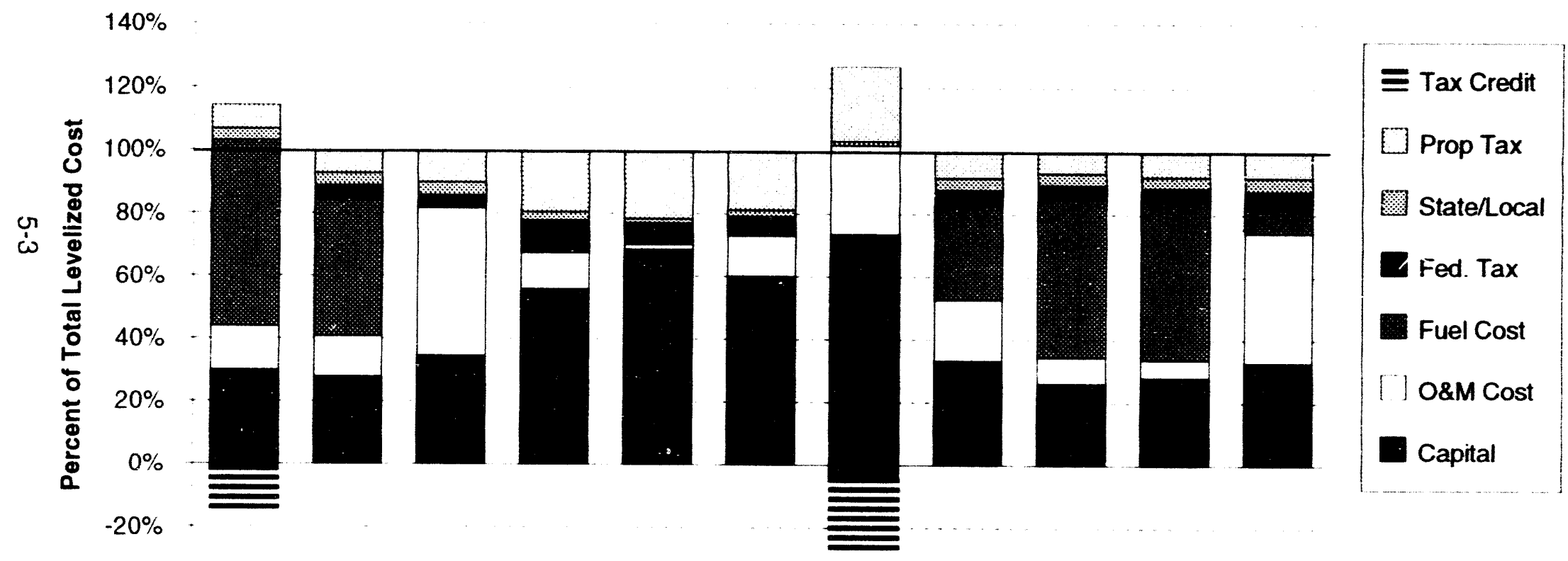

$-40 \%$

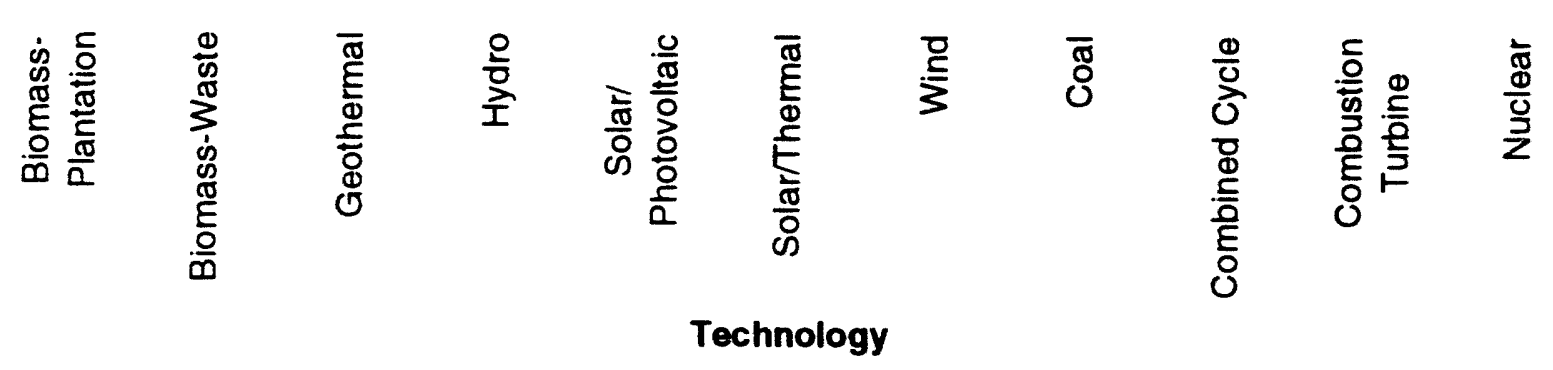

Note: Costs for each technology sum to $100 \%$. 


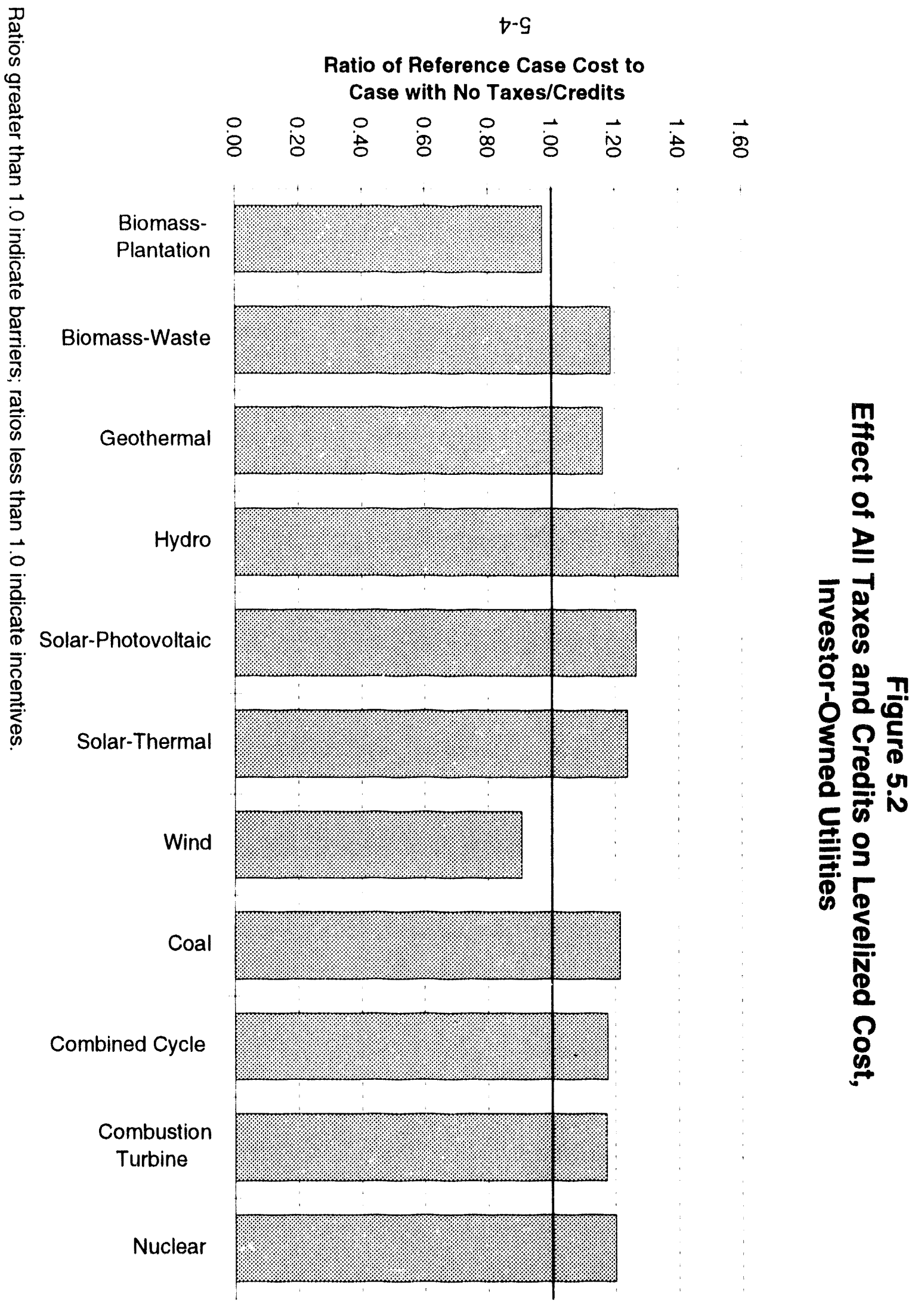


Changes in costs due to the $6 \%$ state income tax are small, but favorable, for several of the renewable technologies. This is due largely to accelerated depreciation of investment in plant and equipment, which mirrored the tax lives used for federal purposes. These effects are described in more detail in Sect. 5.2.1.

The effects of federal income taxes (including accelerated depreciation) and production tax credits quantified in Table 5.1 are characterized in Fig. 5.3. Technologies which have no tax credits associated with them and which have fairly long tax depreciation lives (i.e., the conventionals, hydro, and waste wood biomass plants) are harmed by federal taxes by approximately $2-4 \%$. Renewables that have short tax depreciation lives and are able to take advantage of production tax credits benefit from federal taxes. These issues are discussed in detail in Sect. 5.2.1.

We also examined the effects of three ratemaking procedures-the amount of CWIP allowed in the rate base, normalization vs flow-through of taxes and credits, and the ability of IOUs to pass fuel price increases automatically to ratepayers-on decisionmaking criteria that IOUs use. We show the results of these scenarios in Table 5.2 .

As can be seen by the results in Table 5.2, allowing all of CWIP in the rate base has negligible effects on the criteria considered. The rate base calculation adjusts required revenues to provide an allowed return to the utility each year. Because the model discounts the costs and returns over the life of the facility by the allowed returns, there is essentially no net change in the criteria. This is discussed in Sect. 5.3.1.

In the reference scenario, taxes and credits are normalized. This means that the reduction in taxes due to accelerated depreciation are not passed directly to the ratepayers in the year of their occurrence, but are spread over the life of the facility. Customers pay the deferred credits early, at which point a reserve for payment of deferred taxes is established as a liability on the balance sheet. Later in the plant's life, this reserve is depleted as the deferred taxes are paid.

When taxes flow through to customers, the levelized cost increases. The capitalintensive renewables experience increases in cost of over $10 \%$, while the conventionals experience cost increases of around $2 \%$. There are several reasons for these results. They are discussed in more detail in Sect. 5.3.2.

The results of the automatic fuel adji stment clause as modeled indicate little effect on the decisionmaking criteria. Gas-fueled technologies are the most sensitive because gas prices are assumed to increase faster than the prices of other fuels. The levelized cost for a combustion turbine declines $0.1 \%$ without the clause because of delays in passing the higher fuel prices to customers. For example, the IRR declined $0.6 \%$ because of the delay in receiving the funds. The major issue with fuel adjustment clauses is not the economic impact on the utility and its customers but the lessening of financial risk to the utility from fuel cost increases. This lowers the riskiness of fuel-intensive technologies more than the capital-intensive technologies. 
Figure 5.3

Effect of Federal Taxes and Credits on Levelized Cost, Investor-Owned Utilities

1.20

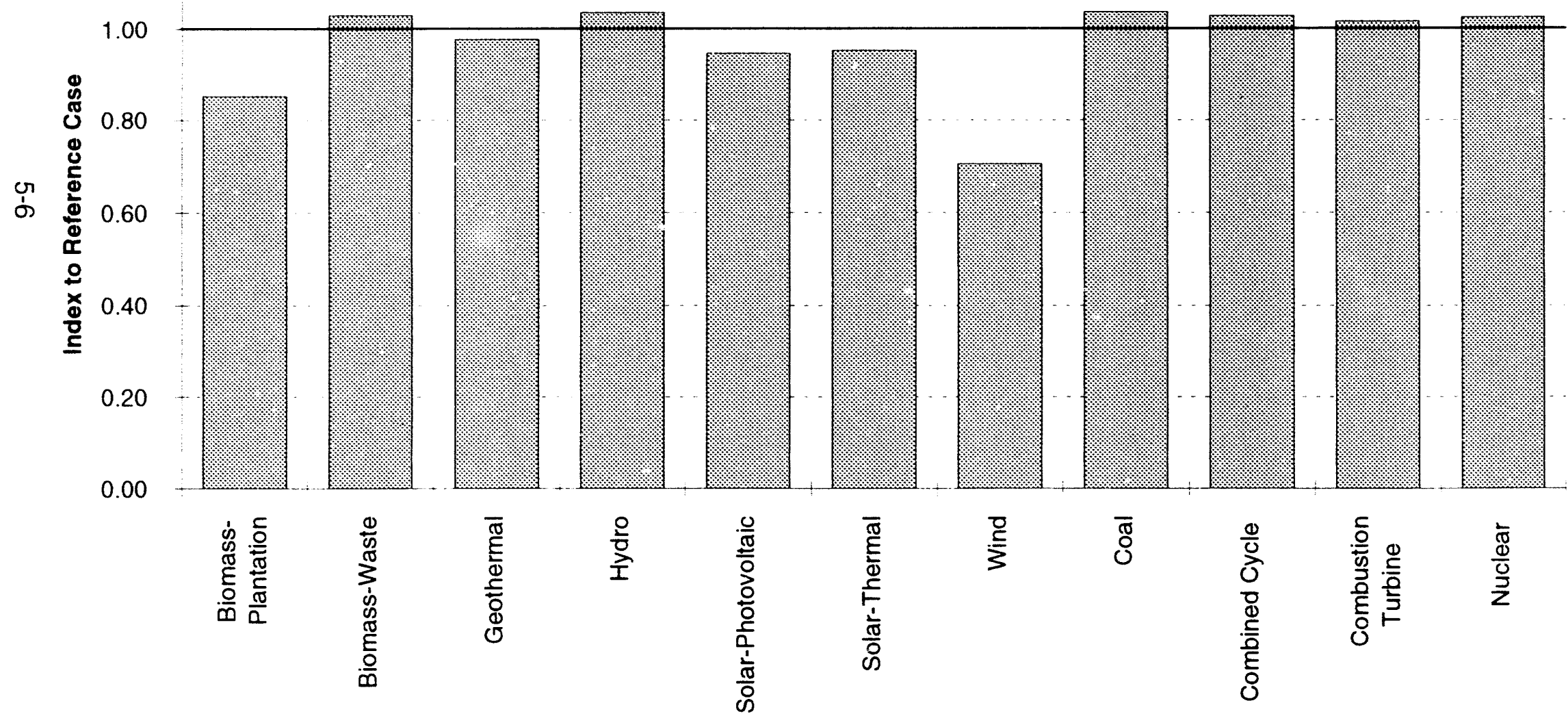

Ratios greater than 1.0 indicate barriers; ratios less than 1.0 indicate incentives. 
Table 5.2

Summary of Ratemaking Effects on Levelized Cost and Internal Rate of Return, Investor-Owned Utilities

(Ratio of Case with Ratemaking Procedure to Case Without)

\begin{tabular}{|c|c|c|c|}
\hline Generating Type & $\begin{array}{l}\text { Effect of Not } \\
\text { Including CWIP } \\
\text { in Rate Base }\end{array}$ & $\begin{array}{c}\text { Effect of } \\
\text { Normalizing } \\
\text { Taxes in Rate Base }\end{array}$ & $\begin{array}{l}\text { Effect of Automatic } \\
\text { Fuel Adjustments }\end{array}$ \\
\hline \multicolumn{4}{|l|}{ RENEWABLES } \\
\hline \multicolumn{4}{|l|}{ Biomass-Plantation } \\
\hline Levelized Cost & 1.00 & 0.98 & 1.00 \\
\hline Int. Rate of Return & 1.00 & 0.99 & 1.00 \\
\hline \multicolumn{4}{|l|}{ Biomass-Waste } \\
\hline Levelized Cost & 1.00 & 0.98 & 1.00 \\
\hline Int. Rate of Return & 1.00 & 0.99 & 1.00 \\
\hline \multicolumn{4}{|l|}{ Geothermal } \\
\hline Levelized Cost & 1.00 & 0.94 & 1.00 \\
\hline Int. Rate of Return & 1.00 & 0.95 & 1.00 \\
\hline \multicolumn{4}{|l|}{ Hydro } \\
\hline Levelized Cost & 1.00 & 0.90 & 1.00 \\
\hline Int. Rate of Return & 1.00 & 0.98 & 1.00 \\
\hline \multicolumn{4}{|l|}{ Solar-Photovoltaic } \\
\hline Levelized Cost & 1.00 & 0.89 & 1.00 \\
\hline Int. Rate of Return & 1.00 & 0.94 & 1.00 \\
\hline \multicolumn{4}{|l|}{ Solar-Thermal } \\
\hline Levelized Cost & 1.00 & 0.90 & 1.00 \\
\hline Int. Rate of Return & 1.00 & 0.94 & 1.00 \\
\hline \multicolumn{4}{|l|}{ Wind } \\
\hline Levelized Cost & 1.00 & 0.89 & 1.00 \\
\hline Int. Rate of Return & 1.00 & 0.95 & 1.00 \\
\hline \multicolumn{4}{|l|}{ CONVENTIONAL } \\
\hline \multicolumn{4}{|l|}{ Coal } \\
\hline Levelized Cost & 1.00 & 0.98 & 1.00 \\
\hline Int. Rate of Return & 1.00 & 0.99 & 1.00 \\
\hline \multicolumn{4}{|l|}{ Combined Cycle } \\
\hline Levelized Cost & 1.00 & 0.98 & 1.00 \\
\hline Int. Rate of Return & 1.00 & 0.99 & 1.01 \\
\hline \multicolumn{4}{|l|}{ Combustion Turbine } \\
\hline Levelized Cost & 1.00 & 0.98 & 1.00 \\
\hline Int. Rate of Return & 1.00 & 0.98 & 1.01 \\
\hline \multicolumn{4}{|l|}{ Nuclear } \\
\hline Levelized Cost & 1.00 & 0.97 & 1.00 \\
\hline Int. Rate of Return & 1.00 & 0.98 & 1.00 \\
\hline
\end{tabular}

Note: The ratemaking effects are the ratio of the levelized costs and IRR of the scenarios with the ratemaking by the cost and IRR without the procedure. Levelized cost ratios greater than 1.0 indicate barriers; ratios less than 1.0 indicate incentives. IRR ratios greater than 1.0 indicate incentives; ratios less than 1.0 indicate barriers. 


\subsection{KEY TAX EFFECTS}

Only some of the tax measures have a major impact on the costs of the technologies. Of those studied, aspects of federal income tax policy were the most significant. Tax depreciation lives and the availability of tax credits were the most important factors. Apart from federal taxes, local property taxes also affect capitalintensive technologies more than those that are not as capital-intensive.

\subsubsection{Federal Income Tax Effects}

The effect of federal income taxes and credits were surprising. As shown in Fig. 5.3 , the conventionals and two of the renewables had slight increases (2-4\%) in their cost because of taxes. But the remaining renewables showed significant declines. There are two main reasons for the difference. Four of the renewables used a double-declining balance, 5-year-tax-depreciation life. In addition, two renewables used the production tax credit. In Table 5.3 we show the results of varying these parameters separately and together.

First, we studied accelerated depreciation by itself by setting the tax depreciation equal to book depreciation. (The reference tax and book lives are listed in Table 4.3.) The geothermal, solar, and wind technologies had tax lives of 5 years and consequently used a double-declining-balance depreciation schedule. The rest of the technologies had tax lives of 15 or 20 years. As can be seen in Table 5.3 and Fig. 5.4, accelerated depreciation had the most effect on those technologies with short tax lives. (Hydro is similarly affected because of the large change in its tax life, from 20 to 50 years.)

Accelerated depreciation lowers levelized costs because it lowers taxes to the utility in the early years. For tax purposes, the project has much higher depreciation expenses in the early years, which lowers the utility's tax payments. After the tax depreciation life is past, tax payments are higher because there is no depreciation to lower taxable income. The total taxes paid are generally the same over the life of the plant, but because of the time value of money, the accelerated depreciation is still a net benefit. Lower taxes early in the plant life more than offset the higher taxes later. There is an added factor due to normalizing tax payments that accentuates the benefit from accelerated depreciation. This is discussed in Sect. 5.3.2.

There is a production tax credit available to the wind and biornass plantation technologies. It is described in Sect. 4.2.7. In Fig. 5.4 and Table 5.3, we show that the credits are a significant benefit to the cost of the technologies. The production tax credit lowers the cost of wind power $27 \%$ and the biomass plantation by $17 \%$. Both of the technologies have "prices" low enough in every year to take full advantage of the 1.56 credit. (The model divides the calculated required revenue by the production amount to determine a quasi-price for the plant.) The wind plant is most affected on a percentage basis because of its lower base cost. For both technologies, the reduction in levelized cost is $1.24 € / \mathrm{KWh}$. Actually, the credit alone is worth only $0.75 \% / \mathrm{kWh}$ in levelized cost reduction, because of the 10 year life of the credit, but the synergistic effect on prices and 
Table 5.3

Summary of Federal Income Tax Effects on

Levelized Cost and Internal Rate of Return, Investor-Owned Utilities

(Ratio of Case with Tax Policies to Case Without)

\begin{tabular}{|c|c|c|c|c|}
\hline Generating Type & $\begin{array}{c}\text { Effect of } \\
\text { Including } \\
\text { Income Taxes } \\
\text { and Credits }\end{array}$ & $\begin{array}{c}\text { Effect of } \\
\text { Including } \\
\text { Accelerated } \\
\text { Depreciation }\end{array}$ & $\begin{array}{l}\text { Effect of } \\
\text { Including } \\
\text { Federal } \\
\text { Tax Credits }\end{array}$ & $\begin{array}{l}\text { Effect of Includ- } \\
\text { ing Accel. } \\
\text { Depreciation and } \\
\text { Tax Credits }\end{array}$ \\
\hline \multicolumn{5}{|l|}{ RENEWABLES } \\
\hline \multicolumn{5}{|l|}{ Biomass-Plantation } \\
\hline Levelized Cost & 0.85 & 0.97 & 0.83 & 0.81 \\
\hline Int. Rate of Return & 0.99 & 0.99 & 1.00 & 0.99 \\
\hline \multicolumn{5}{|l|}{ Biomass-Waste } \\
\hline Levelized Cost & 1.03 & 0.97 & 1.00 & 0.97 \\
\hline Int. Rate of Return & 0.99 & 0.99 & 1.00 & 0.99 \\
\hline \multicolumn{5}{|l|}{ Geothermal } \\
\hline Levelized Cost & 0.98 & 0.90 & 1.00 & 0.90 \\
\hline Int. Rate of Return & 0.96 & 0.95 & 1.00 & 0.95 \\
\hline \multicolumn{5}{|l|}{ Hydro } \\
\hline Levelized Cost & 1.04 & 0.90 & 1.00 & 0.90 \\
\hline Int. Rate of Return & 0.98 & 0.98 & 1.00 & 0.98 \\
\hline \multicolumn{5}{|l|}{ Solar-Photovoltaic } \\
\hline Levelized Cost & 0.95 & 0.81 & 1.00 & 0.81 \\
\hline Int. Rate of Return & 0.95 & 0.94 & 1.00 & 0.94 \\
\hline \multicolumn{5}{|l|}{ Solar-Thermal } \\
\hline Levelized Cost & 0.95 & 0.83 & 1.00 & 0.83 \\
\hline Int. Rate of Return & 0.95 & 0.94 & 1.00 & 0.94 \\
\hline \multicolumn{5}{|l|}{ Wind } \\
\hline Levelized Cost & 0.71 & 0.81 & 0.73 & 0.62 \\
\hline Int. Rate of Return & 0.95 & 0.95 & 1.00 & 0.95 \\
\hline \multicolumn{5}{|l|}{ CONVENTIONAL } \\
\hline \multicolumn{5}{|l|}{ Coal } \\
\hline Levelized Cost & 1.04 & 0.97 & 1.00 & 0.97 \\
\hline Int. Rate of Return & 0.99 & 0.99 & 1.00 & 0.99 \\
\hline \multicolumn{5}{|l|}{ Combined Cycle } \\
\hline Levelized Cost & 1.03 & 0.98 & 1.00 & 0.98 \\
\hline Int. Rate of Return & 0.99 & 0.99 & 1.00 & 0.99 \\
\hline \multicolumn{5}{|l|}{ Combustion Turbine } \\
\hline Levelized Cost & 1.02 & 0.96 & 1.00 & 0.96 \\
\hline Int. Rate of Return & 0.98 & 0.98 & 1.00 & 0.98 \\
\hline \multicolumn{5}{|l|}{ Nuclear } \\
\hline Levelized Cost & 1.03 & 0.96 & 1.00 & 0.96 \\
\hline Int. Rate of Return & 0.98 & 0.98 & 1.00 & 0.98 \\
\hline
\end{tabular}

Note: The tax effects are the ratios of the levelized costs and IRRs of the cases with the tax policies in effect to the cases without the tax policies. Levelized cost ratios greater than 1.0 indicate barriers; ratios less than 1.0 indicate incentives. IRR ratios greater than 1.0 indicate incentives; ratios less than 1.0 indicate barriers. 
Figure 5.4

Effect of Accelerated Depreciation and Tax Credits on Levelized Cost, Investor-Owned Utilities

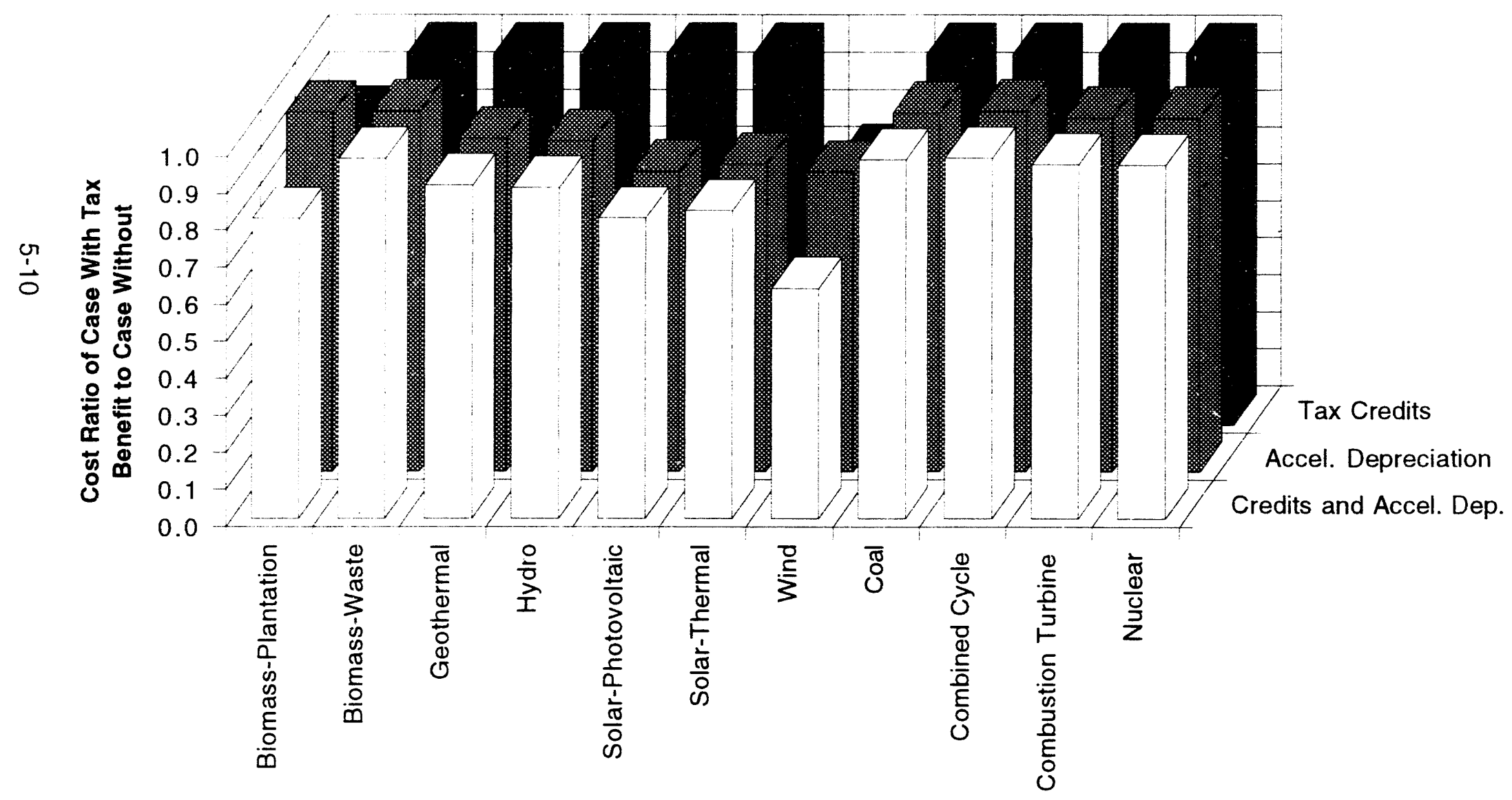

Ratios greater than 1.0 indicate barriers; ratios less than 1.0 indicate incentives. 
income taxes lowers the levelized cost a further $64 \%$, to $1.24 \% / \mathrm{kWh}$. This effect is explained in Appendix $A$.

Section 1916 of the Energy Policy Act permanently extends the energy investment credit for solar and geothermal property. However, the tax code was changed in 1992 prior to EPACT such that public utilities are not eligible for this credit. Since NUG's can take the credit, this creates a tax advantage for NUG development of these technologies rather than IOU's.

The final column in Table 5.3 lists the effect of accelerated depreciation and the tax credits together. We ran a set of cases using book depreciation and no credits, and found that the levelized costs rose for all cases, compared to the reference cases. By dividing the reference cost by this higher cost we find that the combined effect is roughly equal to multiplying the effect of each together.

\subsubsection{Property Tax Effects}

The effects of property taxes are shown in Table 5.1 above. Property taxes affect the capital-intensive renewable technologies (hydro, solar, wind) much more than the conventional technologies, with costs raised from $20 \%$ to $30 \%$. Because much of the costs for the renewables are capital-related, as opposed to fuel- or operating-related, a higher proportion of their cost is subject to the tax. In addition, the property tax declines over time as the plant is depreciated. This means the cost from property tax is "frontloaded", with higher payments early in the life of the plant, which in turn have a higher weighting when levelizing the cost due to the discount rate.

To understand the effect of different methods for calculating the property tax base we used two other methods, gross book value and the net present value of the future cash flow stream. Also, we studied the effect of charging property tax on the added plant and equipment but not on the original land value. The results are shown in Table 5.4 and Fig. 5.5. When compared to the no-property-tax scenario, all have roughly the same result: a much higher impact on the capital-intensive renewables than on the conventionals. Since the cost of land was set at only $5 \%$ of total capital cost (except in the case of wind technology, where it is set at 10\%), the effect of exempting land from the property tax is not large. The conventionals and biomass technologies had their overall costs lowered less than $1 \%$ by exempting land, while solar and hydro technologies dropped around $1.5 \%$, and wind $2.7 \%$.

\subsubsection{Input Tax Effects}

We show the effect of taxes on the inputs to production (labor, energy, material, and land) in Table 5.5. Most technologies show an overall effect from input taxes of around $7 \%$ of the levelized cost. Input taxes have a slightly larger effect on wind plants because the production tax credits lower the underlying cost of both scenarios. The input taxes are thus a higher percentage of the remaining cost. If the production tax credit is eliminated from both the reference and the no-input-tax scenarios, the effect of input taxes on wind becomes only $7 \%$, similar to the other technologies. 
Table 5.4

Summary of Property Tax Effects on Levelized Cost and Internal Rate of Return, Investor-Owned Utilities

(Ratio of Alternative Scenarios to No Property Tax Scenario)

\begin{tabular}{|c|c|c|c|c|}
\hline Generating Type & $\begin{array}{c}\text { Effect of } \\
\text { Tax Based on } \\
\text { Net Book Value } \\
\text { (Reference) }\end{array}$ & $\begin{array}{c}\text { Effect of } \\
\text { Tax Based on } \\
\text { Gross Book Value }\end{array}$ & $\begin{array}{c}\text { Effect of } \\
\text { Tax Based on } \\
\text { Future Cash Flow }\end{array}$ & $\begin{array}{c}\text { Effect of } \\
\text { Tax Based un } \\
\text { Net Book Value + } \\
\text { No Tax on Land }\end{array}$ \\
\hline \multicolumn{5}{|l|}{ RENEWABLES } \\
\hline \multicolumn{5}{|l|}{ Biomass-Plantation } \\
\hline Levelized Cost & 1.09 & 1.14 & 1.09 & 1.08 \\
\hline Int. Rate of Return & 1.00 & 1.00 & 1.00 & 1.00 \\
\hline \multicolumn{5}{|l|}{ Biomass-Waste } \\
\hline Levelized Cost & 1.08 & 1.13 & 1.08 & 1.07 \\
\hline Int. Rate of Return & 1.00 & 1.00 & 1.00 & 1.00 \\
\hline \multicolumn{5}{|l|}{ Geothermal } \\
\hline Levelized Cost & 1.11 & 1.18 & 1.09 & 1.10 \\
\hline Int. Rate of Return & 1.00 & 1.00 & 1.00 & 1.00 \\
\hline \multicolumn{5}{|l|}{ Hydro } \\
\hline Levelized Cost & 1.24 & 1.35 & 1.24 & 1.22 \\
\hline Int. Rate of Return & 1.00 & 1.00 & 1.00 & 1.00 \\
\hline \multicolumn{5}{|l|}{ Solar-Photovoltaic } \\
\hline Levelized Cost & 1.27 & 1.44 & 1.20 & 1.25 \\
\hline Int. Rate of Return & 1.00 & 1.00 & 1.00 & 1.00 \\
\hline \multicolumn{5}{|l|}{ Solar-Thermal } \\
\hline Levelized Cost & 1.23 & 1.37 & 1.17 & 1.21 \\
\hline Int. Rate of Return & 1.00 & 1.00 & 1.00 & 1.00 \\
\hline \multicolumn{5}{|l|}{ Wind } \\
\hline Levelized Cost & 1.31 & 1.48 & 1.24 & 1.26 \\
\hline Int. Rate of Return & 1.00 & 1.00 & 1.00 & 1.00 \\
\hline \multicolumn{5}{|l|}{ CONVENTIONAL } \\
\hline \multicolumn{5}{|l|}{ Coal } \\
\hline Levelized Cost & 1.09 & 1.15 & 1.10 & 1.08 \\
\hline Int. Rate of Return & 1.00 & 1.00 & 1.00 & 1.00 \\
\hline \multicolumn{5}{|l|}{ Combined Cycle } \\
\hline Levelized Cost & 1.07 & 1.12 & 1.07 & 1.07 \\
\hline Int. Rate of Return & 1.00 & 1.00 & 1.00 & 1.00 \\
\hline \multicolumn{5}{|l|}{ Combustion Turbine } \\
\hline Levelized Cost & 1.09 & 1.14 & 1.08 & 1.08 \\
\hline Int. Rate of Return & 1.00 & 1.00 & 1.00 & 1.00 \\
\hline \multicolumn{5}{|l|}{ Nuclear } \\
\hline Levelized Cost & 1.09 & 1.14 & 1.09 & 1.08 \\
\hline Int. Rate of Return & 1.00 & 1.00 & 1.00 & 1.00 \\
\hline
\end{tabular}

Note: Effects are the ratios of the levelized costs and IRRs of the cases with the listed property tax method to the case with no property taxes. Levelized cost ratios greater than 1.0 indicate barriers; ratios less than 1.0 indicate incentives. IRR ratios greater than 1.0 indicate incentives; ratios less than 1.0 indicate barriers. 


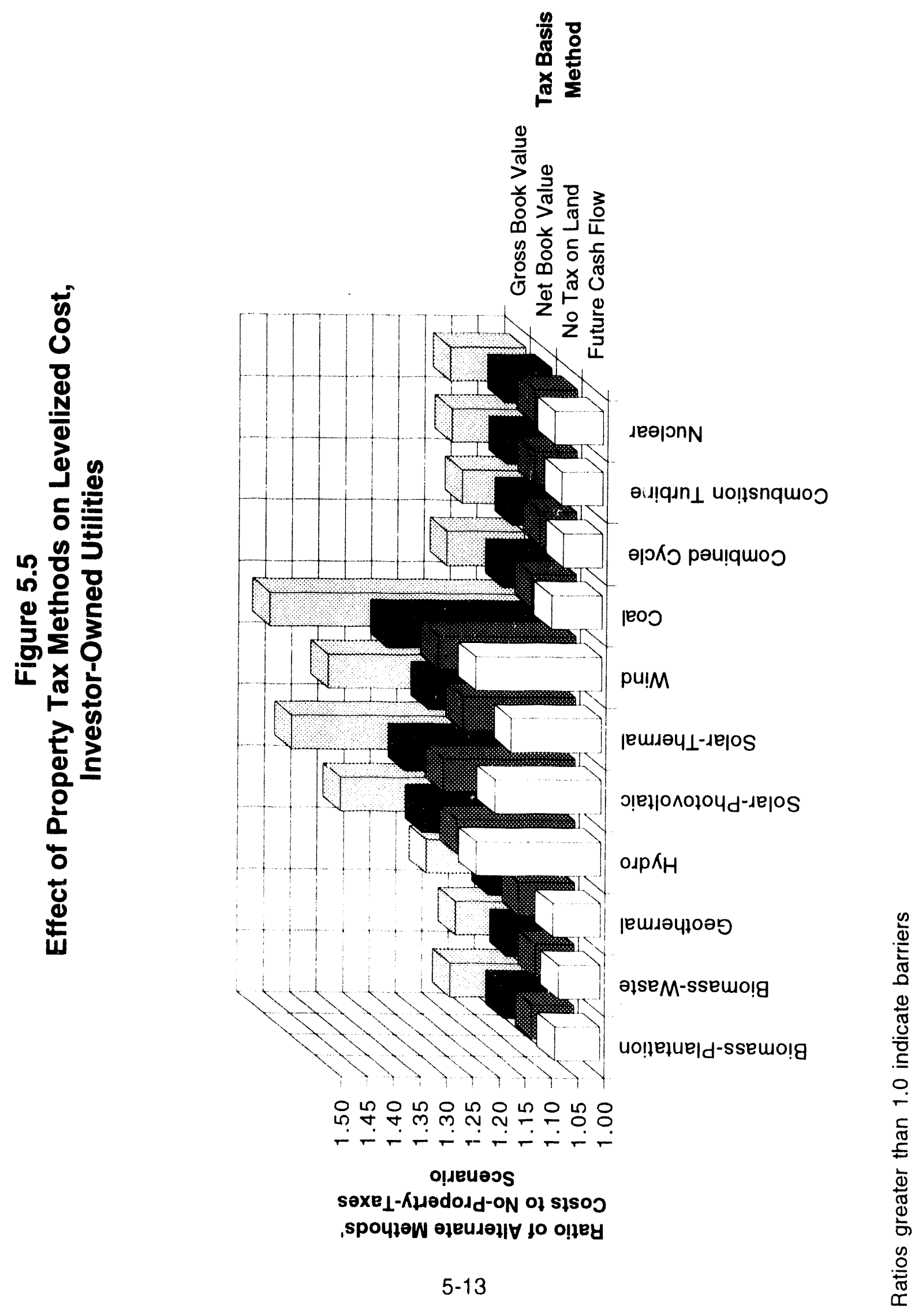


Table 5.5

Summary of State Input Tax Effects on Levelized Cost and Internal Rate of Return,

Investor-Owned Utilities

(Ratio of Case with Taxes to Case Without)

\begin{tabular}{|c|c|c|c|c|c|}
\hline Generating Type & $\begin{array}{c}\text { Effect of } \\
\text { All Input Taxes }\end{array}$ & $\begin{array}{c}\text { Effect of } \\
\text { Labor Taxes }\end{array}$ & $\begin{array}{c}\text { Effect of } \\
\text { Fuel Taxes }\end{array}$ & $\begin{array}{c}\text { Effect of } \\
\text { Material Taxes }\end{array}$ & $\begin{array}{c}\text { Effect of } \\
\text { Land Taxes }\end{array}$ \\
\hline \multicolumn{6}{|l|}{ RENEWABLES } \\
\hline \multicolumn{6}{|l|}{ Biomass-Plantation } \\
\hline Levelized Cost & 1.07 & 1.02 & 1.03 & 1.01 & 1.00 \\
\hline Int. Rate of Return & 1.00 & 1.00 & 1.00 & 1.00 & 1.00 \\
\hline \multicolumn{6}{|l|}{ Biomass-Waste } \\
\hline Levelized Cost & 1.06 & 1.02 & 1.02 & 1.01 & 1.00 \\
\hline Int. Rate of Return & 1.00 & 1.00 & 1.00 & 1.00 & 1.00 \\
\hline \multicolumn{6}{|l|}{ Geothermal } \\
\hline Levelized Cost & 1.07 & 1.04 & 1.00 & 1.02 & 1.00 \\
\hline Int. Rate of Return & 1.00 & 1.00 & 1.00 & 1.00 & 1.00 \\
\hline \multicolumn{6}{|l|}{ Hydro } \\
\hline Levelized Cost & 1.07 & 1.04 & 1.00 & 1.02 & 1.00 \\
\hline Int. Rate of Return & 1.00 & 1.00 & 1.00 & 1.00 & 1.00 \\
\hline \multicolumn{6}{|l|}{ Solar-Photovoltaic } \\
\hline Levelized Cost & 1.07 & 1.04 & 1.00 & 1.02 & 1.00 \\
\hline Int. Rate of Return & 1.00 & 1.00 & 1.00 & 1.00 & 1.00 \\
\hline \multicolumn{6}{|l|}{ Solar-Thermal } \\
\hline Levelized Cost & 1.07 & 1.04 & 1.00 & 1.02 & 1.00 \\
\hline Int. Rate of Return & 1.00 & 1.00 & 1.00 & 1.00 & 1.00 \\
\hline \multicolumn{6}{|l|}{ Wind } \\
\hline Levelized Cost & 1.10 & 1.06 & 1.00 & 1.03 & 1.01 \\
\hline Int. Rate of Return & 1.00 & 1.00 & 1.00 & 1.00 & 1.00 \\
\hline \multicolumn{6}{|l|}{ CONVENTIONAL } \\
\hline \multicolumn{6}{|l|}{ Coal } \\
\hline Levelized Cost & 1.07 & 1.03 & 1.02 & 1.02 & 1.00 \\
\hline Int. Rate of Return & 1.00 & 1.00 & 1.00 & 1.00 & 1.00 \\
\hline \multicolumn{6}{|l|}{ Combined Cycle } \\
\hline Levelized Cost & 1.06 & 1.02 & 1.03 & 1.01 & 1.00 \\
\hline Int. Rate of Return & 1.00 & 1.00 & 1.00 & 1.00 & 1.00 \\
\hline \multicolumn{6}{|l|}{ Combustion Turbine } \\
\hline Levelized Cost & 1.06 & 1.02 & 1.03 & 1.01 & 1.00 \\
\hline Int. Rate of Return & 1.00 & 1.00 & 1.00 & 1.00 & 1.00 \\
\hline \multicolumn{6}{|l|}{ Nuclear } \\
\hline Levelized Cost & 1.07 & 1.04 & 1.01 & 1.02 & 1.00 \\
\hline Int. Rate of Return & 1.00 & 1.00 & 1.00 & 1.00 & 1.00 \\
\hline
\end{tabular}

Note: The tax effects are the ratios of the levelized costs and IRRs of the cases with taxes to the cases without the taxes. Levelized cost ratios greater than 1.0 indicate barriers; ratios less than 1.0 indicate incentives. IRR ratios greater than 1.0 indicate incentives; ratios less than 1.0 indicate barriers. 
We also show in Table 5.5 the results of each input tax separately. The change due to taxes on each component of the inputs is roughly proportional to the percentage each component has on the overall cost. For the capital-intensive technologies, little fuel is involved beyond that used during construction; the change is driven by the taxes on material, labor, and land. The most fuel-intensive technologies-biomass, combined cycle, and combustion turbines-are more affected by the fuel tax. With these, the fuel tax represents about half of the total impact from the taxes on inputs.

\subsection{KEY RATEMAKING EFFECTS}

\subsubsection{CWIP in Rate Base}

Allowing CWIP in the rate base raised the levelized cost for most technologies, but the effects were small, even for nuclear plants with 7-year construction periods. Hydro experienced the largest increase in cost $(0.4 \%$ increase); nuclear experienced a $0.3 \%$ increase.

The two key decisionmaking criteria (levelized cost, IRR) are not the best indicators of CWIP's effects. They capture the costs of a project over its life but are not sensitive to the timing of the costs. The rate base formula levelizes the effects of changing the time frame when revenues are received. Revenues received early have a higher weighting in the levelized cost but lower the net investment. The decrease in net investment, in turn, lowers revenues required later during operation of the plant.

The main benefit from allowing CWIP is the reduction in net funds required from the utility during construction. For the nuclear plant, required debt and equity amounts decline 12\% (see Fig. 5.6). However, the short construction schedule of the renewable technologies mean that the utility does not see as much of a benefit from CWIP. The capital requirement for the wind plant (with a 2-year construction) is reduced only $1.3 \%$. Even the biomass plant, with a 4 -year schedule, has only a $5 \%$ reduction in the maximum capital investment. In real-world applications, a utility may see its bond ratings improve and consequent interest rate on debt decline because of the lower capital exposure, but we did not analyze the effect in this study.

\subsubsection{Tax Flow-Through Effects}

As shown above in Table 5.2, allowing customers to benefit from the favorable provisions of federal tax laws immediately has an unfavorable effect on levelized cost. There are two factors to be considered. First, tax laws require that if flow-through accounting for tax benefits is used rather than normalization, the tax depreciation lives of the assets must be increased by a statutory amount. Assets with deprecation lives of 5 years must be increased to 12; those with 15 years to 20; and those with 20 to 28 years. Hydro must extend its tax life to 50 years. Of course, technologies with the largest increase in tax lives are most affected by this provision of the tax laws. For example, changing the tax life for solar-photovoltaic from 5 to 12 years increases its levelized cost by $6 \%$. Hydro is more adversely affected by the change; its cost increases by $10 \%$ if its tax depreciation life is changed from 20 to 50 years. Dedicated-plantation biomass, which 


\section{Figure 5.6 \\ Effect of CWIP Allowance on \\ Cumulative Debt and Equity Cash Flow, \\ IOU Nuclear Plant}

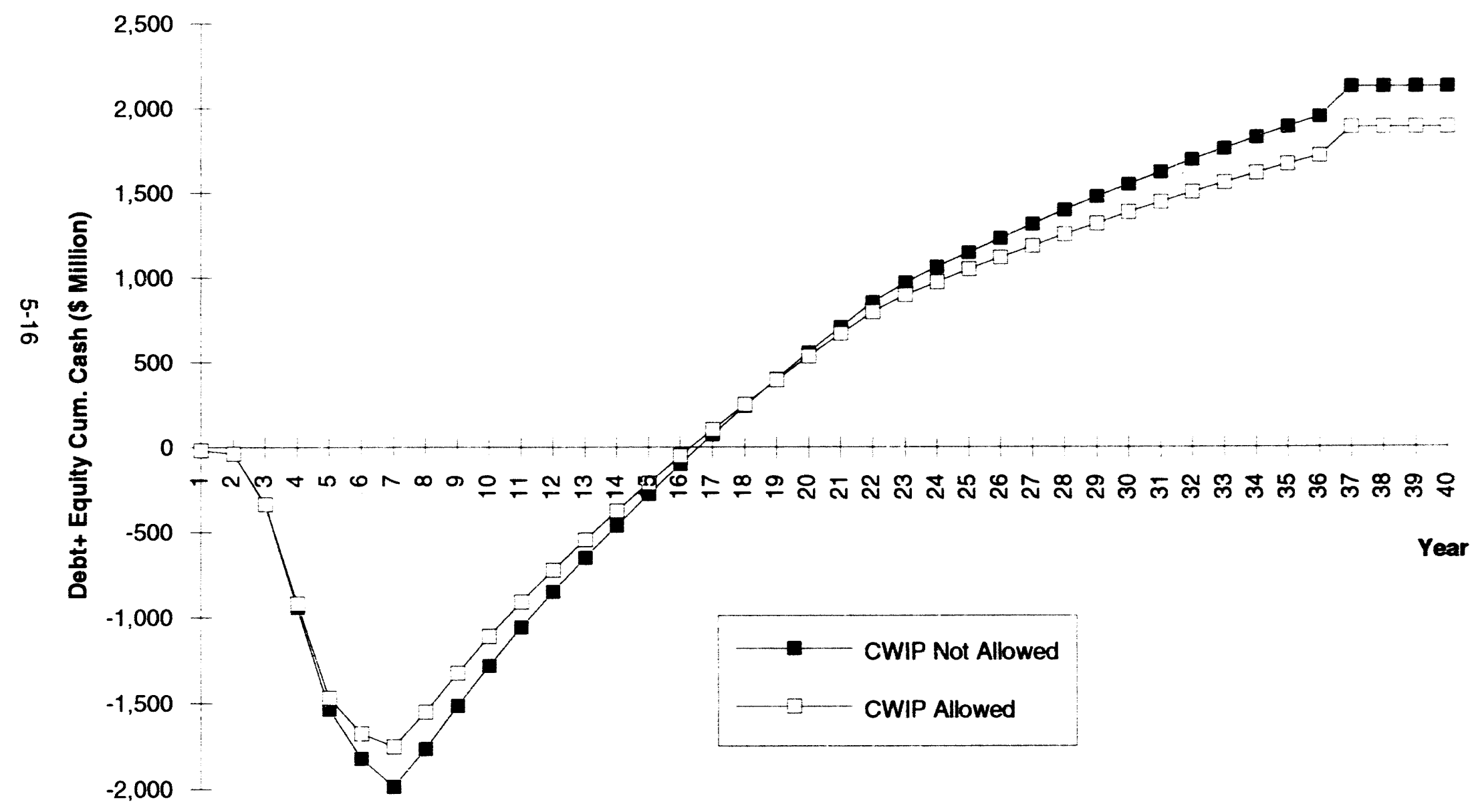


experiences a tax life increase from 20 to 28 years under flow-through accounting, experiences a cost increase of only $2.0 \%$.

The other factor explaining the effects of normalization is that taxes are collected from customers that are deferred, or paid to the government some years later. These tax deferrals can be from accelerated depreciation or allowance for borrowed funds during construction. Customers pay higher prices early in the plant life, but pay less later. These advance payments are used to lower the amount of equity in the plant by creating a deferred tax liability. Because customers do not have to pay any return on this amount, their prices are lowered.

Fig. 5.7 depicts the revenues paid by the customers for a geothermal plant under three scenarios: (1) normalized taxes, (2) flow-through with a 5-year tax depreciation life, and (3) flow-through with the required 12-year tax life. Before the plant begins operation, customers pay nothing under normalization and actually get a small rebate under flowthrough because of the tax reduction for interest expense. As the plant begins operation, the normalized revenue requirements are high because deferred taxes raise the cost to customers. The flow-through cases have low revenue requirements in the first few years because the accelerated depreciation greatly reduces the tax cost. However, their revenue requirements are soon higher than the normalized case because under normalization, the deferred tax liability builds up and lowers the rate base. The tax flow-through cases have a sudden jump as the plant finishes its tax life. Discounting these revenue streams shows that the flow-through cost with 12 year depreciation is $6 \%$ higher than the normalized cost. Even using the 5 year depreciation life, the levelized cost of flow-through is $4 \%$ higher than the normalized case.

\subsection{SENSTTIVITY TO INPUT ASSUMPTIONS}

All of the results shown in Tables 5.1 through 5.5 are based on the values that we used to quantify the parameters of the technologies. Those values are contained in Tables 3.1 through 3.3 of Sect. 3. The data quantifying the parameters of each of the 11 technologies in those tables are "conventional wisdom" today. That is, the financial costs, engineering characteristics, and assigned work loads (i.e., capacity factors) of the technologies are reasonable estimates of what a "representative" electric utility would confront today.

Clearly, changing these input assumptions would affect the base values of the levelized cost and IRR, the decisionmaking criteria used in this study. To show this, we conducted a sensitivity study of the assigned values for key parameters. The results of some of these sensitivities are shown in Tables 5.6 and 5.7. The ratio of levelized costs between cases with and without specific tax and ratemaking procedures are shown both for a technology using the assumed input parameter and with a variation to that parameter. Rather than show the results for all technologies, one renewable and conventional are shown. The summary tax and ratemaking procedures from Tables 1.1 and 1.2 are shown; the values for the cases labeled "reference" are from those tables. 


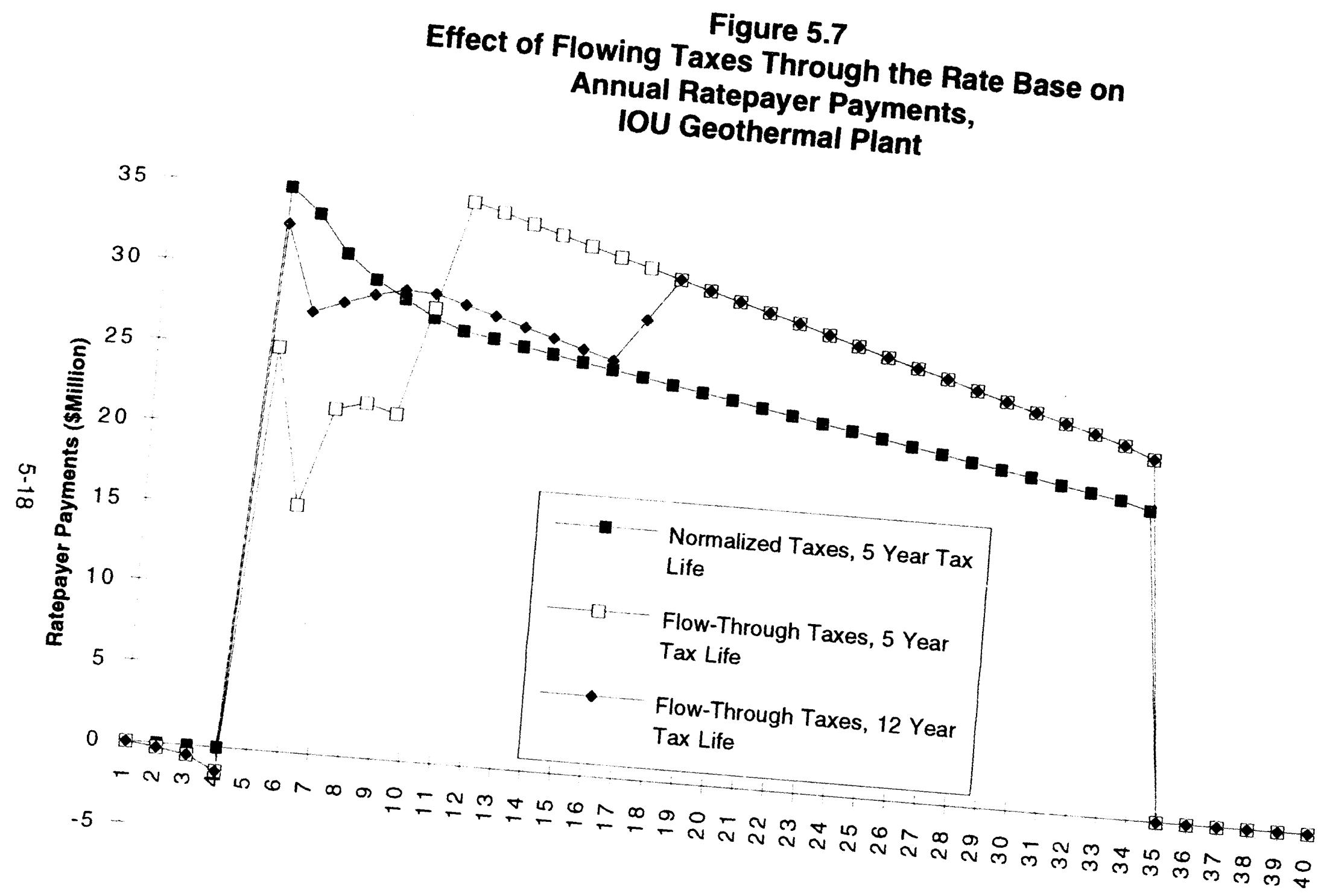


Table 5.6

Summary of Sensitivity Analyses on Input Assumptions,

Tax Effects on Levelized Costs, Investor-Owned Utilities

(Cost Ratio of Case with Taxes to Case without Taxes)

\begin{tabular}{|c|c|c|c|c|c|}
\hline Generating Type & $\begin{array}{l}\text { Effect of } \\
\text { Including } \\
\text { All Taxes } \\
\text { and Credits }\end{array}$ & $\begin{array}{c}\text { Effect of } \\
\text { Including } \\
\text { Property Taxes }\end{array}$ & $\begin{array}{l}\text { Effect of } \\
\text { Including } \\
\text { Input Taxes }\end{array}$ & $\begin{array}{l}\text { Effect of Inclu- } \\
\text { ding State } \\
\text { Income Taxes }\end{array}$ & $\begin{array}{l}\text { Effect of } \\
\text { Including } \\
\text { Federal Taxes } \\
\text { and Credits }\end{array}$ \\
\hline Geothermal - Reference & 1.16 & 1.11 & 1.07 & 1.00 & 0.98 \\
\hline Geothermal - Extended Construction Sched. & 1.17 & 1.11 & 1.07 & 1.00 & 0.98 \\
\hline Nuclear - Reference & 1.20 & 1.09 & 1.07 & 1.00 & 1.03 \\
\hline Nuclear - Extended Construction Schedule & 1.20 & 1.08 & 1.07 & 1.01 & 1.04 \\
\hline \multicolumn{6}{|c|}{ 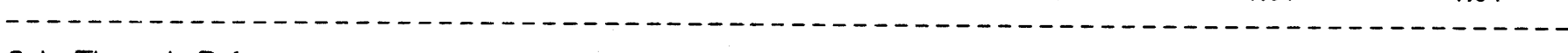 } \\
\hline Solar/Thermal - Reference & 1.24 & 1.23 & 1.07 & 0.99 & 0.95 \\
\hline Solar/Thermal - Low Capital Cost & 1.23 & 1.22 & 1.07 & 0.99 & 0.96 \\
\hline Coal - Reference & 1.22 & 1.09 & 1.07 & 1.01 & 1.04 \\
\hline Coal - Low Capital Cost & 1.20 & 1.08 & 1.06 & 1.01 & 1.03 \\
\hline \multicolumn{6}{|c|}{ 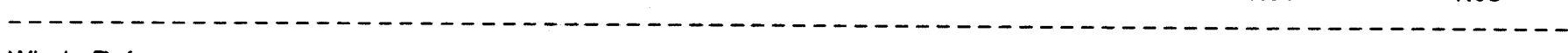 } \\
\hline Wind - Reference & 0.91 & 1.31 & 1.10 & 0.97 & 0.71 \\
\hline Wind - Low Capacity Factor & 1.01 & 1.30 & 1.09 & 0.98 & 0.78 \\
\hline Combustion Turbine - Reference & 1.18 & 1.09 & 1.06 & 1.00 & 1.02 \\
\hline Com. Turbine - Low Capacity Factor & 1.24 & 1.13 & 1.06 & 1.00 & 1.03 \\
\hline \multicolumn{6}{|c|}{ 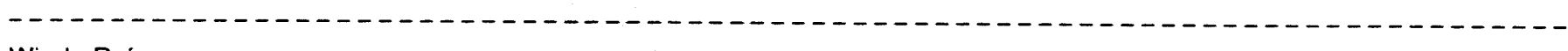 } \\
\hline Wind - Reference & 0.91 & 1.31 & 1.10 & 0.97 & 0.71 \\
\hline Wind - $4 \%$ Inflation & 0.91 & 1.29 & 1.10 & 0.97 & 0.71 \\
\hline Coal - Reference & 1.22 & 1.09 & 1.07 & 1.01 & 1.04 \\
\hline Coal - $4 \%$ Inflation & 1.22 & 1.08 & 1.06 & 1.01 & 1.05 \\
\hline
\end{tabular}

Ratios greater than 1.0 indicate barriers; ratios less than 1.0 indicate incentives. 
Table 5.7

Summary of Sensitivity Analyses on Input Assumptions, Ratemaking Effects on Levelized Costs,

Investor-Owned Utilities

(Cost Ratio of Case with Ratemaking Procedure to Case Without)

\begin{tabular}{|c|c|c|c|}
\hline Generating Type & $\begin{array}{c}\text { Effect of Not } \\
\text { Including CWIP } \\
\text { in Rate Base }\end{array}$ & $\begin{array}{c}\text { Effect of } \\
\text { Normalizing } \\
\text { Taxes in Rate Base }\end{array}$ & $\begin{array}{l}\text { Effect of Automatic } \\
\text { Fuel Adjustments }\end{array}$ \\
\hline Geothermal - Reference & 1.00 & 0.94 & 1.00 \\
\hline Geothermal - Extended Construction Sched. & 1.00 & 0.94 & 1.00 \\
\hline Nuclear - Reference & 1.00 & 0.97 & 1.00 \\
\hline Nuclear - Extended Construction Schedule & 0.99 & 0.97 & 1.00 \\
\hline \multicolumn{4}{|c|}{ 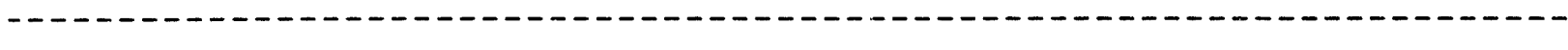 } \\
\hline $\begin{array}{l}\text { Solar/Thermal - Reference } \\
\text { Solar/Thermal - Low Capital Cost }\end{array}$ & $\begin{array}{l}1.00 \\
1.00\end{array}$ & $\begin{array}{l}0.90 \\
0.90\end{array}$ & $\begin{array}{l}1.00 \\
1.00\end{array}$ \\
\hline Coal - Reference & 1.00 & 0.98 & 1.00 \\
\hline Coal - Low Capital Cost & 1.00 & 0.98 & 1.00 \\
\hline \multicolumn{4}{|c|}{ 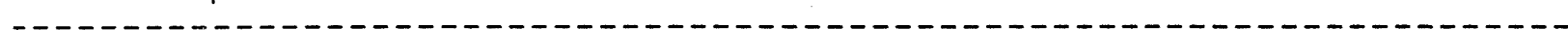 } \\
\hline Wind - Reference & 1.00 & 0.89 & 1.00 \\
\hline Wind - Low Capacity Factor & 1.00 & 0.89 & 1.00 \\
\hline Combustion Turbine - Reference & 1.00 & 0.98 & 1.00 \\
\hline Com. Turbine - Low Capacity Factor & 1.00 & 1.03 & 1.00 \\
\hline \multicolumn{4}{|c|}{ 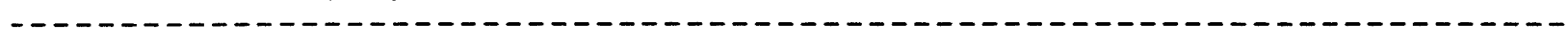 } \\
\hline Wind - Reference & 1.00 & 0.89 & 1.00 \\
\hline Wind $-4 \%$ Inflation & 1.00 & 0.88 & 1.00 \\
\hline Coal - Reference & 1.00 & 0.98 & 1.00 \\
\hline Coal $-4 \%$ Inflation & 1.00 & 1.02 & 1.00 \\
\hline
\end{tabular}

Ratios greater than 1.0 indicate barriers; ratios less than 1.0 indicate incentives. 
As an example, one concern mentioned has been that the construction time may greatly influence the results. We extended the construction time for the geothermal plant from four years to six years and the nuclear technology from seven years to fifteen years. As can be seen in Tables 5.6 and 5.7, the relative impact of taxes and ratemaking on these technologies barely changed.

As another example, reducing the capital cost of the coal option by $20 \%$ from $\$ 1,512 / \mathrm{kW}$ to $\$ 1,210 / \mathrm{kW}$ lowers the levelized cost of the coal option from $\$ 5.90 / \mathrm{kWh}$ to $\$ 5.34 / \mathrm{kWh}$. However, our basic conclusions on ratemaking and taxation barriers to and incentives for adopting the coal technology do not change. The values only change slightly between the reference assumptions and the lower capital cost cases. Similarly, reducing the capital cost of a solar/thermal plant by $20 \%$ does not alter our conclusions about barriers and incentives for solar/thermal.

Another important variable for each of the 11 technologies is the assigned capacity factor. The capacity factors are based on our assumptions about the work load of the technologies and, ultimately, about the relationship between their capital and operating costs. For example, a utility would not construct a nuclear plant for peak-load purposes, and therefore, we assign the nuclear option a $70 \%$ base-load capacity factor. Assuming a $10 \%$ capacity factor for a nuclear plant-as we assumed for the combustion turbine unit-would seriously distort our picture of the financial performance of the plant. A similar argument can be made for running a combustion turbine as a base-load unit. Again, however, changing capacity factors for both technologies in the sensitivity study does not alter our conclusions about barriers and incentives.

Recognizing that simulation results for the $1.5 \mathrm{e} / \mathrm{kWh}$ production tax credit for dedicated-plantation biomass and wind technologies are based directly on the capacity factors assumed in Table 3.1, we also ran sensitivity studies on these values. Again, our overall conclusions on barriers and incentives do not change. For example, reducing the capacity factor of wind from $30 \%$ (Table 3.1 ) to $20 \%$ reduces the production tax credit allowed for wind substantially because the credit is based on kilowatt-hour generation. Except for the case with all taxes removed, our conclusions on ratemaking and taxation as barriers or incentives for wind are not changed.

To check the effect of inflation, we ran all of the cases using a $4 \%$ inflation rate, as opposed to $0 \%$ (constant dollars) for the reference cases. The results for the wind technology and the coal plant are shown in Tables 5.6 and 5.7. There was very little effect from inflation on any of the tax or ratemaking policies. The effect from property taxes was significant until it was realized that the model understated assessed property values under inflation. Net book value (the method used) is a good approximation of assessed value under constant dollars, but in inflationary times the value would be reassessed periodically. To model this in the property tax calculation, we increased the net book value by the amount of inflation since plant start-up. The results in Table 5.6 show a reduction in the effect of property taxes on cost from 1.31 to 1.29 .

The reason that there is little change in conclusions in all of the cases above is because we are not comparing costs of technologies with one another but, rather, 
examining the effects of ratemaking and taxation procedures on a given technology. Changes to the plant parameters effect the cases both with and without the tax or ratemaking policy. As Tables 5.6 and 5.7 show, conclusions about barriers and incentives drawn from the process used in this study are robust across wide values of the variables shown in Tables 3.1, 3.2, and 3.3.

An important ratemaking assumption derived from the assumptions in Sect. 3 is the effect of fuel costs on rates. In our scenarios dealing with fuel costs, we assume in the reference scenario that annual increases in fuel costs (Table 3.3) are passed along to the customer on an annual basis. In the alternative scenario for fuel adjustment clauses, payment of fuel cost increases lagged one year for ratemaking purposes. In both these scenarios, we assume that all fuel cost increases are ultimately borne by ratepayers.

To see the effect of this assumption on our results, we conducted a sensitivity study on the assumed increase of natural gas prices. As indicated in Table 3.3, gas prices are assumed to increase at an annual rate of $3.2 \%$. In our sensitivity study, we assume the same $3.2 \%$ growth in natural gas prices for the two technologies using natural gas (i.e., combustion turbine and combined cycle), but further assume that only $2.2 \%$ is allowed to be passed along to ratepayers with the remaining $1 \%$ being borne by stockholders. This is an extreme case because it implies that by the end of the plant's life, customers are only paying $75 \%$ of the total fuel cost.

The results of this sensitivity study are significant. For a combustion turbine plant, the levelized cost decreases by nearly $1 \mathrm{c} / \mathrm{kWh}$ because ratepayers are exposed to only $2.2 \%$ annual growth. However, because equity holders must now bear $1 \%$ of the annual natural-gas price increase, the IRR-equity for a combustion turbine declines from the commission-allowed $7.0 \%$ to a negative return. The total IRR (i.e., debt + equity) declines from $5.85 \%$ to $2.74 \%$. For a combined cycle plant, the same assumptions show that the levelized cost drops by 6 mils, the internal rate of return-equity drops from $7.0 \%$ to a negative return, and the total IRR declines from $5.91 \%$ to $2.94 \%$. 


\section{SIMULATION RESULTS FOR NONUTILITY GENERATORS}

\subsection{SUMMARY}

Because NUGs are not subject to rate-of-return regulation in a manner similar to IOUs, we oniy consider the effects of tax measures on NUGs. Therefore, levelized cost is not used as a decisionmaking criterion. Instead, we use the internal rate of return (IRR) as the primary criterion. This variable indicates the overall return of the project to its investors, both debt and equity holders. We also use the IRR for equity shareholders alone as another criterion. Hiowever, its changes are more extreme and are dependent on details of the financing structure of the NUG which are beyond the scope of this study. Both criteria are defined in more detail in Appendix $A$.

In Table 6.1 we show the results of the tax policy scenarios. A reference scenario was established which included all current tax policies. Subsequently each specific tax policy was removed from the reference scenario to find its effect. The numbers in Table 6.1 show the ratio of the criterion (IRR, IRR-Equity) with the tax policy to the criterion without the policy. In most cases, this is the value from the reference scenario divided by the value from the sensitivity scenario. (The alternative minimum tax (AMT) data in the table have the reference scenario in the denominator since it did not include this tax policy.) The raw values of the output criteria are in Appendix B. Many of the results directly parallel the results for utilities (Sect. 5).

The first variation to the reference case was to run each technology with no taxes or credits of any kind. The changes in the project IRR can be seen in Fig. 6.1. For conventionals, the net effect of taxes is to lower the IRR by roughly $40 \%$. Pienewables, on the other hand, have a more varied response to taxes. While hydro and waste wood biomass facilities show effects from taxes similar to those of converitional technologies, the other renewables are not as affected. Dedicated biomass and wind plants actually show a net positive impact from taxes (i.e., higher IRR). To see why, each tax policy must be analyzed in turn.

The effects of property taxes alone are shown next in Table 6.1. For the NUG scenarios, both the property taxes and the annual net cash flow (which defines the IRR) are functions of the capital-intensiveness of the technology. Consequently, loss of property taxes has roughly the same proportionate effect on the IRII of low capitalintensive and high capital-intensive technologies.

We next show the effect of taxes on the inputs to production (labor, energy, material, and land) in Table 6.1. There is some variation based partly on the capitalintensiveness of the project. The technologies with high ratios of capital to fuel or O\&M costs are less affected by the taxes on inputs.

State income tax effects were examined next. The change in IRR due to the $6 \%$ tax was small but positive for several renewables. The two that receive the production tax credit were affected the most. The contract price per $\mathrm{kWh}$ used to determine revenues of the NUG are based on the levelized cost from the IOU reference cases that provided the utility with a $7 \%$ return on equity. The $10 \mathrm{U}$ versions of these two technologies (wind 
Table 6.1

Surnmary of Tax Effects on

Internal Rate of Return and Internal Rate of Return-Equity, Nonutility Generators

(Ratio of IRRs of Case with Tax Policies to Case Without)

\begin{tabular}{|c|c|c|c|c|c|c|c|c|}
\hline Generating Type & $\begin{array}{l}1 \\
1 \\
1 \\
1 \\
1 \\
1 \\
1\end{array}$ & $\begin{array}{l}\text { Effect of } \\
\text { Including } \\
\text { All Taxes } \\
\text { and Cradis }\end{array}$ & $\begin{array}{c}\text { Effect of } \\
\text { Including } \\
\text { Property Taxes }\end{array}$ & $\begin{array}{l}\text { Effect of } \\
\text { Includling } \\
\text { Input Taxes }\end{array}$ & $\begin{array}{l}\text { Effect of Includ- } \\
\text { ing State } \\
\text { Income Taxes }\end{array}$ & $\begin{array}{l}\text { Effect of } \\
\text { Including } \\
\text { Federal Taxes } \\
\text { and Credits }\end{array}$ & $\begin{array}{c}\text { Effecl of } \\
\text { Including } \\
\text { Alfernative } \\
\text { Minimum Tax }\end{array}$ & \\
\hline & $i$ & & i & & & & 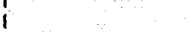 & \\
\hline RENEWABLES & i & & i & & & & i & 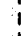 \\
\hline Biomass-Plantation & i & & i & & & & $!$ & ! \\
\hline Int. Rate of Rtrn & 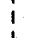 & 1.53 & 0.81 & 0.83 & 1.05 & 5.56 & 0.68 & $i$ \\
\hline IRR - Equity & 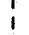 & 4.89 & 0.82 & 0.85 & 1.11 & a & 0.35 & ! \\
\hline Biomass-Waste & i & & $i$ & & & & $i$ & i \\
\hline Int. Rate of Rtrn & $i$ & $0: 71$ & 0.82 & 0.86 & 1.01 & 1.06 & 0.77 & 1 \\
\hline IRR - Equity & $i$ & 0.83 & 0.71 & 0.79 & 1.08 & 1.66 & 0.43 & r \\
\hline Geothermal & i & & 1 & & & & $\vdots$ & 1 \\
\hline Int. Rate of Rtrn & i & 0.82 & 0.81 & 0.87 & 1.02 & 1.29 & 0.75 & 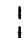 \\
\hline IRR - Equity & 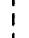 & 1.33 & 0.74 & 0.84 & 1.12 & 3.19 & 0,33 & i \\
\hline Hydro & 1 & & 1 & & & & $\vdots$ & 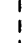 \\
\hline Int. Rate of Rirn & $i$ & 0.71 & 0.83 & 0.93 & 1.00 & 0.99 & 0.91 & i \\
\hline IRR - Equity & i & 0.57 & 0.66 & 0.86 & 1.01 & 1.07 & 0.77 & i \\
\hline Solar-Photovoltaic & 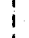 & & 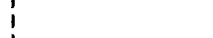 & & & & 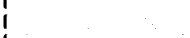 & i \\
\hline Int. Rate of Rtrn & i & 0.90 & 0.79 & 0.92 & 1.02 & 1.38 & 0.71 & I \\
\hline IRR - Equity & 1 & 2.12 & 0.73 & 0.92 & 1.16 & 5.53 & 5.32 & $i$ \\
\hline Solar-Thermal & $i$ & & 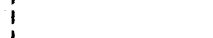 & & & & 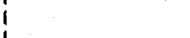 & i \\
\hline Int. Rate of Rtrn & $\begin{array}{l}1 \\
1\end{array}$ & 0.89 & 0.79 & 0.91 & 1.02 & 1.38 & 0.71 & 1 \\
\hline IRR - Equity & 1 & $2: 07$ & 0.73 & 0.90 & 1.16 & 5.44 & 5.17 & I \\
\hline Wind & i & & $i$ & & & & 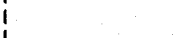 & i \\
\hline Int. Rate of Rtrn & 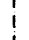 & 1.35 & 0.75 & 0.88 & 1.06 & 3.58 & 0.65 & 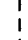 \\
\hline IRR - Equity & 1 & 5.91 & 0.71 & 0.86 & 1.20 & a & $\mathrm{a}$ & 1 \\
\hline & i & & $i$ & & & & 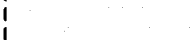 & i \\
\hline CONVENTIONAL & 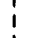 & & 1 & & & & i & 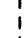 \\
\hline Coal & 1 & & 1 & & & & i & $i$ \\
\hline Int. Rate of Rtrn & $i$ & 0.64 & 0.84 & 0.87 & 0.99 & 0.93 & 0.97 & $\mathrm{i}$ \\
\hline IRR - Equity & $i$ & 0.49 & 0.69 & 0.77 & 0.99 & 0.93 & 0.91 & I \\
\hline Combined Cycle & i & & 1 & & & & $\vdots$ & i \\
\hline Int. Rate of Rirn & 1 & 0.56 & 0.80 & 0.83 & 0.99 & 0.90 & 0.98 & 1 \\
\hline IRR - Equity & $i$ & 0.45 & 0.68 & 0.75 & 0.98 & 0.85 & 0.95 & 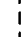 \\
\hline Combustion Turbine & 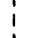 & & 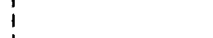 & & & & 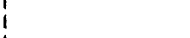 & 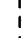 \\
\hline Int. Rate of Rtrn & 1 & 0.56 & 0.78 & 0.83 & 0.99 & 0.96 & 0.94 & $\vdots$ \\
\hline IRR - Equity & i & 0.45 & 0.64 & 0.75 & 1.00 & 1.01 & 0.86 & $\vdots$ \\
\hline Nuclear & $i$ & & $i$ & & & & 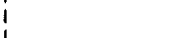 & I \\
\hline Int. Rate of Rirn & 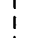 & 0.67 & 0.85 & 0.87 & 0.99 & 0.96 & 0.94 & i \\
\hline IRR - Equity & i & 0.55 & 0.71 & 0.77 & 1.00 & 1.01 & 0.85 & 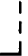 \\
\hline
\end{tabular}

Ratios greater than 1.0 indicate incentives; ratios less than 1.0 indicate barriers.

a Internal Rate of Return-Equity cannot be calculated for these cases because the equity cash flow profile is such that no discount rate will give a zero net present value over the entire life of the project. 
Figure 6.1

Effect of All Taxes and Credits on IRR, Nonutility Generators

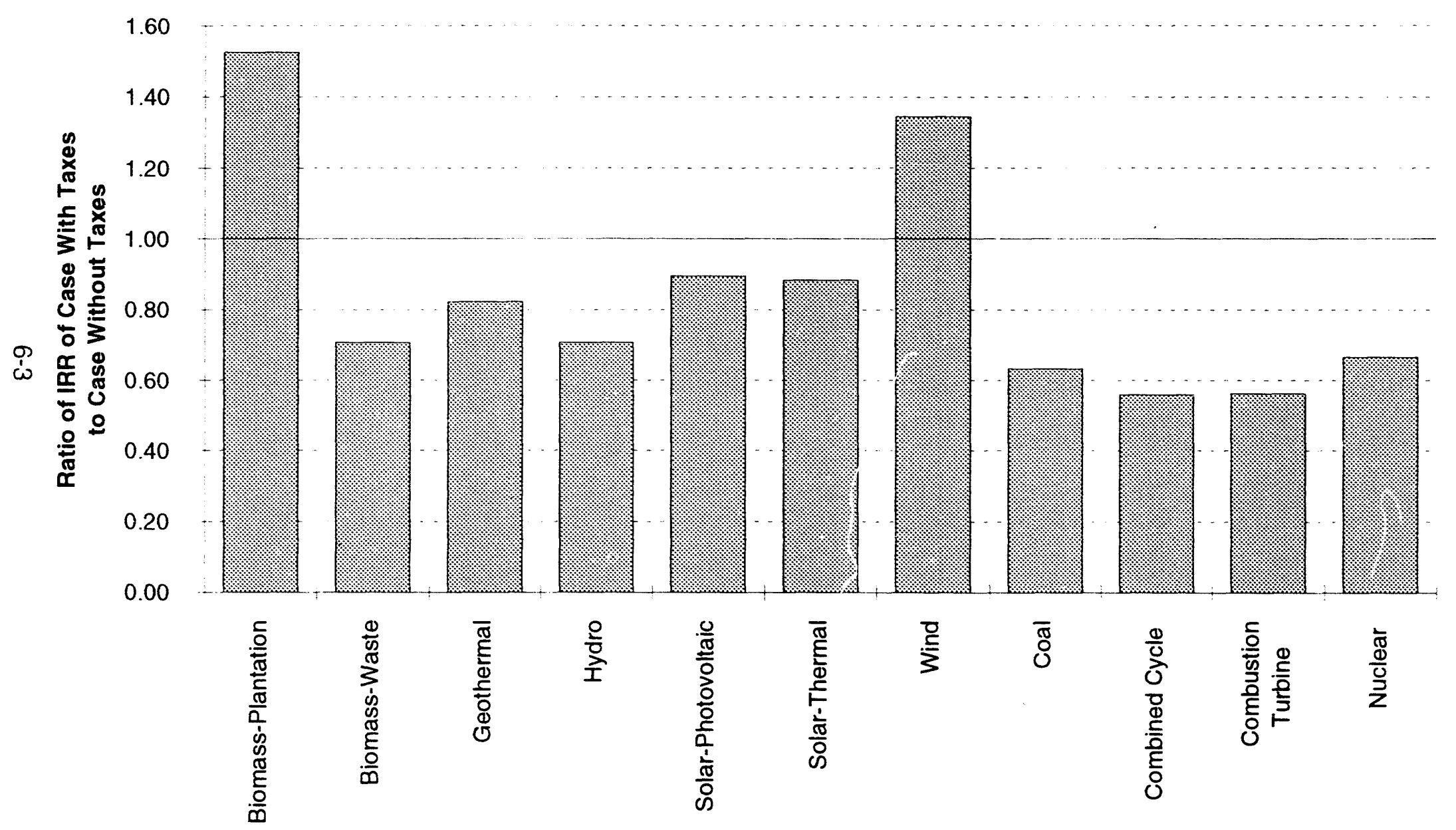

Ratios greater than 1.0 indicate incentives; ratios less than 1.0 indicate barriers. 
and biomass plantation) received that return after using the credit to boost earnings. This means that their pre-tax income was quite low or negative, resulting in tax losses which lowered their taxes. The NUGs similarly show tax losses in the early years, resulting in negative income taxes for these projects in those years. Removing the state or federal income tax eliminates those early tax benefits and lowers the IRR.

The next tax scenario had to do with federal income tax policies. By eliminating both income taxes and credits from the reference scenario, we could determine the net effect of federal income taxes (Fig. 6.2). The impact on the renewable technologies is quite dramatic. The production and energy investment credits in combination with accelerated depreciation cause IRRs to be $30 \%$ to $400 \%$ higher than without taxes and credits. The details behind these results are discussed in more detail in Sect. 6.2.1.

Last, the impact of the AMT was analyzed. Under this law taxpayers must calculate their taxes both using the regular rate and using a lower rate but without as many tax breaks. They must then pay the higher of the two. This serves to lower the near-term benefit of accelerated depreciation, greatly reducing the IRR of the renewables with 5-year tax lives (Fig. 6.3). This policy is examined in more detail in Sect. 6.2.2.

\subsection{KEY TAX EFFECTS}

Only some of the tax effects studied had a major differentiating impact on the costs of the technologies. Of those studied, the various facets of federal income tax policy were most significant. Tax depreciation lives and the availability of tax credits seemed to be the most crucial factors. The AMT also had a large effect.

\subsubsection{Federal Income Taxes and Credits}

As shown in Fig. 6.2, federal tax policies play a large role in the profitability of the renewable energy technologies. There are two main factors that create this differential in profitability: accelerated depreciation and tax credits. Table 6.2 lists the results of modifying each of these parameters separately and together. In Fig. 6.4, we show the clebt plus equity cash flow for the dedicated biomass plant under a set of sensitivities. As described in Appendix A, the IRR that we use as our criterion is the discount rate that makes the net present value of the cash flow equal zero.

The reference scenario includes both the production tax credit and the 5-year depreciation life, as well as a $35 \%$ income tax rate. It has the highest near-term positive cash flow because of these factors and a consequent IRR of $7.9 \%$. Without accelerated depreciation, the cash flow curve shows a smaller, flat increase for the 10 years that the production tax credit is available. Its IRR is $6.1 \%$. With no tax credit, there is an even smaller rise in the early years, which disappears at the end of the tax depreciation life. Its IRR is $2.9 \%$. When neither the accelerated depreciation nor credit is available, the cash flow is essentially flat because slowly declining property taxes are offset by slowly increasing income tax payments; all other cash flows are constant. The IRR becomes $2.1 \%$. 


\section{Figure 6.2}

Effect of Federal Taxes and Credits on IRR,

Nonutility Generators

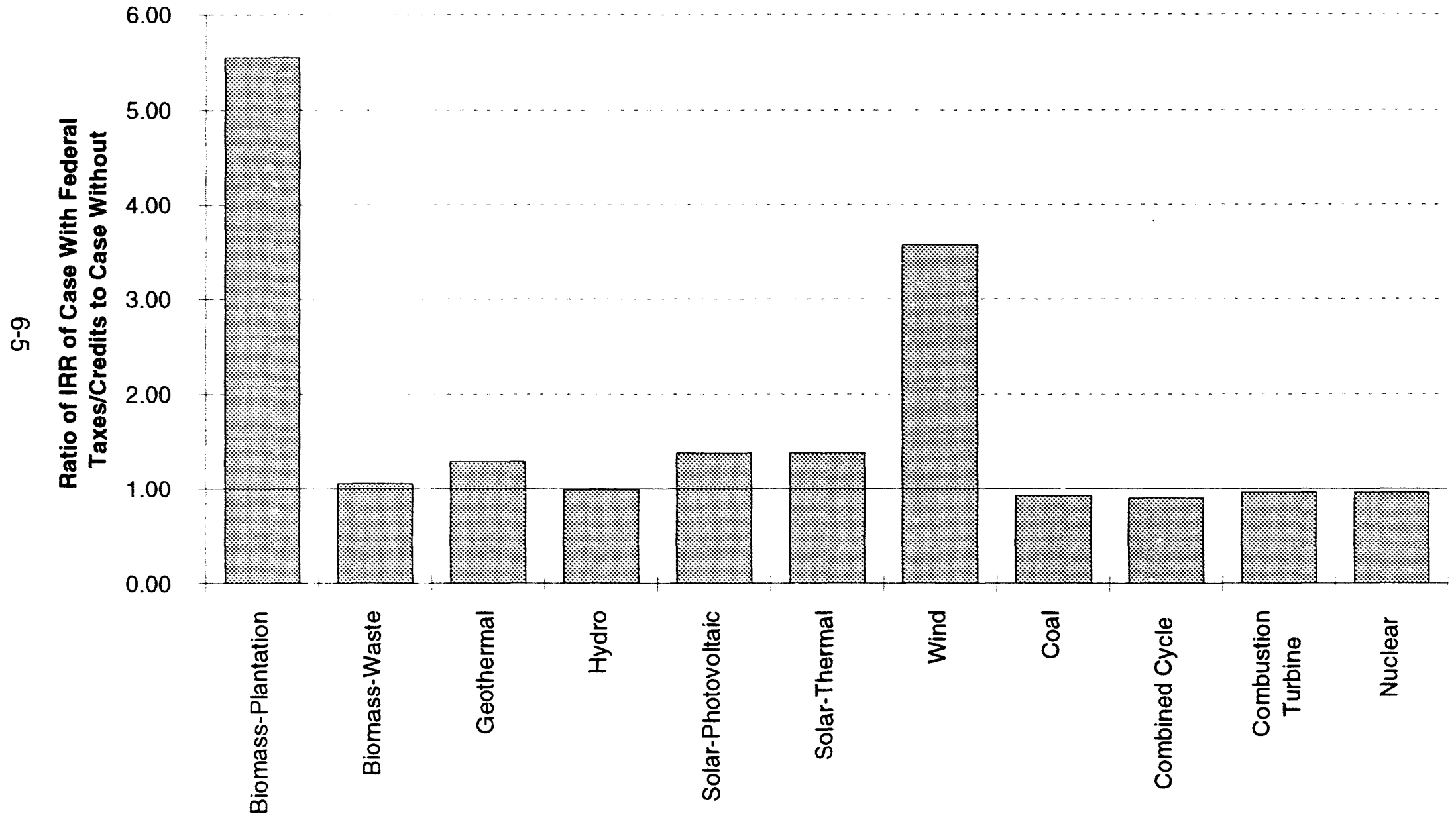

Ratios greater than 1.0 indicate incentives; ratios less than 1.0 indicate barriers. 
Figure 6.3

Effect of Alternative Minimum Tax on IRR, Nonutility Generators

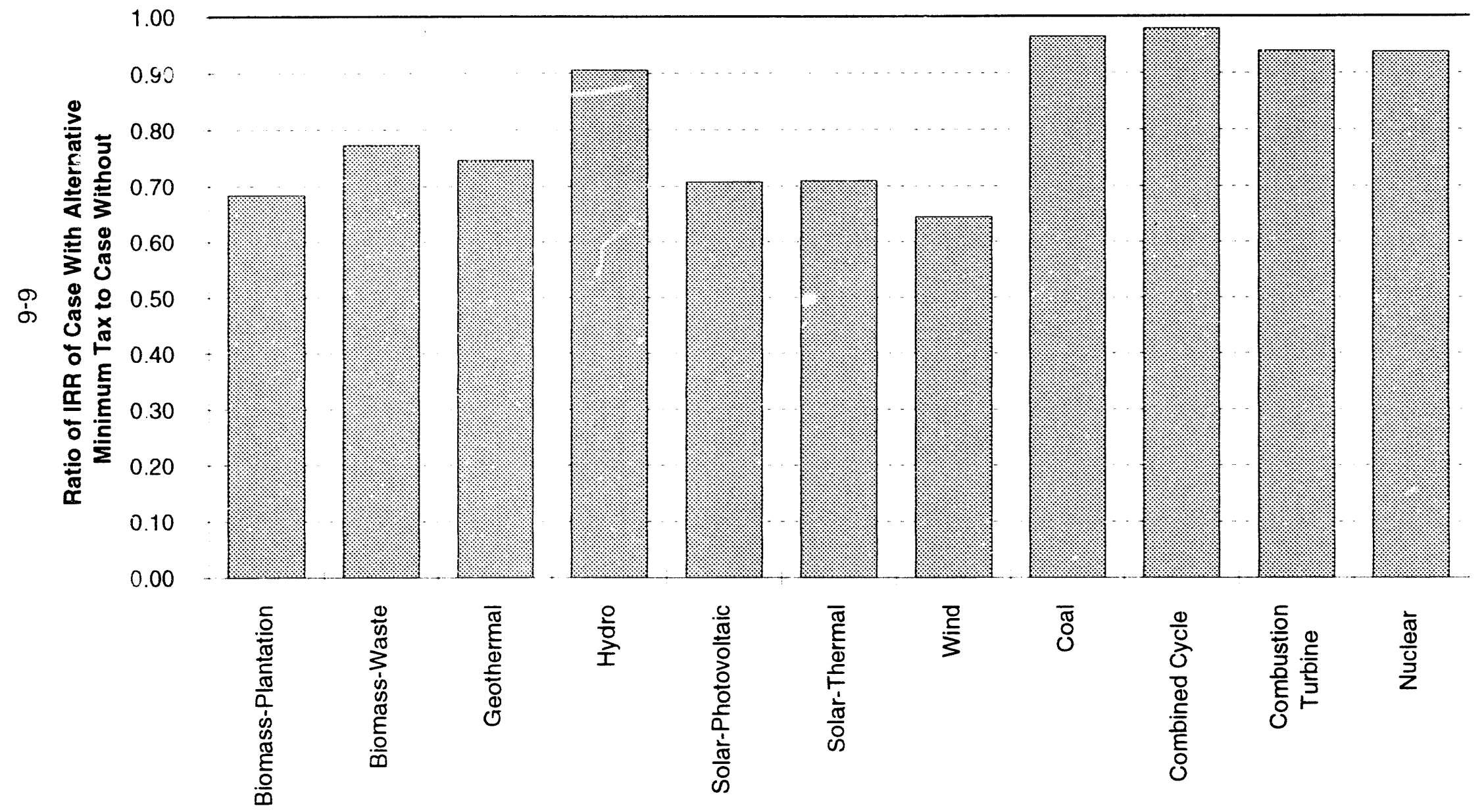

Ratios greater than 1.0 indicate incentives; ratios less than 1.0 indicate barriers. 
Table 6.2

Summary of Federal Income Tax Effects on

Internal Rate of Return and Internal Rate of Return-Equity, Nonutility Generators

(Ratio of IRRs of Case with Tax Pollcles to Case Without)

\begin{tabular}{|c|c|c|c|c|}
\hline Generating Type & $\begin{array}{c}\text { Effect of } \\
\text { Including } \\
\text { Income Taxes } \\
\text { and Credits }\end{array}$ & $\begin{array}{l}\text { Effect of } \\
\text { Including } \\
\text { Accelerated } \\
\text { Depreciation }\end{array}$ & $\begin{array}{l}\text { Effect of } \\
\text { Including } \\
\text { Federal } \\
\text { Tax Credits }\end{array}$ & $\begin{array}{c}\text { Effect of Including } \\
\text { Accelerated } \\
\text { Depreciation and } \\
\text { Tax Credits }\end{array}$ \\
\hline RENEWABLES & . & & & \\
\hline \multicolumn{5}{|l|}{ Biomass-Plantation } \\
\hline Int. Rate of Retrn & 5.50 & 1.30 & 2.75 & 3.58 \\
\hline IRR-Equity & $\mathbf{a}$ & 2.47 & $a$ & $a$ \\
\hline \multicolumn{5}{|l|}{ Biomass-Waste } \\
\hline Int. Rate of Retrn & 1.06 & 1.24 & 1.00 & 1.24 \\
\hline IRR-Equity & 1.66 & 2.25 & 1.00 & 2.25 \\
\hline \multicolumn{5}{|l|}{ Geothermal } \\
\hline Int. Rate of Retrn & 1.29 & 1.26 & 1.16 & 1.75 \\
\hline IRR-Equity & 3.19 & 2.76 & 1.74 & 8.95 \\
\hline \multicolumn{5}{|l|}{ Hydro } \\
\hline Int. Rate of Retrn & 0.99 & 1.11 & 1.00 & 1.11 \\
\hline IRR-Equity & 1.07 & 1.34 & 1.00 & 1.34 \\
\hline \multicolumn{5}{|l|}{ Solar-Photovoltaic } \\
\hline Int. Rate of Retrn & 1.38 & 1.30 & 1.19 & 1.53 \\
\hline IRR-Equity & 5.53 & 4.37 & 2.27 & 7.53 \\
\hline \multicolumn{5}{|l|}{ Solar-Thermal } \\
\hline Int. Rate of Retrn & 1.38 & 1.30 & 1.19 & 1.53 \\
\hline IRR-Equity & 5.44 & 4.33 & 2.25 & 7.41 \\
\hline \multicolumn{5}{|l|}{ Wind } \\
\hline Int. Rate of Retrn & 3.58 & 1.31 & 2.03 & 2.63 \\
\hline IRR-Equity & $\mathbf{a}$ & 5.58 & $a$ & $a$ \\
\hline \multicolumn{5}{|l|}{ CONVENTIONAL } \\
\hline \multicolumn{5}{|l|}{ Coal } \\
\hline Int. Rate of Retrn & 0.93 & 1.06 & 1.00 & 1.06 \\
\hline IRR-Equity & 0.93 & 1.19 & 1.00 & 1.19 \\
\hline \multicolumn{5}{|l|}{ Combined Cycle } \\
\hline Int. Rate of Retrn & 0.90 & 1.08 & 1.00 & 1.08 \\
\hline IRR-Equity & 0.85 & 1.28 & 1.00 & 1.28 \\
\hline \multicolumn{5}{|l|}{ Combustion Turbine } \\
\hline Int. Rate of Retrn & 0.96 & 1.15 & 1.00 & 1.15 \\
\hline IRR-Equity & 1.01 & 1.72 & 1.00 & 1.72 \\
\hline \multicolumn{5}{|l|}{ Nuclear } \\
\hline Int. Rate of Retrn & 0.96 & 1.09 & 1.00 & 1.09 \\
\hline IRR-Equity & 1.01 & 1.27 & 1.00 & 1.27 \\
\hline
\end{tabular}

Ratios greater than 1.0 indicate incentives; ratios less than 1.0 indicate barriers.

a Internal Rate of Retum-Equity cannot be calculated for these cases because the equity cash flow profile is such that no discount rate will give a zero net present value over the entire life of the project. 


\section{Figure 6.4}

Effect of Federal Tax Policies on

Annual Debt and Equity Cash Flow, NUG Biomass Plantation

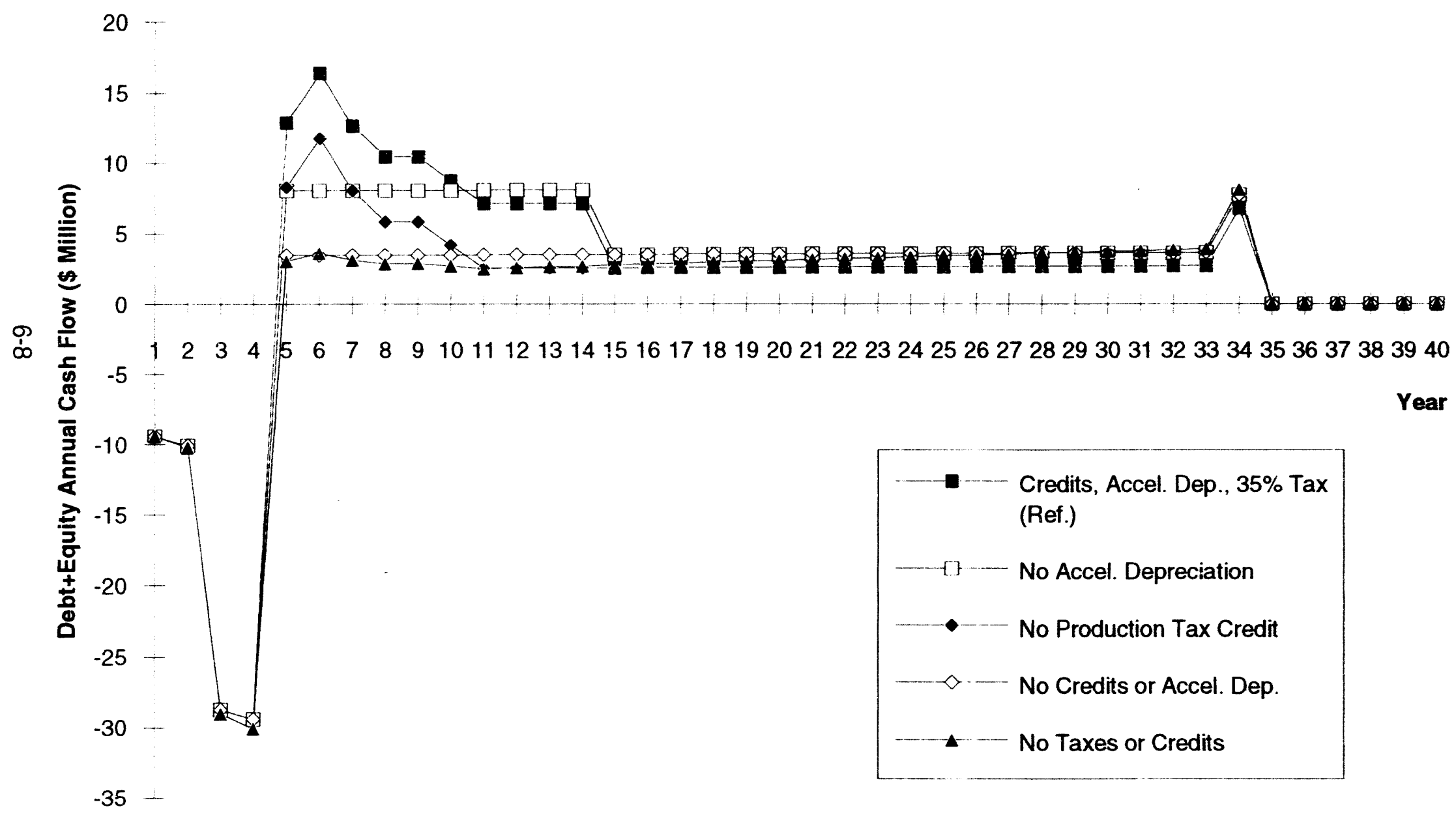


What is surprising is that with no taxes or credits, meaning the income tax rate and credits are both zero, the IRR becomes even worse, at $1.4 \%$. This is because the price used, which is what the plant would cost utility customers if it were utility-owned, was based on the utility's receiving these tax benefits. When the NUG must charge a price that gives it only a fair return (7.9\%) after various tax credits are included, it is actually losing money on a tax basis before the credits. Consequently, income taxes are a net positive cash flow; the income tax calculation shows operating losses that the owner can use to lower his taxes on other income.

In Table 6.2 we show the effect of accelerated depreciation alone on each of the technology's IRRs. As expected, those with a 5-year depreciation schedule (biomass, geothermal, solar, and wind) receive the most benefit. Table 6.2 also displays the effects of the tax credits. The production tax credit (on dedicated biomass and wind) has the largest impact, more than doubling the IRR. (Both technologies have prices below the $86 / \mathrm{kWh}$ threshold, so they can use the full 1.56 credit.) The energy investment credit raises the IRR by roughly $20 \%$.

\subsubsection{Alternative Minimum Tax Effects}

The AMT is designed to prevent taxpayers from avoiding tax liabilities because of certain tax benefits. Sect. 4.2 .8 describes the tax methodology in more detail. The result of applying the AMT is that taxes are higher in the early years of the plant's life, lowering the debt and equity cash flow. This lowers the IRR for the project. In Fig. 6.3, we show that the effect is most pronounced on the renewable energy technologies that have a 5year tax depreciation life. The AMT increases the life to 12 years and uses a less advantageous method for calculating depreciation.

As an example, in Fig. 6.5 we show the annual debt plus equity cash flow for the wind technology under the reference scenario and after applying the AMT. Taxes are higher with the AMT in years 3 through 8 , costing the investors a total of almost $\$ 12$ million. After year 8 , the regular tax calculation results in a higher tax amount and so is paid in both cases. The net result is a lowering of the IRR from $6.5 \%$ to $4.2 \%$.

As a variant on the AMT, we also ran a scenario in which the owners did not have other income with which they could offset the tax losses from the generating facility. Since the government will not pay negative taxes in the case of operating losses, the company must use the losses to offset profits either in earlier or future years. This is called carryback or carryforward of losses, respectively. This topic is discussed in more detail in Sect. 4.2.8.

In Table 6.3, we show the results for the reference scenario, the AMT scenario, the carryforward scenario, and the AMT plus carryforward scenario. Carryforward most dramatically affects the technologies that have tax credits available. Since there must be positive taxes with which to offset the credits, the owners cannot use the credits until the previous tax losses are offset by positive taxes. This delays the time when they are taken and thus reduces their present value. In the case of dedicated biomass and wind (with the production tax credit), some of the tax credits are never used because of the lack of sufficient offsetting taxes. 


\section{Figure 6.5}

Effect of Alternative Minimum Tax on

Annual Debt and Equity Cash Flow,

NUG Wind Plant

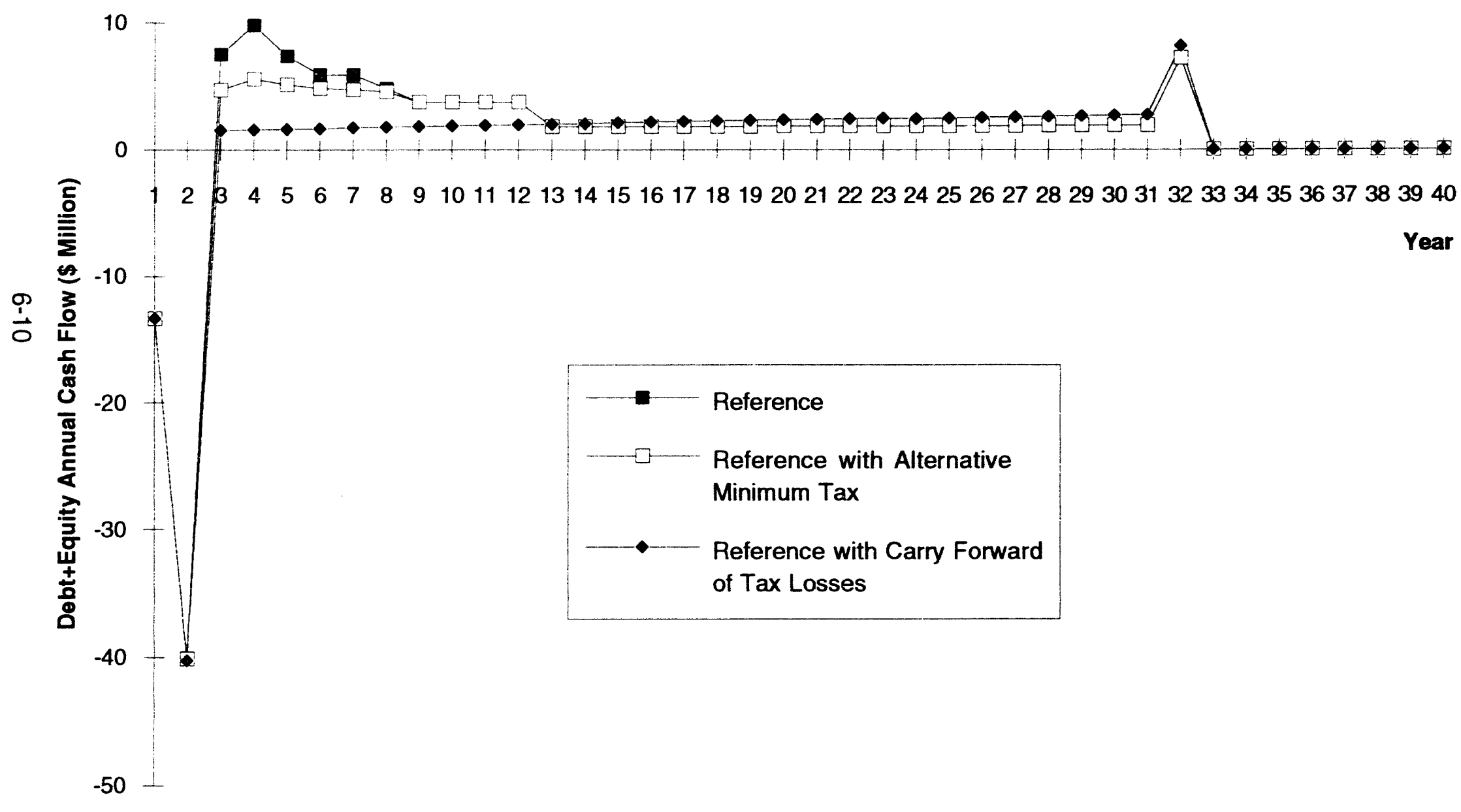




\section{Table 6.3 \\ Summary of Alternative Minimum Tax Effects on Internal Rate of Return and Internal Rate of Return-Equity, Nonutility Generators \\ (Ratio of IRRs of Case with Tax Policles to Case Without)}

\begin{tabular}{|c|c|c|c|}
\hline $\begin{array}{l}\text { GENERATING } \\
\text { ALTERNATIVE }\end{array}$ & $\begin{array}{l}\text { Effect of Including } \\
\text { Alternative } \\
\text { Minimum Tax }\end{array}$ & $\begin{array}{c}\text { Effect of Including } \\
\text { Carrytorward } \\
\text { of Tax Losses }\end{array}$ & $\begin{array}{c}\text { Effect of Including } \\
\text { AMT and } \\
\text { Carrytorward of Losses }\end{array}$ \\
\hline \multicolumn{4}{|l|}{ RENEWABLES } \\
\hline Int. Rate of Retrn & 0.68 & 0.14 & 0.14 \\
\hline IRR-Equity & 0.35 & a & a \\
\hline \multicolumn{4}{|l|}{ Blomass-Waste } \\
\hline Int. Rate of Retrn & 0.77 & 0.84 & 0.74 \\
\hline IRR-Equity & 0.43 & 0.49 & 0.37 \\
\hline \multicolumn{4}{|l|}{ Geothermal } \\
\hline Int. Rate of Hetrn & 0.75 & 0.72 & 0.65 \\
\hline IRR-Equity & 0.33 & 0.26 & 0.19 \\
\hline \multicolumn{4}{|l|}{ Hydro } \\
\hline Int. Rate of Retrn & 0.91 & 0.92 & 0.89 \\
\hline IRR-Equity & 0.77 & 0.79 & 0.73 \\
\hline \multicolumn{4}{|l|}{ Solar-Photovoltaic } \\
\hline Int. Rate of Retrn & 0.71 & 0.66 & 0.60 \\
\hline IRR-Equity & a & 0.14 & a \\
\hline \multicolumn{4}{|l|}{ Solar-Thermal } \\
\hline Int. Rate of Retrn & 0.71 & 0.66 & 0.60 \\
\hline IRR-Equity & $a$ & 0.14 & a \\
\hline \multicolumn{4}{|l|}{ Wind } \\
\hline Int. Rate of Retrn & 0.65 & 0.24 & 0.24 \\
\hline IRR-Equity & $a$ & a & a \\
\hline \multicolumn{4}{|l|}{ CONVENTIONAL } \\
\hline \multicolumn{4}{|l|}{ Coal } \\
\hline Int. Rate of Retrn & 0.97 & 0.98 & 0.96 \\
\hline IRR-Equity & 0.91 & 0.93 & 0.89 \\
\hline \multicolumn{4}{|l|}{ Combined Cycle } \\
\hline Int. Rate of Retrn & 0.98 & 1.00 & 0.98 \\
\hline IRR-Equity & 0.95 & 0.99 & 0.94 \\
\hline \multicolumn{4}{|l|}{ Combustion Turbine } \\
\hline Int. Rate of Retrn & 0.94 & 0.98 & 0.94 \\
\hline IRR-Equity & 0.86 & 0.93 & 0.85 \\
\hline \multicolumn{4}{|l|}{ Nuclear } \\
\hline Int. Rate of Retrn & 0.94 & 0.94 & 0.92 \\
\hline IRR-Equity & 0.85 & 0.83 & 0.79 \\
\hline
\end{tabular}

Ratios greater than 1.0 indicate incentives; ratios less than 1.0 indicate barriers.

a Internal Rate of Return-Equity cannot be calculated for these cases because the equity cash flow profile is such that no discount rate will give a zero net present value over the entire life of the projer 
In Fig. 6.5 we include the annual cash flow from the carryforward scenario for the wind technology. In this case, over $\$ 13$ million of credits are lost because of the lack of offsetting taxes. In addition, $\$ 15$ million in taxes on operating losses from the early years are lost. They cannot be used to offset positive taxes before the 15-year time limit is over. The net effect is a decline in the wind IRR from $6.5 \%$ to $1.5 \%$. With the AMT in effect as well as carryforward, the IRR stays the same as with carry-forward alone. Net federal taxes remain zero in both cases. With the AMT there are fewer tax credits from operating losses that get lost because they are not used within 15 years. Instead of $\$ 15$ million lost, only $\$ 3$ million are lost. 


\section{DETERMINING RELATIVE BARRIERS AND INCENTIVES}

In Sections 2 through 6, we laid the foundation for answering questions posed by Section 1205 of the Energy Policy Act of 1992 (EPACT) by (1) quantifying basic financial and technical parameters of seven renewable and four conventional electric generating technologies, (2) identifying applicable tax measures and ratemaking procedures for investor-owned utilities (IOUs) and nonutility generators (NUGs), and (3) simulating the effects of changing these measures and procedures on the financial criteria used by IOUs and NUGs for making generation resource decisions. The results of the simulations identify tax and ratemaking barriers and incentives for individual technologies. In this section, we take the analysis one step further by determining whether the barriers and incentives defined in Sections 5 and 6 for renewable technologies are significantly greater than for conventional ones. Or, in the words of Section 1205 of EPACT, we determine "if conventional taxation and ratemaking procedures result in economic barriers to or incentives for renewable energy power plants compared to conventional power plants." (Emphasis supplied.)

Before proceeding to a discussion of the results of that comparison, however, in Sections 7.1 and 7.2 we place this study in the context of power-plant decisionmaking by addressing factors other than financial attractiveness that affect decisions on technology adoption by IOUs and NUGs. Three factors are especially important. First, we discuss the influence of integrated resource planning (IRP) on an IOU's technology-adoption decisions. Second, we discuss technical and financial risk, risk-bearers, and the influence of risk on decisionmaking. Finally, we mention public policies toward renewable and conventional generating technologies, which may encourage the use of certain technologies by reducing their technical and/or financial risk. We present a qualitative discussion of these three factors because it is not possible to quantify their effects on technology adoption even though they are crucial in the decisionmaking process. Although the relative tax and ratemaking barriers and incentives presented in Section 7.3 are part of the financial determination of technology adoption, there are other important considerations that also shape decisionmaking on electric generating technology adoption.

\subsection{INTEGRATED RESOURCE PLANNING AND RESOURCE SELECTION}

The results of this study only indicate directions of financial attractiveness: barriers to--and incentives for--adopting renewable and conventional power plants. The results do not suggest which technologies will be adopted by IOUs or NUGs. In realworld settings, technologies are only cost (in)effective relative to a given power system. Technical factors such as availability, diversity, dispatchability, and reliability are also integral parts of the decisionmaking process, as are the technical and financial characteristics of competing supply and demand resource options.

Expanding on the latter point, many IOUs are looking to reduce demand as a way to meet energy and load requirements. That is, changing the pattern and level of electricity demand (i.e., demand-side management (DSM)) with conservation and load management strategies is considered a resource option along with traditional supply resources (e.g., building new generating statiuns, extendiny the life of old ones, or 
purchasing power from other sources). The process of selecting a resource mix on the basis of comparing the benefits and costs of all demand and supply options is referred to as IRP. The IRP process is an integration of (1) traditional least-cost planning, a process by which utilities minimize the cost of generating a given amount of electricity, (2) demand-side planning, and (3) other relevant factors. IRP gives the electric utility more options to consider in developing its resource strategy.

In this study, we did not model this complex decisionmaking process which varies from state to state and utility to utility. Rather, we estimated the relative impact of certain tax measures and ratemaking procedures on financial criteria that IOUs and NUGs use as inputs to make technology-adoption decisions. Where these tax measures and ratemaking procedures provide incentives for an alternative, however, they increase the likelihood that the alternative will be selected by IOUs or NUGs when making generatingresource decisions.

\subsection{RISK, PUBLIC POLICY, AND RESOURCE SELECTION}

The seven renewable and four conventional technologies considered in this study share common characteristics. They each require capital, labor, energy, and materials for their construction and also require, to varying degrees, labor, energy, and materials for their operation. From these shared characteristics, the technologies diverge markedly in technical and financial characteristics and public policy treatment. In this study, we did not provide a taxonomy of all of these technical/financial and policy differences for the 11 technologies. In the following paragraphs, however, we will identify important differences and identify how they influence the decisionmaking process.

Given the differences in technical and financial characteristics of the 11 generating technologies considered in this study, it follows that there are differences in technical and financial risks associated with using the technologies. An important factor taken into consideration by IOUs and NUGs when making technology-adoption decisions is the allocation of these risks among affected parties.

One important consideration in adopting a generating technology is the risk that the technology will not be able to perform its assigned work load in a power delivery system because of operating constraints. As an example, hydroelectric plants require substantial amounts of rain or snow annually. For hydroelectric plants, an important consideration is the party bearing the financial risk of providing power from alternative sources in the event of a drought. If redundant capacity must be constructed to hedge against a drought or power must be purchased to replace a hydro shortfall, the party that is expected to bear the increased cost has higher risk. If rainfall is larger than expected and there is a surplus of hydropower, the party bearing the risk may experience a windfall.

A further distinction in the financial risk of adopting renewable versus conventional technologies concerns the capital and fuel intensity of generating technologies. In evaluating technologies, analysts necessarily project future capital and operating costs. There will be a bias for or against adopting a generating technology depending on the party bearing the risk that costs may differ from projections made at the time that the 
technology is selected. For example, a fossil fuel-intensive technology is more attractive to a decisionmaker if the decisionmaker does not bear the risk of fuel-price fluctuations. Therefore, the ratemaking procedure of passing through the risk of fuel-price fluctuations to ratepayers favors fuel-consuming technologies. This is a barrier to the adoption of renewable technologies that are not subject to fuel-price fluctuations.

A similar argument can be made for construction costs that differ from those projected at the time that the technology-adoption decision is made. If the out-of-pocket construction costs of a generating plant are greater than forecasted, who bears the cost? If construction costs are less than projected, who reaps the benefits?

The distribution of these risks among parties is typically determined by regulatory authorities in the ratemaking process. For example, fuel costs higher than expected at the time of technology-adoption decisions are typically borne by ratepayers. The benefits of fuel costs less than expected are also typically reaped by ratepayers. Construction costs are typically subject to prudence reviews. If actual construction costs exceed projected amounts by a large margin, some regulatory authorities have required costsharing--i.e., ratepayers bear part of the excess cost along with investors. The benefits of construction costs less than projected are typically reaped by ratepayers.

Like the IRP paradigm discussed in the previous section, these technical and financial risks--and the parties bearing them--are important considerations for decisionmakers when making technology-adoption choices. However, it is extremely difficult to quantify the effects that these risks have on technology choices in terms of the financial criteria that we used. We made no attempt to do so in this study.

Although historical and current policy measures that affect development and adoption of electric generating technologies are beyond the scope of Section 1205 of EPACT, for completeness we mention some of these measures below.

Publicly owned utilities (POUs) were excluded from this study because they are not subject to federal taxes and ratemaking procedures in the same manner as lOUs. POUs may have a bias for capital-intensive technologies (such as renewable ones) because of capital subsidies available to them. Also, current and historical subsidies for some electric-generating fuels make technologies that use these fuels more attractive than they otherwise would be in the absence of those subsidies. By not analyzing entire fuel cycles, we do not capture the potential bias for these fuel-intensive technologies. Similarly, we did not address current and historical public R\&D subsidies for development of energy technologies, including both renewable and conventional electric generating technologies.

In this study, we examined a particular set of tax measures and ratemaking procedures as prescribed by Section 1205 of EPACT. These measures and procedures provide barriers and incentives to technology adoption and their appropriateness should be examined closely by federal and state regulatory authorities. Further study is iequired to examine the barriers and incentives for technology adoption beyond those considered in this study and discussed in the next section. 


\subsection{RATEMAKING AND TAXATION BARRIERS AND INCENTIVES}

In this study, we estimated the differential effects of current tax measures and ratemaking procedures on the financial criteria that IOUs and NUGs use to make decisions on adopting electric generating technologies. The purpose of estimating these effects is to determine whether the taxation and ratemaking procedures result in barriers to or incentives for the adoption of renewable generating technologies compared to conventional ones. For IOUs, the technology's levelized cost is the primary criterion. For NUGs, the primary criterion is the internal rate of return (IRR).

Because the enabling legislation for this study (Section 1205 of EPACT) limits its scope to decisions on renewable vs. conventional generating plants, no attempt was made to examine tax policies outside of those that apply to decisions on generating plants. ${ }^{1}$

In Sections 5 and 6, taxation and ratemaking 'barriers' to and 'incentives' for adopting technologies are defined in terms of their effects on values of the decisionmaking criteria. For example, using the primary financial criterion for lOUs, if a tax measure or ratemaking procedure results in a lower levelized cost for any of the technologies measured from the reference case, the procedure is an incentive for adopting the technology. Conversely, if the levelized cost is higher, the procedure is a barrier. Likewise for NUGs, if a tax measure ${ }^{2}$ results in a higher IRR, the tax is an incentive for adopting the technology. If the return is lower, it is a barrier to adoption.

However, Section 1205 of EPACT requires more than just determining whether or not a measure or procedure is a barrier or incentive. It specifically states a determination must be made as to whether the measures and procedures are barriers and incentives "for renewable energy power plants compared to conventional power plants." Therefore, in the following tables we compare the effects of the tax measures and ratemaking procedures on renewable technologies to the effects on conventional ones. If the measure or procedure benefits a renewable technology more than conventional technologies, it is an incentive (I) for the renewable technology. Conversely, if the measure or procedure benefits conventional technologies more than the renewable technology, it is a barrier (B) to the renewable technology. We use information from Sections 5 and 6 to make this determination.

We summarize the results on barriers (Bs) to and incentives (Is) for adoption of each of the renewable technologies under all tax measures and ratemaking procedures considered in this study for IOUs in Table 7.1. We provide similar results for NUGs in Table 7.2. Differences in the two tables reflect the fact that NUGs are more likely to be subject to the alternative minimum $\operatorname{tax}(A M T)$ than IOUs and they are not subject to the

\footnotetext{
${ }^{1}$ For the interested :eader, however, Section 3015 of EPACT requires the National Academy of Sciences to conduct a broajer study on energy subsidies which presumabiv will address tax policies other than those affecting decisions on technology-adoption.

${ }^{2}$ Note that ratemaking procedures do not apply to NUGs.
} 
Table 7.1

Barriers To and Incentives For Renewable Technologies

Comparison With Conventional Technologies

Investor-Owned Utilities

\begin{tabular}{lccc}
\hline $\begin{array}{l}\text { Measure/ } \\
\text { Procedure }\end{array}$ & $\begin{array}{c}\text { Biomass } \\
\text { Plantation }\end{array}$ & $\begin{array}{c}\text { Biomass } \\
\text { Waste Geothermal Hydro }\end{array}$ & $\begin{array}{c}\text { Solar Solar } \\
\text { PV Thermal Wind }\end{array}$ \\
\hline
\end{tabular}

\section{Taxation Effects:}

All Taxes

Local Property Taxes

Taxes on Inputs

State Income Taxes

Federal Income Taxes ${ }^{\mathrm{a}}$

Accelerated Depreciation ${ }^{b}$

Federal Tax Credits $^{c}$

$\begin{array}{ccc}1 & - & - \\ - & - & - \\ - & - & - \\ i & - & - \\ - & - & 1 \\ \text { i } & \text { NA } & \text { NA }\end{array}$

$\begin{array}{cccc}\text { B } & \text { B } & - & \text { I } \\ \text { B } & \text { B } & \text { B } & \text { B } \\ - & - & - & - \\ - & - & - & - \\ - & 1 & 1 & 1 \\ \text { I } & 1 & 1 & 1 \\ \text { NA } & \text { NA } & \text { NA } & 1\end{array}$

\section{Ratemaking Effects:}

No CWIP in the Rate Base

Tax Normalization

Fuel Adjustment Clauses

\section{SOURCES: Tables C.1 and C.2 in Appendix C.}

$A$ ' $B$ ' indicates that the tax measure or ratemaking procedure is a barrier to adopting the technology based on comparing the ratio of the measure's or procedure's effect with the average value of the ratios of conventional technologies. If the value of the ratio is more than five percent greater than the corresponding average value for conventional technologies, the measure or procedure is a barrier.

An 'I' indicates that the tax measure or ratemaking procedure is an incentive to adopting the technology based on comparing the ratio of the measure's or procedure's effect with the average value of the ratios of conventional technologies. If the value of the ratio is more than five percent less than the corresponding average value for conventional technologies, the measure or procedure is an incentive.

An 'NA' indicates that the measure is not applicable to the technology.

An ' - ' indicates that the measure or procedure is applicable, but the value of the ratio is within \pm five percent of the average for conventional technologies.

ancludes the effects of all federal income taxes, including accelerated depreciation, and federal production and investment tax credits.

bincludes the effects of accelerated depreciation exclusively.

Includes the effects of federal production and investment tax credits exclusively. 


\section{Table 7.2}

\section{Barriers To and Incentives For Renewable Technologies Comparison With Conventional Technologies Nonutility Generators}

\begin{tabular}{|c|c|c|c|c|c|c|c|}
\hline $\begin{array}{l}\text { Measure/ } \\
\text { Procedure }\end{array}$ & $\begin{array}{l}\text { Biomass } \\
\text { Plantation }\end{array}$ & $\begin{array}{l}\text { Biomass } \\
\text { Waste }\end{array}$ & Geothermal & Hydro & $\begin{array}{l}\text { Solar } \\
\text { PV }\end{array}$ & $\begin{array}{l}\text { Solar } \\
\text { Thermal }\end{array}$ & Wind \\
\hline All Taxes & 1 & 1 & 1 & 1 & 1 & 1 & 1 \\
\hline Local Property Taxes & - & - & - & - & - & - & B \\
\hline Taxes on Inputs & - & - & - & 1 & 1 & 1 & - \\
\hline State Income Taxes & 1 & - & - & - & - & - & 1 \\
\hline Federal Income Taxes & 1 & 1 & 1 & 1 & 1 & 1 & 1 \\
\hline Accelerated Depreciation ${ }^{b}$ & 1 & I & 1 & - & 1 & 1 & 1 \\
\hline Federal Tax Credits ${ }^{c}$ & $i$ & NA & i & NA & 1 & i & i \\
\hline Aternative Minimum Tax & B & B & B & B & B & B & B \\
\hline
\end{tabular}

SOURCE: Table C.3 in Appendix C.

$A$ ' $B$ ' indicates that the tax measure is a barrier to adopting the technology based on comparing the ratio of the measure's effect with the average value of the ratios of conventional technologies. If the value of the ratio is more than five percent less than the corresponding average value for conventional technologies, the measure a barrier.

An 'I' indicates that the tax measure is an incentive to adopting the technology based on comparing the ratio of the measure's effect with the average value of the ratios of conventional technologies. If the value of the ratio is more than five percent greater than the corresponding average value for conventional technologies, the measure is an incentive.

An 'NA' indicates that the measure is not applicable to the technology.

An ' - ' indicatis that the measure is applicable, but the value of the ratio is within \pm five percent of the average for conventional technologies.

ancludes the effects of all federal income taxes, including accelerated depreciation, and federal production and investment tax credits.

bincludes the effects of accelerated depreciation exclusively.

Includes the effects of federal production and investment tax credits exclusively.

dincludes the effects of the alternative minimum tax.

same ratemaking procedures as $10 \mathrm{Us}$.

As the notes to the tables indicate, a tax measure or ratemaking procedure for 
renewable technologies was determined to be a barrier or incentive to renewable technology adoption compared with conventional technologies if the financial ratios presented in Sections 5 and 6 differ by more than five percent points from the average of the four conventional technologies. The applicable values presented in Sections 5 and 6 are the ratios of the values of the financial indicators without the measure or procedure included to the values of the financial indicators with the measures or procedures. The five percentage point difference from the average values of the conventional technologies is presumed to be large enough to change the relative financial attractiveness of different technologies. ${ }^{3}$

From Table 7.1, taxes for lOUs at the state, local, and federal levels (i.e., 'all taxes') are incentives for two of the seven renewable technologies, and a barrier for hydro and solar PV. For NUGs (Table 7.2), 'all taxes' are incentives for all seven renewable technologies compared to conventional technologies. The primary reasons for these conclusions are the large financial benefits provided by accelerated depreciation and the production and investment tax credits, which do not apply to conventional technologies.

For lOUs, property taxes are barriers to the adoption of hydro, solar and wind technologies, compared to conventional technologies. For NUGs, property taxes are only a barrier to the adoption of wind. The reason is the higher capital intensity of the affected renewable technologies in comparison with conventional ones. As shown in Sections 5 and 6 , this conclusion is robust under different assumptions about the bases ised to calculate property taxes.

Taxes on inputs are incentives for the hydro and solar technologies adopted by NUGs, but they are neither incentives nor barriers for adoption by IOUs. Similarly, state income taxes are an incentive for biomass-plantation and wind technologies if adopted by NUGs, but are neither barriers nor incentives if adopted by IOUs.

Holding effects of the AMT aside for the moment, certain provisions of federal income tax laws provide more incentives for adopting renewable technologies than conventional ones by both IOUs and NUGs. First, as indicated by the analysis in Sections 5 and 6 , although accelerated depreciation benefits all renewable and conventional technologies, it is more of an incentive for many of the renewable technologies. This is especially true because of the very short tax depreciation lives of solar, wind, hydro, and geothermal technologies adopted by IOUs and solar, wind, geothermal, and biomass plants adopted by NUGs. Second, provisions of EPACT extending the investment tax credit for solar and geothermal technologies that are adopted by NUGs and providing a $1.5 \mathrm{c} / \mathrm{kWh}$ production incentive credit for dedicatedplantation biomass and wind technologies adopted by both IOUs and NUGs are especially attractive financial incentives for the affected ownership types.

\footnotetext{
${ }^{3}$ Because the financial indicator for NUGs is expressed as a percentage, an alternative method was also used to calculate relative barriers and incentives for NUGs. The alternative is based on differences in percentages--rather than differences in ratios. The results of using this alternative method do riot change conclusions substantially on barriers and incentives. These results are contained in Table C.4 of Appendix C.
} 
If a NUG is subject to the AMT, however, the NUG is not able to take advantage of the federal tax incentives for renewables and, therefore, the federal tax laws become a barrier to the adoption of renewable technologies compared with conventional ones. Dedicated-plantation biomass and wind technologies are especially harmed by the AMT because the $1.5 \mathrm{c} / \mathrm{kWh}$ credit cannot be used.

As Table 7.1 indicates, of the ratemaking procedures that we modeled, the only one that provides a barrier or incentive to the adoption of renewable technologies is tax normalization. It is an incentive for the adoption of hydro, solar, and wind technologies.

If we were able to quantify the effects of the ratemaking procedure that passes the risk of fuel-price fluctuations to ratepayers, the results would show that this procedure is a barrier to the adoption of renewable technologies that are not subject to fuel-price fluctuations. 


\section{REFERENCES}

Alliance to Save Energy, 1993, Federal Energy Subsidies: Energy, Environmental, and Fiscal Impacts, Washington, DC, April.

American Solar Energy Society (ASES), 1992, Economics of Solar Energy Technologies, eds. R. Larson, F. Vignola, and R. West, Boulder, December.

Commerce Clearing House, Inc., 1993, 1993 U.S. Master Tax Guide, Chicago, Illinois.

Commerce Clearing House, Inc., 1993, 1993 Depreciation Guide, Report 29, Volume 80, Chicago, Illinois.

DeLaquil, P., D. Kearney, M. Geyer, and R. Diver, 1993, "Solar Thermal Electric Technology," in Renewable Energy: Sources for Fuel and Electricity, eds. T. Johansson, H. Kelly, A. Reddy, and R. Williams, Island Press, Washington.

Edison Electric Institute, 1992a, Statistical Yearbook of the Electric Utility Industry 1991, Washington, DC, October.

Edison Electric Institute, 1992b, State Regulation of Non-Utility Generation, Washington, DC, 2 Volumes, March.

Electric Power Research Institute, 1989, Technical Assessment Guide: Electricity Supply, Vol. 1, Rev. 6, Palo Alto, California, December.

Electric Power Research Institute (EPRI), 1992, Biomass State-of-the-Art Assessment, GS7471, Prepared by Research Triangle Institute, April.

Energy Information Administration, 1992, Federal Energy Subsidies: Direct and Indirect Interventions in Energy Markets, Washington, DC, SR/EMEU/92-02, November.

Energy Information Administration, 1993a, Assumptions for the Annual Energy Outlook 1993, Washington, DC, DOE/EIA-0527(93), January.

Energy Information Administration, 1993b, Annual Energy Outlook 1993, Washington, DC, DOE/EIA-0383(93), January.

Energy Information Administration, 1993c, The Changing Structure of the Electric Power Industry, Washington, DC, DOE/EIA-0562, March.

Hamrin, J. and N. Rader, Investing in the Future: A Regulator's Guide to Renewables, National Association of Regulatory Utility commissioners, Washington, February 1993.

Hill, Lawrence J., 1988, Pisblic Power in the U. S. Electric Utility Industry: Regulatory Issues and Comparative Finan $r^{\circ}$ I Indicators across Ownership Types, Oak Ridge National Laboratory, Oak Ridge, Tennessee, ORNLTM-10497, January. 
Hill, Lawrence J., Moshe Golstein, R.G. Alsmiller, and Brian Toney, 1982, An Evaluation of the National Utility Financial Statement (NUFS) Model, U.S. Departmont of Energy, Energy Information Administration, DOE/EIA-0373, December.

Hill, Lawrence J., Eric Hirst, and Martin Schweitzer, 1991, Integrating Demand-Side Management Programs into the Resource Plans of U.S. Electric Utilities, Oak Ridge National Laboratory, Oak Ridge, Tennessee, ORNL/CON-311, January (also published by the Electric Power Research Institute, Palo Alto, California, EPRI TR-100255, December 1991).

National Association of Regulatory Commissioners, 1992, Utility Regulatory Policy in the United States and Canada, Washington, DC.

National Renewable Energy Laboratory (NREL), 1990, The Potential of Reriewable Energy: An Interlaboratory White Paper, Prepared by Idaho National Engineering Laboratory, Los Alamos National Laboratory, National Renewable Energy Laboratory, Oak Ridge National Laboratory, and Sandia National Laboratories, published by NREL, SERI/TP-260-3674, Golden, Colorado, MArch.

Oak Ridge National Laboratory and Resources for the Future, 1992, U.S.-EC Fuel Cycle Study: Background Document to the Approaches and Issues, Oak Ridge National Laboratory, Oak Ridge, Tennessee, ORNL/M-2500, November.

Palmerini, C. G., 1993, "Geothermal Energy," in Renewable Energy: Sources for Fuel and Electricity, eds. T. Johansson, H. Kelly, A. Reddy, and R. Williams, Island Press, Washington.

Schweitzer, Martin, Eric Hirst, and Lawrence J. Hill, 1991, Integrated Resource Plans and Processes: Findings from a Survey of 24 Electric Utilities, Oak Ridge National Laboratory, Oak Ridge, Tennessee ORNL/CON-314, February.

U.S. Advisory Commission on Intergovernmental Relations, 1992, Significant Features of Fiscal Federalism, Volume 1: Budget Processes and Tax Systems, Washington, DC, PB-92198860 , February.

U.S. Department of Energy, 1991/1992, Integrated Analysis Supporting the National Energy Strategy: Methodology, Assumptions, and Results, Technical Annex 2, Washington, DC.

U.S. Department of Energy (USDOE), 1992, Electricity from Biomass: A Development Strategy, Office of Solar Energy Conversion, Washington, DOE/CH10093-152, April.

U.S. General Accounting Office, 1993, Electricity Supply: Efforts Under Way to Develop Solar and Wind Energy, Washington, DC, GAO/RCED-93-118, April. 
APPENDIX A: DESCRIPTION OF THE MODEL

A-1 


\section{A.1. BACKGROUND}

In this appendix, we discuss technical features of the financial regulatory model used in this study. The specification of the model is an extension of one provided the authors by Dona Burney of the District of Columbia Public Service Commission. Because the changes are substantial, however, the authors accept full responsibility for the current specification.

As discussed in the text, financial simulations were executed for the decisionmaking criteria of both IOUs and NUGs. Therefore, the discussion in this appendix is divided into two parts, addressing, first, electric utilities and then NUGs. Because many financial issues pertaining to NUGs are similar to or the same as those of lOUs, the discussion of NUGs will be abbreviated.

The computer model used to analyze the various tax and ratemaking procedures is based on a spreadsheet that calculates the contribution of a single power plant to a utility's financial performance. It includes such factors as the capital outlays, debt requirements, fuel costs, O\&M costs, depreciation, taxes, rate base, and return to equity holders. The model develops full financial statements for the plant for each year from the beginning of construction to final shutdown. A variation of the model uses a fixed input price instead of a rate base calculation for pricing in order to model an NUG.

Because the model considers only the construction of a single plant, it does not have to deal with issues such as demand growth, retirement of existing capacity, and the type of plant needed. We assumed for the purpose of this study that the utility had decided that the technology being modeled matched its needs in the way of capacity and timing. Generation is based solely on the input capacity times the input capacity factor. This reduces the complexity of the analysis to allow us to focus on the tax and ratemaking procedures as they affect each technology.

The costs of a single plant affect the parent utility through increases or decreases in the balance sheet and earnings statement. This will affect the taxes to be paid, the rate base on which the utility can collect, and the consequent cash flow. This study look at the effects of a technology at the margin for a utility and does not look at a hypothetical utility in its entirety.

\section{A.2. INVESTOR-OWNED ELECTRIC UTILTTIES (IOUS)}

\section{A.2.1. Overview}

In Fig. A.1, we summarize how the financial regulatory model calculates required revenues for IOUs. The levelized cost is simply the discounted value of the required revenues by the annual electricity generation. 


\section{FIGURE A.1 \\ RATEMAKING FORMULA FOR INVESTOR-OWNED UTILITIES}

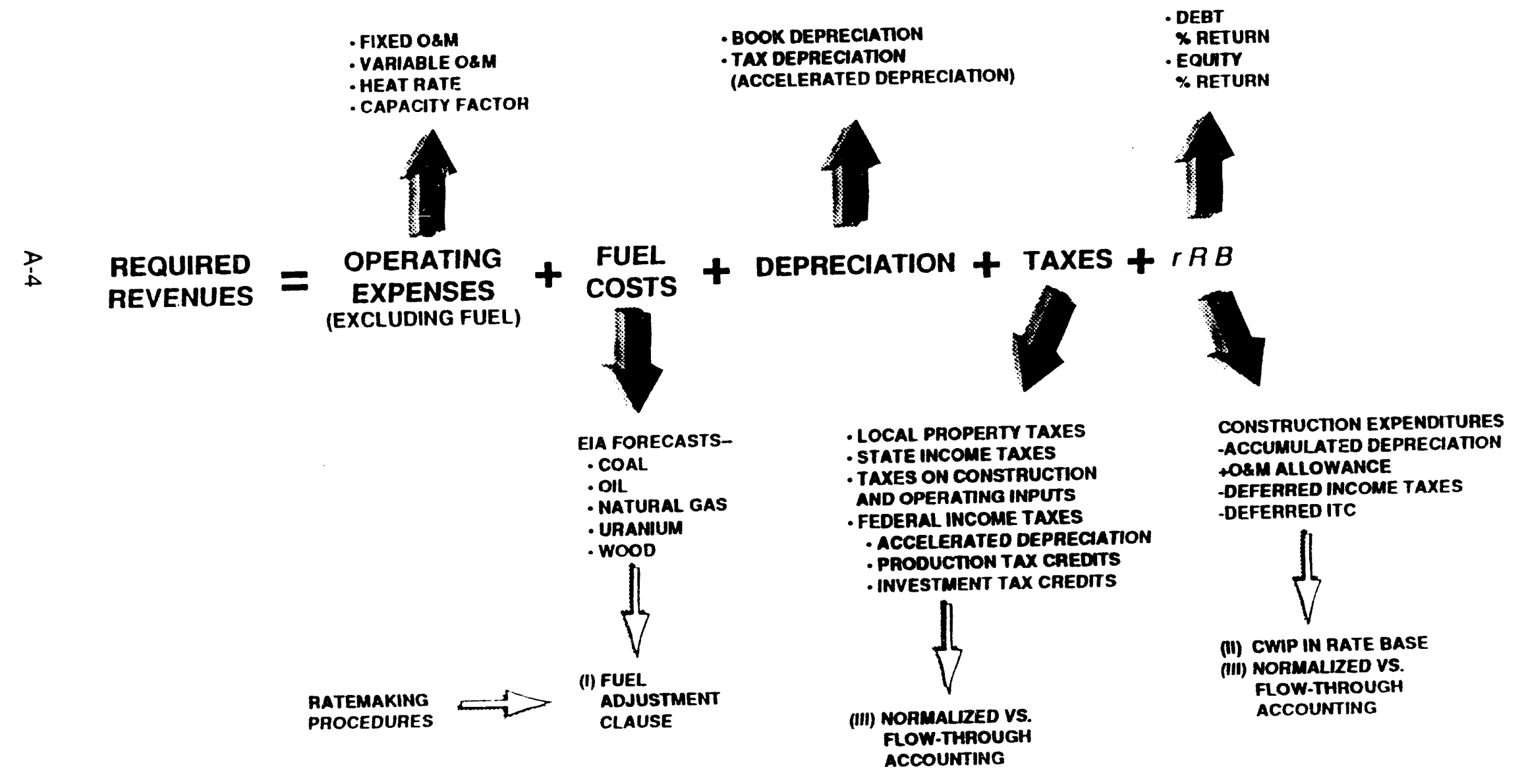




\section{A.2.2. Components of Required Revenues}

\section{A.2.2.1. Fuel Costs}

The 1991 cost of fossil fuels and their projected values over the useful lives of the plants considered in the study (in 1991 dollars) were obtained from the Energy information Administration.

Fuel costs are calculated on the basis of plant production and capacity and escalated if necessary. Because taxes on fuel are calculated later in the model, the input fuel cost is multiplied by the input percentage of the fuel cost not attributed to sales tax. The equation is

Fuel Cost per kWh = Input Fuel Cost per kWh $\times$ Fuel Cost \% without Tax.

This fuel cost is then converted to thousands of dollars by multiplying by the production rate for each year and escalated based on the basis of the input escalation rate:

Fuel Cost $=$ Fuel Cost $\$$ per MWh $\times$ Capacity $\times$ Capacity Factor $\times 8760$ hours $\times$ $(1+\text { Fuel Escalation })^{t-10} \times(K \$ / 1000 \$)$

where $t=$ year of outlay and to $=$ first year.

To model the lack of an automatic fuel adjustment clause (one of the sensitivities studied), the fuel costs in the required revenue calculation increase at only the O\&M escalation rate (our stand-in for the general inflation rate) instead of the fuel escalation rate for the next year. If the fuel escalation rate is higher, then not all fuel costs are recovered that year. The shortfall is then recovered the following year. However, that next year has a similar shortfall for its year's fuel cost based on the differential escalation rates. The equation is:

Fuel Cost Recovered $=$ [Fuel Cost $x(1+$ O\&M Escalation $) /(1+$ Fuel Escalation $)]$ + (Fuel Cost using fuel escalation ${ }_{t-1}-$ Fuel Cost using O\&M escalation t $_{t-1}$ )

The result is that the revenue in the first year of plant operation has a fairly significant shortfall based on the difference in escalation rates, and the revenue for all future years have a very minor difference because they inciude the previous year's shortfall. Finally, in the year after shutdown, the missing fuel costs are recovered.

\section{A.2.2.2. Other O\&M Expenses}

O\&M expenses other than fuel include labor and materials used in operation, plant maintenance, waste disposal, and site management. For some technologies, such as geothermal and nuclear, these costs are a significant fraction of the overall costs. The costs may be entered into the model as a fixed cost per kilowatt of capacity or as a cost per kilowatt-hour produced. The costs are split between labor, material, and taxes on 
labor and material. The user inputs the appropriate percentages of the total that represent the labor and material costs without taxes. Later in the model, these costs will be multiplied by the appropriate input tax rate to find the tax components of the O\&M costs. The equations are

O\&M Labor Cost $=$ Input O\&M Cost $x$ Labor Cost $\%$ without Tax

O\&M Material Cost = Input O\&M Cost $\times$ Material Cost $\%$ without Tax.

These are converted to thousands of dollars and escalated using the input O\&M escalation rate:

$$
\begin{aligned}
\text { O\&M Cost }= & {[O \& M \$ \text { per MWh } \times \text { Capacity } \times \text { Capacity Factor } \times 8760 \text { hours }} \\
& + \text { O\&M } \$ \text { per } k W \times \text { Capacity } \times(1000 \mathrm{~kW} / \mathrm{MW})] \\
& \times(1+\text { Fuel Escalation })^{t-10} \times(\mathrm{K} \$ 1000 \$) .
\end{aligned}
$$

\section{A.2.2.3. Depreciation}

Before depreciation is calculated, the total capital cost of the plant must be found. The input contains the total capital cost of the plant in dollars per kilowatt. This cost is the overnight construction cost. In other words, it is the cost in constant dollars without interest or inflation due to the length of time it takes to build the plant. These two factors are calculated separately within the model. The input includes a schedule showing what fraction of the plant is built in which year before the plant comes on-line. These fractions are based on constant dollars and total to $100 \%$. The capital outlays in a given year are equal to the total capital cost times the fraction of total cost for the appropriate year before start-up times the escalation factor for construction costs.

$$
\begin{aligned}
\text { Capital Outlay }_{t}= & \text { Capital Cost } \times \text { Fraction of Total } \\
& \times(1+\text { Construction Escalation Rate })^{t-10}
\end{aligned}
$$

where ts = year of startup.

The input to the model also includes the percentages of the capital cost that are attributable to labor, material, energy, and land. These percentages do not include the taxes on each of these components; the taxes on these inputs are calculated separately. The capital outlay is multiplied by each one of the components' fractions to find their representative cost. The cost for each is then multiplied by the appropriate tax rate to find the taxes on that input to the capital cost. The sum of all components and their taxes total to $100 \%$ of the capital outlay for the year:

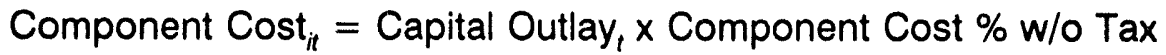

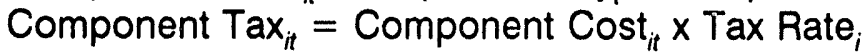

$$
\Sigma_{i} \text { Component } \text { Cost }_{i t}+\text { Component } \operatorname{Tax}_{i t}=100 \% \text { of Capital Outlay, }
$$

where $\mathbf{i}=$ Cost Category (Labor, Energy, Material, Land). 
As capital outlays are made, they are added into an asset account called Construction Work in Progress (CWIP). In the year the plant begins operation, the cost is transferred to Gross Plant \& Equipment (Gross P\&E). Except for the cost of the land, these costs are depreciated as described below. The land value, on the other hand, is held on the books at cost. In the last year of operation, the land is simulated to be sold at cost. Since revenue and cost offset each other, this transaction has no effect on the required revenue calculation or the income statement. The sale of the land does, however, increase equity cash flow in the final year. This land value can be thought of as the salvage value of the facility at the end of its life.

A separate asset which must be depreciated, if it exists, is the Allowance for Funds used During Construction (AFUDC). It represents the amount of return that the utility would have earned on the CWIP if it had charged customers the allowed rate of return on assets before operation. The AFUDC accumulates during the construction phase and enters the ratebase when the plant begins operation. It then is depreciated over the life of the plant using straight line depreciation just as the rest of the P\&E (see below). The model separates the components of AFUDC between allowance for borrowed funds (AFBF) and equity funds (AFEF). The equations are

$$
\begin{aligned}
& A F B F=(C W I P+\text { cumulative AFUDC })_{B O Y} \times \text { Debt Ratio } \times \text { Interest Rate } \\
& A F E F=(\text { CWIP }+ \text { cumulative AFUDC })_{B O Y} \times(1-\text { Debt Ratio }) \times \text { Allowed Return on } \\
& \text { Equity }
\end{aligned}
$$

Annual AFUDC $=A F B F+A F E F$,

where $\mathrm{BOY}=$ Beginning of year.

The AFUDC enters the income statement as a quasi-revenue but is not a real cash inflow. Instead, it is collected from customers over the life of the plant through its depreciation and the earned return on the undepreciated portion. If the user chooses to allow CWIP in the ratebase, AFUDC does not exist because the utility is truly recovering the funds during construction.

Book depreciation is now calculated so that it may be collected in the required revenue. As mentioned above, this includes all the capitalized costs except land, i.e., labor, material, energy, and taxes on the four components. In addition, the AFUDC is depreciated over the life of the plant and collected in revenues. Land)

Annual Book Depreciation $=($ Gross Plant \& Equipment (including AFUDC) -

$$
\text { / Plant Life }
$$

Tax depreciation is calculated using a double-declining balance method if the tax life is less than 15 years and a one-and-a-half declining balance for tax lives of 15 years or greater. Tax calculations do not include AFUDC. The equation is 


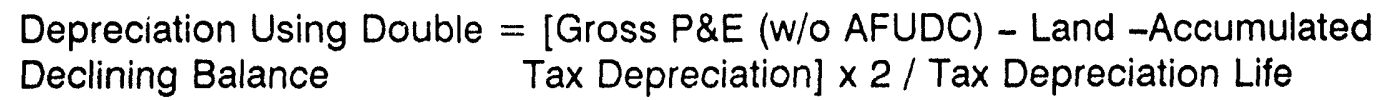

Note: One-and-a-half declining balance would use 1.5 instead of 2 in the equation.

The tax code requires that the calculation assume that the plant starts in the middle of the first year of operation for tax depreciation. For example, a plant with a 5year tax life would have depreciation of $20 \%$ of its value in the first year. In the secc nd year, the amount would be $32 \%(40 \%$ of the remaining $80 \%$.) The third year would be $19.2 \%$ ( $40 \%$ of the remaining $48 \%$.)

Because the double-declining balance equation never fully depreciates an asset, the amount of depreciation using straight line depreciation is also calculated. This straight-line calculation, however, only uses the net value of the plant and the years remaining in the tax life of the plant. Towards the end of the tax life, the straight-line value is higher than the double declining balance value. Once it becomes higher, this straightline depreciation is used instead.

Annual Tax Depreciation = MAXIMUM [Double-Declining-Balance method, (Gross P\&E (w/o AFUDC) - Land - Accumulated Tax Depreciation)/ Years Remaining in Tax Life].

To continue the example, in the fourth year the double-declining balance method sets the depreciation at $11.52 \%$. The straight-line depreciation of the remaining $28.8 \%$ of the asset over two and a half years is also $11.52 \%$. In the fifth year the double-declining balance equation gives only $6.9 \%$; the straight-line value of $11.52 \%$ is used again. In year 6 , the final $5.76 \%$ is depreciated.

\section{A.2.2.4. Taxes}

There are a variety of taxes included in the model. All taxes are included in the required revenue calculation at some point in time. Expensed taxes are those that are not capitalized in the plant. They are recovered in the year of their expense. Capitalized taxes are those that were part of the construction costs and are built into the capital costs. They are expensed as part of the depreciation cost of the plant. Property taxes are paid on the basis of assessed values and an input rate. The income tax calculation includes both the current taxes payable and the annual deferred taxes that are due to accelerated depreciation. Any available tax credits reduce the current taxes and consequently lower the required revenues.

Taxes on the inputs to production are charged on the fuel, labor, materials, and land costs for each year. These are found by multiplying the appropriate cost category by the input tax rate:

Input Taxes on Costs $_{i t}=$ Cost $_{i t} \times$ Tax Rate $_{i}$,

where $\mathrm{i}=$ Cost Category (Labor, Eneryy, Material, Land), and $\mathrm{t}=$ year. 
Those taxes on cost components of the capital outlays for the plant are incorporated into the CWIP and thence into the P\&E. The taxes are then depreciated over time along with the rest of the plant. Taxes on the inputs to production that are expensed in the same year (i.e., O\&M labor, O\&M materials, fuel) appear on the income statement and in the revenue requirement calculation in the same year as the expense.

The model has the capability to calculate a tax on the kilowatt-hour output of the plant. This was used in early versions of the model to analyze the proposed BTU tax, but was not used in the results of the final report.

Property taxes are calculated by multiplying the assessed value of the plant by the input tax rate. There are several methods within the model for simulating the assessed value. The net book value is used in the reference scenarios in the absence of a known market value. The input tax rate should be adjusted beforehand to take into account that many states assess property at a fraction of its full value.

Property Tax $=$ Assessed Value $\times$ Property Tax Rate,

where Assessed Value $=$ Net Book Value of Plant, or

Gross Book Value of Plant, or

Net Present Value of remaining Cash Flow to Equity, or

Net Book Value of Plant less Land Value.

The model calculates income taxes by developing an income statement that uses accelerated depreciation instead of book depreciation and does not include any allowance for funds used during construction. Pre-tax income is calculated by subtracting fuel, O\&M, accelerated depreciation, and interest from the required revenue amount.

$$
\begin{aligned}
& \text { Pre-Tax Income }=\text { Revenue }- \text { Fuel }- \text { O\&M Cost - Accelerated Depreciation } \\
& \text { - Interest }
\end{aligned}
$$

From this amount is subtracted the expensed taxes on inputs, property taxes, and production taxes. This amount is multiplied by the state income tax rate to determine the state income taxes. The equation is

$$
\begin{aligned}
\text { Current State Income Taxes } & =(\text { Pre-Tax Income }- \text { Input Taxes }- \text { Property Taxes } \\
& - \text { Production Taxes }) \times \text { State Income Tax Rate }
\end{aligned}
$$

The current federal income taxes payable are found similarly, but since state taxes are tax-deductible, state income taxes are included in the equation.

$$
\begin{array}{r}
\text { Current Federal Income Taxes = } \\
\text { (Pre-Tax Income - Input Taxes - Property } \\
\text { Taxes - Production Taxes - Current State } \\
\text { Income Taxes }) \times \text { Federal Income Tax Rate }
\end{array}
$$

Because the required revenue calculation includes the income taxes, which in turn require the revenue amount, iteration would normally be required. However, the equations 
for the income taxes can be reformulated to eliminate the recursiveness. Doing this greatly speeds the calculation.

Annual deferred taxes are those taxes which will eventually be paid but are not due yet because of accelerated depreciation. They are found by taking the difference between the two forms of depreciation and multiplying by the state and federal income tax rate. Since tax calculations do not use AFUDC, the book depreciation has this component removed. The equation is

\section{Annual Deferred Taxes $=($ Tax Depreciation - Book Depreciation (w/o AFUDC) $)$ $x$ (State Income Tax Rate + Federal Income Tax Rate).}

In the early years, deferred taxes will be positive because of the high accelerated depreciation. Once the plant is past its tax life, the annual deferred taxes will be negative. The deferred taxes are accumulated and treated as a liability on the balance sheet because they must eventually be paid. As they are paid (negative annual deferred taxes) the cumulative amount declines to zero at the end of the book life of the plant.

If taxes are normalized, the deferred taxes are collected from ratepayers in the revenue calculation. This raises the revenue requirement in the early years and lowers it in the later years. However, the accumulated deferred taxes are subtracted from the asset value in the rate base calculation. Customers should not have to pay the taxes early (by paying deferred taxes) as well as pay a return to the utility on those funds until they are paid to the government. If taxes are not normalized, then the revenue calculation would include only current taxes and not deferred taxes.

The investment tax credit is found by multiplying the gross P\&E by the input tax credit rate. It applies only in the first year of operation.

Investment Tax Credit $=$ Gross P\&E (w/O AFUDC) $\times$ ITC Rate.

The production tax credit calculation is more complicated. The EPACT establishes a $1.5 \% / \mathrm{kWh}$ tax credit for wind and closed-loop biomass projects. However, it applies in full only if the price of electricity from the plant is at or below $8 \Phi / \mathrm{kWh}$. Between 86 and 116 , the credit decreases linearly to zero. At prices over $116 / \mathrm{kWh}$, no credit applies. The equation used is

$$
\begin{gathered}
\text { Production Tax Credit }=1.5 \varnothing / \mathrm{kWh} \times \text { MINIMUM[1.0, MAXIMUM((11థ/kWh-Price }) \\
/ 3,0.0)] \times \text { Production }
\end{gathered}
$$

A price is not specifically used for sales of electricity from the plant if it is modeled as utility-owned. Instead, an effective price is calculated by dividing the calculated required revenue by the production amount. Since the effective price requires the required revenue which requires the credit amount, a recursive formula and iteration must be used.

Also, the credit is available only during the first 10 years of plant operation. Inflation factors can be applied to the 1.54 and 84 figures. 
Because the investment and production tax credits are not taxable, their impact is amplified. For example, the production tax credit lowers required revenues by $1.56 / \mathrm{kWh}$. Lowered revenues lower the federal income taxes by $35 \%$ of the credit; this decrease, in turn, lowers required revenues further. The result is that the effective price is lowered $2.27 \% / \mathrm{kWh}$, an amplification of over $50 \%$. A similar effect occurs with state income taxes.

\section{A.2.2.5. Return on Rate Base}

The return on rate base is equal to the rate base at the beginning of the year multiplied by an allowable percentage return based on the cost of capital. The rate base equation is

$$
\begin{aligned}
\text { Total Rate Base }= & \text { Net } \\
& + \text { CaE }+ \text { CWIP Allowed in Rate Base } \\
& \text { - Capitalized AFUDC + Working Capital } \\
&
\end{aligned}
$$

The working capital is defined as an input fraction of the next year's O\&M cost (we used $12.5 \%$ ). This is used to represent that the utility needs about 1.5 months of the operating costs in reserves. The other components of the rate base were discussed in previous sections.

In the years before operation, the only non-zero component of the rate base is the CWIP allowed. If no CWIP is allowed, the rate base is zero until the plant comes on-line. Except under this circumstance, the rate base is also equal to the sum of the debt and equity investment. It is not equal to total assets because the deferred taxes liability does not earn a return, since the customers have already paid this through normalization of taxes.

The allowable percentage return on investment is the weighted average cost of debt and equity capital before taxes. Since deferred taxes, which earn no return, are subtracted out of the rate base, the percentage return must be modified to reflect this. Therefore, the total return on rate base is equal to

$$
\begin{aligned}
\text { Allowed \% Return }= & \text { Allowed Equity Rate of Return } \times\left(\text { Equity }_{\text {8or }} / \text { Rate Base }\right) \\
& + \text { Interest Rate } \times\left(\mathrm{Debt}_{\mathrm{Bor}} / \text { Rate Base }\right)
\end{aligned}
$$

This equation does not use after-tax cost of capital because it is used to calculate total revenues before taxes. The return on rate base is then equal to the total rate base times the allowed return. It also equals the iriterest charge for the year plus the equity investment times its allowed rate of return. The equations are

Return on Rate Base $=$ Total Rate Base $\times$ Allowed \% Return, or

Return on Rate Base $=$ Interest Charge + Allowed Return on Equity.

New debt is issued each year on the basis of multiplying the sum of capital 
outlays, AFUDC, and working capital requirements by the input debt ratio:

Debt Issued $_{t}=\left(\right.$ Capital Outlays $_{t}+$ AFUDC $_{t}+$ Change in Working Capital $\left._{t}\right)$.

Interest is charged on the amount of debt held at the beginning of the year. (To ease calculations throughout the modeling, we assumed that all transactions are carried out at year-end and that the plant begins operation at the beginning of a year.)

Debt is retired at the same rate that the capital investment is depreciated using book depreciation. Although this may not be the same schedule that actual utiiities use, it maintains a constant debt ratio over the life of the investment and avoids perturbations based on bond lengths versus plant lives. Since this model simulates only one power plant instead of the utility's entire asset base, this assumption is a reasonable simplification.

\section{A.2.3. Decisionmaking Criteria}

Marginal income statements and balance sheets reflecting the financial effects of each of the technologies are calculated for each year. These can be used to calculate financial ratios familiar to investment analysts. The results are also important for use in the calculation of the next year's costs and revenue requirements.

\section{A.2.3.1. Levelized Cost}

The levelized cost to customers equals the net present value (NPV) of the annual revenue from electricity sales as calculated using the rate base formula divided by the NPV of the kilowatt-hours produced. (Our model considers only busbar costs and does not include transmission losses of electricity.) The net present value of the revenue required is the sum of the revenues over the life of the plant, with each year's revenues discounted by the cost of capital to the present.

$$
\operatorname{NPV}(\text { Revenues })=\Sigma, \text { Revenues, } \times(1+\text { discount rate })^{t-10}
$$

where Revenues $=$ calculated revenues required from rate base calculation .

The equation uses the weighted average cost of capital to the utility after taxes for the discount rate. It is based on the allowed return on equity and the after-tax cost of debt, weighted by the percentage of each form of investment used during construction.

Cost of Capital $=$ Allowed Equity Rate of Return $\times(1-$ Debt Ratio $)+$ Interest

Rate $\times$ Debt Ratio x (1 - Federal Income Tax Rate - State Income Tax Rate + Federal Income Tax Rate + State Income Tax Rate).

In scenarios with no income tax, the equation uses the reference scenario tax rates to provide a more consistent comparison.

The NPV of kilowatt-hours produced is used to find the levelized price through the 
following equations. We want to find a single price which, when multiplied by the kilowatthours produced each year, gives the same NPV of revenues as the actual stream of revenues.

$$
\text { NPV (Revenues) }=\text { NPV (Levelized Price } \times \mathrm{kWh} \text { produced). }
$$

Since the levelized price is a constant, it can be pulled out of the NPV equation:

$$
\text { NPV (Revenues) }=\text { Levelized Price } \times \text { NPV }(\mathrm{kWh} \text { produced). }
$$

The levelized price can then be found by rearranging the equation:

Levelized Price $=$ NPV $($ Revenues $) /$ NPV $(\mathrm{kWh}$ produced).

The levelized price can also be thought of as the levelized cost to customers. In this study we use the terms interchangeably.

The revenue can be segmented on the basis of the various types of costs used to calculate it. We have combined these into seven major groupings for the tables in Appendix B. These are: capital costs, O\&M costs, fuel costs, federal taxes, state and local taxes, property taxes, and tax credits.

\section{A.2.3.2. Internal Rate of Return}

The cash flow to the debt and equity holders combined is the basis for calculating the internal rate of return. This defines the cash flow of the project as a whole, without regard to the financial arrangements in its financing. It can be found through components of the income statement and balance sheet or through a bottoms-up summation of cash inflows and outflows.

or

Cash Flow $=$ Cash Revenues - Capital Outlays - Fuel Costs - O\&M Costs Change in Working Capital - Taxes,

Cash Flow $=$ Net Income + Depreciation + AFUDC Depreciation + Deferred Taxes + Interest - Capital Outlays -AFUDC.

The internal rate of return (IRR) is the discount rate that causes the NPV of the net cash flow over the entire period to equal zero. Using the earlier NPV equation but with cash flow:

$$
N P V(\text { Cash Flow })=\Sigma, \text { Cash Flow } x(1+\operatorname{RRR})^{1-10}=0.0
$$

The value is found through iteration and is built into the spreadsheet software.

\section{A.2.3.3. Internal Rate of Return - Equity}

Equity cash flow is the basis for calculating the internal rate of return to equity 
holders. It can be calculated either through use of the income statement and adjustments based on noncash expenses and revenues, or through a bottoms-up summation of cash inflows and outflows.

$$
\begin{aligned}
\text { Equity Cash Flow }= & \text { Cash Revenues }+ \text { Debt Issued }- \text { Capital Outlays }- \text { Fuel } \\
& \text { Costs }- \text { O\&M Costs }- \text { Change in Working Capital }- \text { Interest } \\
& \text { Payment }- \text { Debt Retirement -Taxes }
\end{aligned}
$$

or

$$
\begin{aligned}
\text { Equity Cash Flow }= & \text { Net Income }+ \text { Depreciation }+ \text { AFUDC Depreciation }+ \\
& \text { Deferred Taxes }+ \text { Debt Issued }- \text { Capital Outlays }- \text { Debt } \\
& \text { Retired }- \text { AFUDC. }
\end{aligned}
$$

Equity cash flow represents the funds either received from or paid out to the parent utility. The funds may be from internally generated sources within the utility or from stock issues. Funds out may be paid to stockholders as dividends or used to fund other projects of the utility. The original source or ultimate use of the equity funds outside this model are not important to this study.

The Internal Rate of Return - Equity (IRR-Equity) uses the same NPV equation as the IRR but uses the equity cashflow instead of the project cash flow.

\section{A.3. NONUTILTYY GENERATORS}

\section{A.3.1. Overview}

In Fig. A.2, we summarize how the financial regulatory model determines net income for a NUG. In contrast to IOUs (Fig. A.1) there are no ratemaking procedures for NUGs.

\section{A.3.2. Components of Net Income}

\section{A.3.2.1. Revenues}

Revenues for NUGs are a single input price multiplied by the electricity production to calculate revenues. This simulates a fixed price contract with a utility based on an agreed-upon price, such as avoided cost in the year of the contract. Since these cases used real rates of return with no escalation for inflation, this is equivalent to having a price set at the beginning of plant operation but escalating with general inflation. In reality, NUG contracts are much more complex, involving many more variables in prices, terms, conditions, and time periods; but analysis of the consequences of such variables is beyond the scope of this study.

\section{A.3.2.2. Fuel Costs}

See the discussion in Sect. A.2.2.1. 
FIGURE A.2

\section{NET INCOME FOR NON-UTILITY GENERATORS}

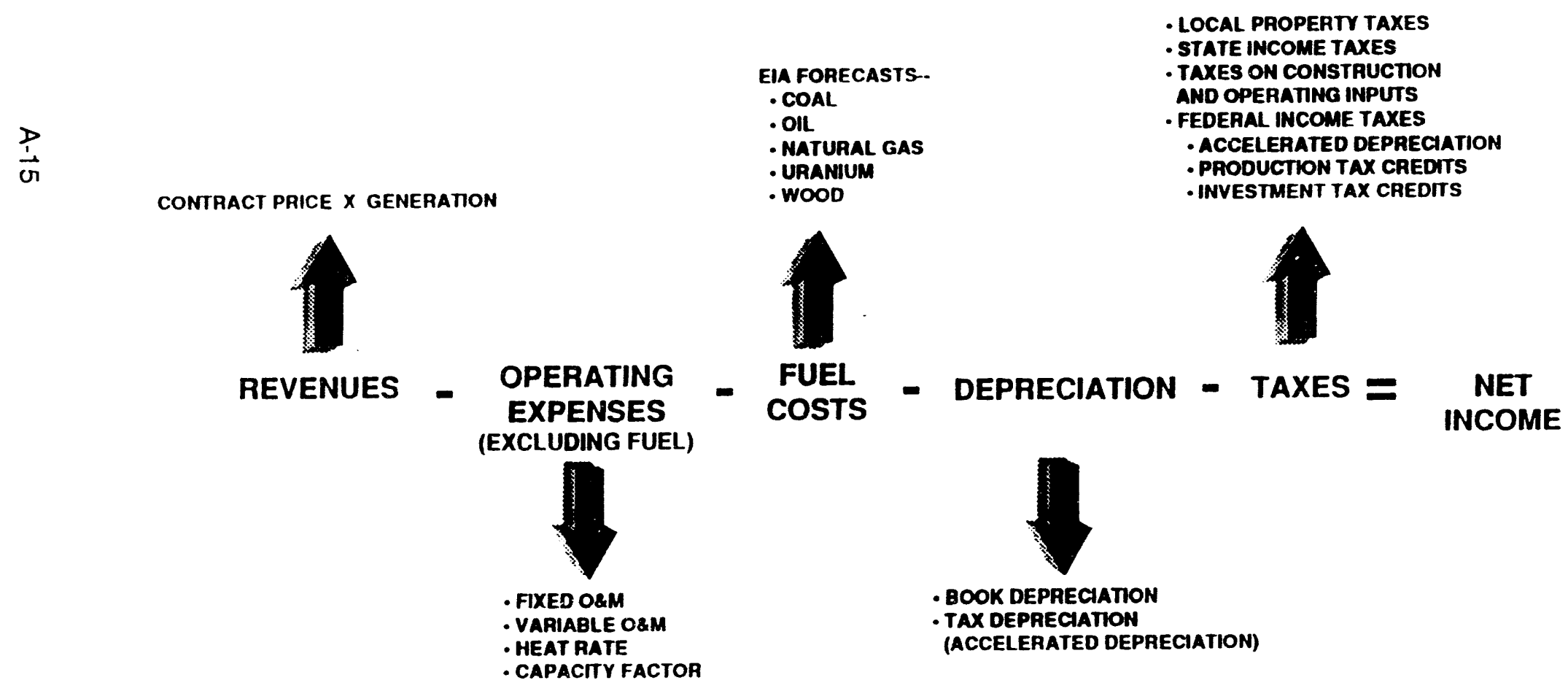




\section{A.3.2.3. Other O\&M Expenses}

See the discussion in Sect. A.2.2.2.

\section{A.3.2.4. Depreciation}

See the discussion in Sect. A.2.2.3.

\section{A.2.2.4. Taxes}

Taxes are calculated the same for NUGs as for IOUs (Sect. A.2.2.4) except that we include two options. The first option is that the AMT applies to the NUG. The second option is that operating losses have to be carried forward rather than causing income taxes to be negative.

The AMT applies if a corporation relies too much on tax benefits such as accelerated depreciation to lower its tax bill. The AMT reduces those tax advantages but uses a lower tax rate in calculating the alternative tax. The model calculates tax depreciation using the longer depreciation life specified in the tax code. It then determines an AMT Income based on normal revenues, expenses, and this new depreciation amount. It multiplies the AMT Income by $20 \%$ to find the AMT. If this amount is higher than the regular tax that would have been paid (or a smaller tax credit for operating losses), the AMT is used instead of the regular tax.

\section{Alternative Minimum Tax $=$ (Revenues - Alternative Depreciation -Other Expenses) $\times 20 \%$
Current Taxes Payable $=$ Maximum (Regular Current Taxes, Alternative Minimum Tax)

Carryforward of operating losses is required if the NUG does not have sufficient offsetting positive taxes elsewhere in its operations to use these operating losses. In this case, it must carry the losses forward until they can be used to offset positive taxes (see Sect. 4).

For example, in year $\mathrm{t}$, suppose net income before income taxes is $-\$ 100 \mathrm{~K}$. State and federal income taxes would be $-\$ 6 \mathrm{~K}$ and $-\$ 33 \mathrm{~K}$ respectively. Because taxes could not be negative, the $-\$ 39 \mathrm{~K}$ would be carried forward to arply against any positive taxes in the next year. In year $\mathrm{t}+1$, net income before income taxes is again $-\$ 100 \mathrm{~K}$. The resultant $-\$ 39 K$ in taxes would also be carried forward. In Year $t+2$, net income is $+\$ 60 \mathrm{~K}$. Taxes would be $\$ 23 \mathrm{~K}$. The model would use the carry forward from year $t$ to offset these positive taxes first. This would leave year $t$ carryforward at $-\$ 16 \mathrm{~K}$ and year $t+1$ at $-\$ 39 K$. If at the end of year $t+15$ any part of the remaining $-\$ 16 K$ had not been used to offset taxes, those credits would be lost to the corporation.

The net income before income taxes is based on using the accelerated depreciation of the project, as opposed to the book depreciation. This means that plants 
with high depreciation due to accelerated depreciation may show a profit on the regular income statement but have large losses on the tax income statement. These losses are what are carried forward in the tax calculation.

Although tax law allows a carryback and carryforward of losses, with carryback preferred, the model uses only carrytorward of losses. This is because losses generally occur at start-up before there are positive taxes to offset the losses. The credits are not carried on the balance sheet as receivables but only taken as extraordinary gains if used.

\section{A.3.3. Decisionmaking Criteria}

\section{A.3.3.1. Internal Rate of Return}

See Sect. A.2.3.2 for the discussion on IRR. For the NUG cases, the internal rate of return for combined Debt + Equity is used. This criterion helps show whether the project as a whoie has an adequate return, apart from the financing ratio of debt to equity. (However, the tax deductibility of interest does affect the overall return of the project.)

\section{A.3.3.2. Internal Rate of Return - Equity}

See Sect. A.2.3.3 for the discussion on IRR-Equity. This number represents the profitability of the project to the equity shareholders. Because of the amount of leverage involved (use of debt at a fixed interest rate), this criterion is similar to the IFR for the project but is very amplified. Increases in IRR of a few percentage points give increases in the IRR-Equity of tens of percentage points. Decreases in the IRR can make the IRREquity negative.

There is an additional complication in the IRR-Equity calculation. Because we modeled a generic debt repayment over the life of the plant without regard to funding availability, there are some cases where equity net cash flow becomes negative starting some years after the plant comes on-line. It may then turn positive again in the last years of operation as the interest payments and other costs decline relative to the fixed revenue stream. This causes an equity cash flow profile that is negative during construction, positive in the early years during accelerated depreciation, negative for some years, and maybe positive in the last few years. The IRR function may not give accurate results under these circumstances. It can actually give higher a IRR value with a lower net cash flow because a higher IRR reduces the weighting of the negative cash flow in the latter years. 
APPENDIX B: SIMULATION RESULTS

B-1 
Table B.1

Tax Simulation Results:

Levelized Cost and Internal Rate of Return, Investor-Owned Utilities

(Levelized Cost in e/kWh, IRR in \%)

\begin{tabular}{|c|c|c|c|c|c|c|}
\hline $\begin{array}{l}\text { GENERATING } \\
\text { ALTERNATIVE }\end{array}$ & $\begin{array}{l}\text { Reference } \\
\text { Base Tech } \\
\text { with Taxes } \\
\end{array}$ & $\begin{array}{l}\text { No Taxes } \\
\text { or Credits } \\
\end{array}$ & $\begin{array}{l}\text { No Prop- } \\
\text { erty Taxes }\end{array}$ & $\begin{array}{c}\text { No } \\
\text { Input Taxes } \\
\end{array}$ & $\begin{array}{c}\text { No State } \\
\text { Income Taxes }\end{array}$ & $\begin{array}{l}\text { No Credits } \\
\text { and No Fed. } \\
\text { Income Tax }\end{array}$ \\
\hline \multicolumn{7}{|l|}{$\begin{array}{l}\text { RENEWABLES } \\
\text { Biomass-Plantation }\end{array}$} \\
\hline Levelized Cost & 6.05 & 6.21 & 5.57 & 5.63 & 6.09 & 7.08 \\
\hline Int. Rate of Return & $5.91 \%$ & $6.00 \%$ & $5.91 \%$ & $5.91 \%$ & $5.92 \%$ & $5.99 \%$ \\
\hline Biomass-Waste & & & & & & \\
\hline Levelized Cost & 6.49 & 5.46 & 6.02 & 6.11 & 6.46 & 6.29 \\
\hline $\begin{array}{l}\text { Int. Rate of Return } \\
\text { Geothermal }\end{array}$ & $5.91 \%$ & $6.00 \%$ & $5.91 \%$ & $5.91 \%$ & $5.92 \%$ & $5.99 \%$ \\
\hline Levelized Cost & 6.16 & 5.29 & 5.53 & 5.75 & 6.19 & 6.30 \\
\hline $\begin{array}{l}\text { Int. Rate of Return } \\
\text { Hydro }\end{array}$ & $5.70 \%$ & $6.00 \%$ & $5.70 \%$ & $5.70 \%$ & $5.74 \%$ & $5.96 \%$ \\
\hline Levelized Cost & 2.90 & 2.07 & 2.34 & 2.71 & 2.88 & 2.79 \\
\hline $\begin{array}{l}\text { Int. Rate of Return } \\
\text { Solar-Photovoltaic }\end{array}$ & $5.85 \%$ & $6.00 \%$ & $5.85 \%$ & $5.85 \%$ & $5.87 \%$ & $5.98 \%$ \\
\hline Levelized Cost & 32.37 & 25.53 & 25.43 & 30.23 & 32.68 & 34.14 \\
\hline $\begin{array}{l}\text { Int. Rate of Return } \\
\text { Solar-Thermal }\end{array}$ & $5.65 \%$ & $6.00 \%$ & $5.65 \%$ & $5.66 \%$ & $5.70 \%$ & $5.96 \%$ \\
\hline Levelized Cost & 16.33 & 13.17 & 13.27 & 15.24 & 16.46 & 17.10 \\
\hline Wind Int. Rate of Return & $5.66 \%$ & $6.00 \%$ & $5.66 \%$ & $5.66 \%$ & $5.70 \%$ & $5.96 \%$ \\
\hline $\begin{array}{l}\text { Levelized Cost } \\
\text { Int. Rate of Return }\end{array}$ & $\begin{array}{l}3.30 \\
5.69 \%\end{array}$ & $\begin{array}{l}3.65 \\
6.00 \%\end{array}$ & $\begin{array}{c}2.52 \\
5.69 \%\end{array}$ & $\begin{array}{c}3.00 \\
5.69 \%\end{array}$ & $\begin{array}{c}3.40 \\
5.73 \%\end{array}$ & $\begin{array}{c}4.68 \\
5.96 \%\end{array}$ \\
\hline $\begin{array}{l}\text { CONVENTIONAL } \\
\text { Coal }\end{array}$ & & & & & & \\
\hline $\begin{array}{l}\text { Levelized Cost } \\
\text { Int. Rate of Return } \\
\text { Combined Cycle }\end{array}$ & $\begin{array}{c}5.90 \\
5.91 \%\end{array}$ & $\begin{array}{c}4.85 \\
6.00 \%\end{array}$ & $\begin{array}{c}5.41 \\
5.91 \%\end{array}$ & $\begin{array}{c}5.54 \\
5.91 \%\end{array}$ & $\begin{array}{c}5.87 \\
5.92 \%\end{array}$ & $\begin{array}{c}5.68 \\
5.99 \%\end{array}$ \\
\hline Levelized Cost & 6.06 & 5.14 & 5.65 & 5.72 & 6.03 & 5.89 \\
\hline $\begin{array}{l}\text { Int. Rate of Return } \\
\text { Combustion Turbine }\end{array}$ & $5.91 \%$ & $6.00 \%$ & $5.91 \%$ & $5.91 \%$ & $5.92 \%$ & $5.99 \%$ \\
\hline Levelized Cost & 9.13 & 7.77 & 8.40 & 8.61 & 9.10 & 8.97 \\
\hline $\begin{array}{l}\text { Int. Rate of Return } \\
\text { Nuclear }\end{array}$ & $5.85 \%$ & $6.00 \%$ & $5.85 \%$ & $5.85 \%$ & $5.87 \%$ & $5.98 \%$ \\
\hline Levelized Cost & 5.75 & 4.78 & 5.28 & 5.37 & 5.73 & 5.60 \\
\hline Int. Rate of Return & $5.88 \%$ & $6.00 \%$ & $5.88 \%$ & $5.88 \%$ & $5.89 \%$ & $5.98 \%$ \\
\hline
\end{tabular}


Table B.2

Ratemaking Simulation Results:

Levelized Cost and Internal Rate of Return, Investor-Owned Utilities

(Levelized Cost in e/kWh, IRR in \%)

\begin{tabular}{|c|c|c|c|c|}
\hline $\begin{array}{l}\text { GENERATING } \\
\text { ALTERNATIVE }\end{array}$ & $\begin{array}{l}\text { Reference } \\
\text { Base Tech } \\
\text { with Taxes }\end{array}$ & $\begin{array}{c}\text { CWIP } \\
\text { Allowed }\end{array}$ & $\begin{array}{c}\text { Flow-Through } \\
\text { Taxes }\end{array}$ & $\begin{array}{c}\text { No Fuel } \\
\text { Adjustment } \\
\text { Clause }\end{array}$ \\
\hline \multicolumn{5}{|l|}{ RENEWABLES } \\
\hline Levelized Cost & 6.05 & 6.06 & 6.19 & 6.05 \\
\hline Int. Rate of Return & $5.91 \%$ & $5.92 \%$ & $6.00 \%$ & $5.91 \%$ \\
\hline \multicolumn{5}{|l|}{ Biomass-Waste } \\
\hline Levelized Cost & 6.49 & 6.50 & 6.63 & 6.49 \\
\hline Int. Rate of Return & $5.91 \%$ & $5.92 \%$ & $6.00 \%$ & $5.91 \%$ \\
\hline \multicolumn{5}{|l|}{ Geothermal } \\
\hline Levelized Cost & 6.16 & 6.17 & 6.54 & 6.16 \\
\hline Int. Rate of Return & $5.70 \%$ & $5.69 \%$ & $6.00 \%$ & $5.70 \%$ \\
\hline \multicolumn{5}{|l|}{ Hydro } \\
\hline Levelized Cost & 2.90 & 2.91 & 3.22 & 2.90 \\
\hline Int. Rate of Return & $5.85 \%$ & $5.86 \%$ & $6.00 \%$ & $5.85 \%$ \\
\hline \multicolumn{5}{|l|}{ Solar-Photovoltaic } \\
\hline Levelized Cost & 32.37 & 32.39 & 36.48 & 32.37 \\
\hline Int. Rate of Return & $5.65 \%$ & $5.65 \%$ & $6.00 \%$ & $5.65 \%$ \\
\hline \multicolumn{5}{|l|}{ Solar-Thermal } \\
\hline Levelized Cost & 16.33 & 16.34 & 18.14 & 16.33 \\
\hline Int. Rate of Return & $5.66 \%$ & $5.65 \%$ & $6.00 \%$ & $5.66 \%$ \\
\hline \multicolumn{5}{|l|}{ Wind } \\
\hline Levelized Cost & 3.30 & 3.31 & 3.73 & 3.30 \\
\hline Int. Rate of Return & $5.69 \%$ & $5.69 \%$ & $6.00 \%$ & $5.69 \%$ \\
\hline \multicolumn{5}{|l|}{ CONVENTIONAL } \\
\hline \multicolumn{5}{|l|}{ Coal } \\
\hline Levelized Cost & 5.90 & 5.92 & 6.05 & 5.90 \\
\hline Int. Rate of Return & $5.91 \%$ & $5.92 \%$ & $6.00 \%$ & $5.91 \%$ \\
\hline \multicolumn{5}{|l|}{ Combined Cycle } \\
\hline Levelized Cost & 6.06 & 6.07 & 6.19 & 6.06 \\
\hline Int. Rate of Return & $5.91 \%$ & $5.92 \%$ & $6.00 \%$ & $5.88 \%$ \\
\hline \multicolumn{5}{|l|}{ Combustion Turbine } \\
\hline Levelized Cost & 9.13 & 9.13 & 9.34 & 9.12 \\
\hline Int. Rate of Return & $5.85 \%$ & $5.85 \%$ & $6.00 \%$ & $5.82 \%$ \\
\hline \multicolumn{5}{|l|}{ Nuclear } \\
\hline Levelized Cost & 5.75 & 5.77 & 5.90 & 5.75 \\
\hline Int. Rate of Return & $5.88 \%$ & $5.89 \%$ & $6.00 \%$ & $5.88 \%$ \\
\hline
\end{tabular}

B-4 
Table B.3

Summary of Federal Income Tax Simulation Results:

Levelized Cost and Internal Rate of Return, Investor-Owned Utilities

(Levelized Cost in $\mathbf{c / k W h , ~ I R R ~ i n ~ \% ) ~}$

\begin{tabular}{|c|c|c|c|c|c|}
\hline $\begin{array}{l}\text { GENERATING } \\
\text { ALTERNATIVE }\end{array}$ & Reference & $\begin{array}{l}\text { No Credits } \\
\text { and No Fed. } \\
\text { Income Tax }\end{array}$ & $\begin{array}{l}\text { Tax Life = } \\
\text { Book Life }\end{array}$ & No Credits & $\begin{array}{l}\text { No Credits or } \\
\text { Accel Dep. }\end{array}$ \\
\hline \multicolumn{6}{|l|}{ RENEWABLES } \\
\hline \multicolumn{6}{|l|}{ Biomass-Plantation } \\
\hline Levelized Cost & 6.05 & 7.08 & 6.22 & 7.29 & 7.46 \\
\hline Int. Rate of Return & $5.91 \%$ & $5.99 \%$ & $5.99 \%$ & $5.91 \%$ & $5.99 \%$ \\
\hline \multicolumn{6}{|l|}{ Biomass-Waste } \\
\hline Levelized Cost & 6.49 & 6.29 & 6.67 & 6.49 & 6.67 \\
\hline Int. Rate of Return & $5.91 \%$ & $5.99 \%$ & $5.99 \%$ & $5.91 \%$ & $5.99 \%$ \\
\hline \multicolumn{6}{|l|}{ Geothermal } \\
\hline Levelized Cost & 6.16 & 6.30 & 6.84 & 6.16 & 6.84 \\
\hline Int. Rate of Return & $5.70 \%$ & $5.96 \%$ & $5.99 \%$ & $5.70 \%$ & $5.99 \%$ \\
\hline \multicolumn{6}{|l|}{ Hydro } \\
\hline Levelized Cost & 2.90 & 2.79 & 3.24 & 2.90 & 3.24 \\
\hline Int. Rate of Return & $5.85 \%$ & $5.98 \%$ & $5.98 \%$ & $5.85 \%$ & $5.98 \%$ \\
\hline \multicolumn{6}{|l|}{ Solar-Photovoltaic } \\
\hline Levelized Cost & 32.37 & 34.14 & 39.85 & 32.37 & 39.85 \\
\hline Int. Rate of Return & $5.65 \%$ & $5.96 \%$ & $6.00 \%$ & $5.65 \%$ & $6.00 \%$ \\
\hline \multicolumn{6}{|l|}{ Solar-Thermal } \\
\hline Levelized Cost & 16.33 & 17.10 & 19.62 & 16.33 & 19.62 \\
\hline Int. Rate of Return & $5.66 \%$ & $5.96 \%$ & $6.00 \%$ & $5.66 \%$ & $6.00 \%$ \\
\hline \multicolumn{6}{|l|}{ Wind } \\
\hline Levelized Cost & 3.30 & 4.68 & 4.08 & 4.54 & 5.31 \\
\hline Int. Rate of Return & $5.69 \%$ & $5.96 \%$ & $6.00 \%$ & $5.69 \%$ & $6.00 \%$ \\
\hline \multicolumn{6}{|l|}{ CONVENTIONAL } \\
\hline \multicolumn{6}{|l|}{ Coal } \\
\hline Levelized Cost & 5.90 & 5.68 & 6.08 & 5.90 & 6.08 \\
\hline Int. Rate of Return & $5.91 \%$ & $5.99 \%$ & $5.99 \%$ & $5.91 \%$ & $5.99 \%$ \\
\hline \multicolumn{6}{|l|}{ Combined Cycle } \\
\hline Levelized Cost & 6.06 & 5.89 & 6.21 & 6.06 & 6.21 \\
\hline Int. Rate of Return & $5.91 \%$ & $5.99 \%$ & $5.99 \%$ & $5.91 \%$ & $5.99 \%$ \\
\hline \multicolumn{6}{|l|}{ Combustion Turbine } \\
\hline Levelized Cost & 9.13 & 8.97 & 9.53 & 9.13 & 9.53 \\
\hline Int. Rate of Return & $5.85 \%$ & $5.98 \%$ & $6.00 \%$ & $5.85 \%$ & $6.00 \%$ \\
\hline \multicolumn{6}{|l|}{ Nuclear } \\
\hline Levelized Cost & 5.75 & 5.60 & 6.01 & 5.75 & 6.01 \\
\hline Int. Rate of Return & $5.88 \%$ & $5.98 \%$ & $5.98 \%$ & $5.88 \%$ & $5.98 \%$ \\
\hline
\end{tabular}


Table B.4

Summary of Property Tax Simulation Results:

Levelized Cost and Internal Rate of Return,

Investor-Owned Utilities

(Levelized Cost in e/kWh, IRR in \%)

\begin{tabular}{|c|c|c|c|c|c|}
\hline $\begin{array}{l}\text { GENERATING } \\
\text { ALTERNATIVE }\end{array}$ & $\begin{array}{c}\text { No } \\
\text { Property Tax }\end{array}$ & $\begin{array}{c}\text { Tax Based on } \\
\text { Net Book Value } \\
\text { (Reference) }\end{array}$ & $\begin{array}{c}\text { Tax Based } \\
\text { on Gross } \\
\text { Book Value }\end{array}$ & $\begin{array}{l}\text { Tax Based } \\
\text { on Future } \\
\text { Cash Flow } \\
\end{array}$ & $\begin{array}{c}\text { Tax Based on } \\
\text { Net Book Value + } \\
\text { No Tax on Land }\end{array}$ \\
\hline \multicolumn{6}{|l|}{ RENEWABLES } \\
\hline \multicolumn{6}{|l|}{ Biomass-Plantation } \\
\hline Levelized Cost & 5.57 & 6.05 & 6.34 & 6.06 & 6.01 \\
\hline Int. Rate of Retum & $5.91 \%$ & $5.91 \%$ & $5.91 \%$ & $5.91 \%$ & $5.91 \%$ \\
\hline \multicolumn{6}{|l|}{ Biomass-Waste } \\
\hline Levelized Cost & 6.02 & 6.49 & 6.78 & 6.50 & 6.46 \\
\hline Int. Rate of Retum & $5.91 \%$ & $5.91 \%$ & $5.91 \%$ & $5.91 \%$ & $5.91 \%$ \\
\hline \multicolumn{6}{|l|}{ Geothermal } \\
\hline Levelized Cost & 5.53 & 6.16 & 6.55 & 6.04 & 6.11 \\
\hline Int. Rate of Retum & $5.70 \%$ & $5.70 \%$ & $5.70 \%$ & $5.70 \%$ & $5.70 \%$ \\
\hline \multicolumn{6}{|l|}{ Hydro } \\
\hline Levelized Cost & 2.34 & 2.90 & 3.15 & 2.89 & 2.86 \\
\hline Int. Rate of Retum & $5.85 \%$ & $5.85 \%$ & $5.85 \%$ & $5.85 \%$ & $5.85 \%$ \\
\hline \multicolumn{6}{|l|}{ Solar-Photovoltaic } \\
\hline Levelized Cost & 25.43 & 32.37 & 36.63 & 30.58 & 31.84 \\
\hline Int. Rate of Retum & $5.65 \%$ & $5.65 \%$ & $5.65 \%$ & $5.65 \%$ & $5.65 \%$ \\
\hline \multicolumn{6}{|l|}{ Solar-Thermal } \\
\hline Levelized Cost & 13.27 & 16.33 & 18.20 & 15.55 & 16.09 \\
\hline Int. Rate of Retum & $5.66 \%$ & $5.66 \%$ & $5.66 \%$ & $5.66 \%$ & $5.66 \%$ \\
\hline \multicolumn{6}{|l|}{ Wind } \\
\hline Levelized Cost & 2.52 & 3.30 & 3.74 & 3.13 & 3.19 \\
\hline Int. Rate of Retum & $5.69 \%$ & $5.69 \%$ & $5.69 \%$ & $5.69 \%$ & $5.69 \%$ \\
\hline \multicolumn{6}{|l|}{ CONVENTIONAL } \\
\hline \multicolumn{6}{|l|}{ Coal } \\
\hline Levelized Cost & 5.41 & 5.90 & 6.21 & 5.93 & 5.87 \\
\hline Int. Rate of Retum & $5.91 \%$ & $5.91 \%$ & $5.91 \%$ & $5.91 \%$ & $5.91 \%$ \\
\hline \multicolumn{6}{|l|}{ Combined Cycle } \\
\hline Levelized Cost & 5.65 & 6.06 & 6.32 & 6.07 & 6.03 \\
\hline Int. Rate of Retum & $5.91 \%$ & $5.91 \%$ & $5.91 \%$ & $5.91 \%$ & $5.91 \%$ \\
\hline \multicolumn{6}{|l|}{ Combustion Turbine } \\
\hline Levelized Cost & 8.40 & 9.13 & 9.57 & 9.06 & 9.07 \\
\hline Int. Rate of Retum & $5.85 \%$ & $5.85 \%$ & $5.85 \%$ & $5.85 \%$ & $5.85 \%$ \\
\hline \multicolumn{6}{|l|}{ Nuclear } \\
\hline Levelized Cost & 5.28 & 5.75 & 6.04 & 5.77 & 5.72 \\
\hline Int. Rate of Retum & $5.88 \%$ & $5.88 \%$ & $5.88 \%$ & $5.88 \%$ & $5.88 \%$ \\
\hline
\end{tabular}


Table B.5

Summary of State Input Tax Effects:

Levelized Cost and Internal Rate of Return, Investor-Owned Utilities

(Levelized Cost in $\mathrm{c} / \mathrm{kWh}$, IRR in \%)

\begin{tabular}{|c|c|c|c|c|c|c|}
\hline $\begin{array}{l}\text { GENERATING } \\
\text { ALTERNATIVE }\end{array}$ & Reference & No Input Taxes & No Labor Tax & No Energy Tax & No Material Tax & No Land Tax \\
\hline \multicolumn{7}{|l|}{ RENEWABLES } \\
\hline \multicolumn{7}{|l|}{ Biomass-Plantation } \\
\hline Levelized Cost & 6.05 & 5.63 & 5.90 & 5.87 & 5.97 & 6.04 \\
\hline Int. Rate of Return & $5.91 \%$ & $5.91 \%$ & $5.91 \%$ & $5.91 \%$ & $5.91 \%$ & $5.91 \%$ \\
\hline \multicolumn{7}{|l|}{ Biomass-Waste } \\
\hline Levelized Cost & 6.49 & 6.11 & 6.35 & 6.35 & 6.42 & 6.49 \\
\hline Int. Rate of Return & $5.91 \%$ & $5.91 \%$ & $5.91 \%$ & $5.91 \%$ & $5.91 \%$ & $5.91 \%$ \\
\hline \multicolumn{7}{|l|}{ Geothermal } \\
\hline Levelized Cost & 6.16 & 5.75 & 5.90 & 6.16 & 6.02 & 6.15 \\
\hline Int. Rate of Return & $5.70 \%$ & $5.70 \%$ & $5.70 \%$ & $5.70 \%$ & $5.70 \%$ & $5.70 \%$ \\
\hline \multicolumn{7}{|l|}{ Hydro } \\
\hline Levelized Cost & 2.90 & 2.71 & 2.78 & 2.89 & 2.84 & 2.89 \\
\hline Int. Rate of Return & $5.85 \%$ & $5.85 \%$ & $5.85 \%$ & $5.85 \%$ & $5.85 \%$ & $5.85 \%$ \\
\hline \multicolumn{7}{|l|}{ Solar-Photovoltaic } \\
\hline Levelized Cost & 32.37 & 30.23 & 31.07 & 32.30 & 31.69 & 32.29 \\
\hline Int. Rate of Return & $5.65 \%$ & $5.66 \%$ & $5.66 \%$ & $5.66 \%$ & $5.66 \%$ & $5.66 \%$ \\
\hline \multicolumn{7}{|l|}{ Solar-Thermal } \\
\hline Levelized Cost & 16.33 & 15.24 & 15.66 & 16.29 & 15.98 & 16.29 \\
\hline Int. Rate of Return & $5.66 \%$ & $5.66 \%$ & $5.66 \%$ & $5.66 \%$ & $5.66 \%$ & $5.66 \%$ \\
\hline \multicolumn{7}{|l|}{ Wind } \\
\hline Levelized Cost & 3.30 & 3.00 & 3.12 & 3.30 & 3.21 & 3.29 \\
\hline Int. Rate of Return & $5.69 \%$ & $5.69 \%$ & $5.69 \%$ & $5.69 \%$ & $5.69 \%$ & $5.69 \%$ \\
\hline \multicolumn{7}{|l|}{ CONVENTIONAL } \\
\hline \multicolumn{7}{|l|}{ Coal } \\
\hline Levelized Cost & 5.90 & 5.54 & 5.73 & 5.81 & 5.81 & 5.90 \\
\hline Int. Rate of Return & $5.91 \%$ & $5.91 \%$ & $5.91 \%$ & $5.91 \%$ & $5.91 \%$ & $5.91 \%$ \\
\hline \multicolumn{7}{|l|}{ Combined Cycle } \\
\hline Levelized Cost & 6.06 & 5.72 & 5.94 & 5.90 & 6.00 & 6.06 \\
\hline Int. Rate of Return & $5.91 \%$ & $5.91 \%$ & $5.91 \%$ & $5.91 \%$ & $5.91 \%$ & $5.91 \%$ \\
\hline \multicolumn{7}{|l|}{ Combustion Turbine } \\
\hline Levelized Cost & 9.13 & 8.61 & 8.95 & 8.89 & 9.04 & 9.12 \\
\hline Int. Rate of Return & $5.85 \%$ & $5.85 \%$ & $5.85 \%$ & $5.85 \%$ & $5.85 \%$ & $5.85 \%$ \\
\hline \multicolumn{7}{|l|}{ Nuclear } \\
\hline Levelized Cost & 5.75 & 5.37 & 5.53 & 5.72 & 5.64 & 5.75 \\
\hline Int Rate of Relurn & $5.88 \%$ & $5.88 \%$ & $5.88 \%$ & $5.88 \%$ & $5.88 \%$ & $5.88 \%$ \\
\hline
\end{tabular}


Table B.6

Tax Simulation Results:

Internal Rate of Return and Internal Rate of Return-Equity, Nonutility Generators

\begin{tabular}{|c|c|c|c|c|c|c|c|}
\hline $\begin{array}{l}\text { GENERATING } \\
\text { ALTERNATIVE }\end{array}$ & $\begin{array}{l}\text { Reference } \\
\text { Base Tech } \\
\text { with Taxes }\end{array}$ & $\begin{array}{l}\text { No Taxes } \\
\text { or Credits } \\
\end{array}$ & $\begin{array}{c}\text { No } \\
\text { Property Taxes }\end{array}$ & $\begin{array}{c}\text { No } \\
\text { Inpul Taxes } \\
\end{array}$ & $\begin{array}{c}\text { No State } \\
\text { Income Taxes } \\
\end{array}$ & $\begin{array}{l}\text { No Credils } \\
\text { and No Fed. } \\
\text { Income Tax }\end{array}$ & $\begin{array}{c}\text { Alternative } \\
\text { Minimum Tax }\end{array}$ \\
\hline \multicolumn{8}{|l|}{ RENEWABLES } \\
\hline \multicolumn{8}{|l|}{ Biomass-Plantation } \\
\hline Int. Rate of Ritn \% & $7.93 \%$ & $5.19 \%$ & $9.79 \%$ & $9.55 \%$ & $7.54 \%$ & $1.43 \%$ & $5.43 \%$ \\
\hline IRR - Equity \% & $27.21 \%$ & $5.56 \%$ & $33.02 \%$ & $31.83 \%$ & $24.61 \%$ & a & $9.55 \%$ \\
\hline \multicolumn{8}{|l|}{ Biomass-Waste } \\
\hline Int. Rate of Ritn \% & $7.28 \%$ & $10.26 \%$ & $8.83 \%$ & $847 \%$ & $7.22 \%$ & $6.85 \%$ & $5.63 \%$ \\
\hline IRR - Equity \% & $17.38 \%$ & $21.03 \%$ & $24.41 \%$ & $22.02 \%$ & $16.02 \%$ & $10.49 \%$ & $7.44 \%$ \\
\hline \multicolumn{8}{|l|}{ Geothermal } \\
\hline int. Rate of Ritrn \% & $7.31 \%$ & $8.86 \%$ & $8.98 \%$ & $8.39 \%$ & $7.18 \%$ & $5.67 \%$ & $5.46 \%$ \\
\hline IRR - Equity \% & $22.11 \%$ & $16.60 \%$ & $29.72 \%$ & $26.31 \%$ & $19.81 \%$ & $6.93 \%$ & $7.30 \%$ \\
\hline \multicolumn{8}{|l|}{ Hydro } \\
\hline Int. Rate of Rtrn \% & $6.10 \%$ & $8.61 \%$ & $7.39 \%$ & $6.55 \%$ & $6.11 \%$ & $6.16 \%$ & $5.53 \%$ \\
\hline IRR - Equity \% & $8.57 \%$ & $15.11 \%$ & $13.02 \%$ & $10.01 \%$ & $8.48 \%$ & $7.98 \%$ & $6.59 \%$ \\
\hline \multicolumn{8}{|l|}{ Solar-Photovoltaic } \\
\hline Int. Rate of Rtrn \% & $7.33 \%$ & $8.16 \%$ & $9.33 \%$ & $7.94 \%$ & $7.15 \%$ & $5.30 \%$ & $5.19 \%$ \\
\hline IRR - Equity \% & $32.69 \%$ & $15.40 \%$ & $44.63 \%$ & $35.73 \%$ & $28.17 \%$ & $5.91 \%$ & $6.15 \%$ \\
\hline \multicolumn{8}{|l|}{ Solar-Thermal } \\
\hline Int. Rate of Rtrn \% & $7.36 \%$ & $8.30 \%$ & $9.35 \%$ & $8.05 \%$ & $7.18 \%$ & $5.34 \%$ & $5.23 \%$ \\
\hline IRR - Equity \% & $32.80 \%$ & $15.88 \%$ & $44.69 \%$ & $36.25 \%$ & $28.30 \%$ & $6.03 \%$ & $6.34 \%$ \\
\hline \multicolumn{8}{|l|}{ Wind } \\
\hline Int. Rate of Rtrn \% & $6.49 \%$ & $4.82 \%$ & $8.66 \%$ & $7.37 \%$ & $6.16 \%$ & $1.81 \%$ & $4.19 \%$ \\
\hline IRR - Equity \% & $26.09 \%$ & $4.41 \%$ & $36.81 \%$ & $30.37 \%$ & $21.67 \%$ & $a$ & a \\
\hline \multicolumn{8}{|l|}{ CONVENTIONAL } \\
\hline \multicolumn{8}{|l|}{ Coal } \\
\hline Int. Rate of Rtrn \% & $6.29 \%$ & $9.91 \%$ & $7.53 \%$ & $7.21 \%$ & $6.36 \%$ & $6.79 \%$ & $6.08 \%$ \\
\hline IRA - Equity \% & $9.39 \%$ & $18.97 \%$ & $13.59 \%$ & $12.20 \%$ & $9.49 \%$ & $10.10 \%$ & $8.56 \%$ \\
\hline \multicolumn{8}{|l|}{ Combined Cycle } \\
\hline Int. Rate of Rim \% & $6.56 \%$ & $11.71 \%$ & $8.17 \%$ & $7.89 \%$ & $6.65 \%$ & $7.28 \%$ & $6.43 \%$ \\
\hline IRA - Equity \% & $13.32 \%$ & $29.53 \%$ & $19.52 \%$ & $17.85 \%$ & $13.62 \%$ & $15.60 \%$ & $12.64 \%$ \\
\hline \multicolumn{8}{|l|}{ Combustion Turbine } \\
\hline Int. Rate of Ritn \% & $6.55 \%$ & $11.62 \%$ & $8.43 \%$ & $7.89 \%$ & $6.58 \%$ & $6.82 \%$ & $6.16 \%$ \\
\hline IRR - Equity \% & $15.53 \%$ & $34.85 \%$ & $24.10 \%$ & $20.84 \%$ & $15.50 \%$ & $15.32 \%$ & $13.35 \%$ \\
\hline \multicolumn{8}{|l|}{ Nuclear } \\
\hline Int. Rate of Rirn \% & $6.28 \%$ & $9.39 \%$ & $7.41 \%$ & $7.20 \%$ & $6.31 \%$ & $6.54 \%$ & $5.89 \%$ \\
\hline IRA - Equity \% & $9.13 \%$ & $16.50 \%$ & $12.78 \%$ & $11.84 \%$ & $9.11 \%$ & $9.01 \%$ & $7.76 \%$ \\
\hline
\end{tabular}

a Internal Rate of Return-Equity cannot be calculated for these cases because the equity cash flow protile is such that no discount rate will give a zero net present value over the entire lite of the project. 


\section{Table B.7}

Summary of Federal Income Tax Simulation Results: Internal Rate of Return and Internal Rate of Return-Equity, Nonutility Generators

\begin{tabular}{|c|c|c|c|c|c|}
\hline $\begin{array}{l}\text { GENERATING } \\
\text { ALTERNATIVE }\end{array}$ & Reference & $\begin{array}{l}\text { No Credits } \\
\text { and No Fed. } \\
\text { Income Tax }\end{array}$ & $\begin{array}{l}\text { Tax Life = } \\
\text { Book Life }\end{array}$ & No Tax Credits & $\begin{array}{c}\text { No Credits or } \\
\text { Accel Dep. }\end{array}$ \\
\hline \multicolumn{6}{|l|}{ RENEWABLES } \\
\hline \multicolumn{6}{|l|}{ Biomass-Plantation } \\
\hline Int. Rate of Rtrn \% & $7.93 \%$ & $1.43 \%$ & $6.10 \%$ & $2.89 \%$ & $2.21 \%$ \\
\hline IRR - Equity \% & $27.21 \%$ & a & $11.03 \%$ & $a$ & a \\
\hline \multicolumn{6}{|l|}{ Biomass-Waste } \\
\hline Int. Rate of Rtrn \% & $7.28 \%$ & $6.85 \%$ & $5.88 \%$ & $7.28 \%$ & $5.88 \%$ \\
\hline IRR - Equity \% & $17.38 \%$ & $10.49 \%$ & $7.72 \%$ & $17.38 \%$ & $7.72 \%$ \\
\hline \multicolumn{6}{|l|}{ Geothermal } \\
\hline Int. Rate of Rtrn \% & $6.26 \%$ & $4.40 \%$ & $4.92 \%$ & $5.28 \%$ & $4.19 \%$ \\
\hline IRR - Equity \% & $17.01 \%$ & $3.28 \%$ & $4.71 \%$ & $6.90 \%$ & $2.47 \%$ \\
\hline \multicolumn{6}{|l|}{ Hydro } \\
\hline Int. Rate of Rtrn \% & $6.10 \%$ & $6.16 \%$ & $5.50 \%$ & $6.10 \%$ & $5.50 \%$ \\
\hline IRR - Equity \% & $8.57 \%$ & $7.98 \%$ & $6.39 \%$ & $8.57 \%$ & $6.39 \%$ \\
\hline \multicolumn{6}{|l|}{ Solar-Photovoltaic } \\
\hline Int. Rate of Rtrn \% & $6.08 \%$ & $3.87 \%$ & $4.61 \%$ & $4.96 \%$ & $3.82 \%$ \\
\hline IRR - Equity \% & $25.15 \%$ & $1.66 \%$ & $3.48 \%$ & $4.63 \%$ & $1.24 \%$ \\
\hline \multicolumn{6}{|l|}{ Solar-Thermal } \\
\hline Int. Rate of Rtrn \% & $6.12 \%$ & $3.91 \%$ & $4.64 \%$ & $4.99 \%$ & $3.85 \%$ \\
\hline IRR - Equity \% & $25.33 \%$ & $1.78 \%$ & $3.59 \%$ & $4.94 \%$ & $1.33 \%$ \\
\hline \multicolumn{6}{|l|}{ Wind } \\
\hline Int. Rate of Rtrn \% & $6.49 \%$ & $1.81 \%$ & $4.94 \%$ & $3.19 \%$ & $2.47 \%$ \\
\hline IRR - Equity \% & $26.09 \%$ & a & $4.68 \%$ & a & a \\
\hline \multicolumn{6}{|l|}{ CONVENTIONAL } \\
\hline \multicolumn{6}{|l|}{ Coal } \\
\hline Int. Rate of Rtrn \% & $6.29 \%$ & $6.79 \%$ & $5.93 \%$ & $6.29 \%$ & $5.93 \%$ \\
\hline IRR - Equity \% & $9.39 \%$ & $10.10 \%$ & $7.90 \%$ & $9.39 \%$ & $7.90 \%$ \\
\hline \multicolumn{6}{|l|}{ Combined Cycle } \\
\hline Int. Rate of Rtrn \% & $6.56 \%$ & $7.28 \%$ & $6.07 \%$ & $6.56 \%$ & $6.07 \%$ \\
\hline IRR - Equity \% & $13.32 \%$ & $15.60 \%$ & $10.38 \%$ & $13.32 \%$ & $10.38 \%$ \\
\hline \multicolumn{6}{|l|}{ Combustion Turbine } \\
\hline Int. Rate of Rtrn \% & $6.55 \%$ & $6.82 \%$ & $5.70 \%$ & $6.55 \%$ & $5.70 \%$ \\
\hline IRR - Equity \% & $15.53 \%$ & $15.32 \%$ & $9.04 \%$ & $15.53 \%$ & $9.04 \%$ \\
\hline \multicolumn{6}{|l|}{ Nuclear } \\
\hline Int. Rate of Rtrn \% & $6.28 \%$ & $6.54 \%$ & $5.77 \%$ & $6.28 \%$ & $5.77 \%$ \\
\hline IRR - Equity \% & $9.13 \%$ & $9.01 \%$ & $7.21 \%$ & $9.13 \%$ & $7.21 \%$ \\
\hline
\end{tabular}

a Internal Rate of Retum-Equity cannot be calculated for these cases because the equity cash flow profile is such that no discount rate will give a zero net present value over the entire life of the project. 
Table B.8

Summary of Alternative Minimum Tax Results:

Internal Rate of Return and Internal Rate of Return-Equity, Nonutility Generators

\begin{tabular}{|c|c|c|c|c|}
\hline $\begin{array}{l}\text { GENERATING } \\
\text { ALTERNATIVE }\end{array}$ & Reference & $\begin{array}{c}\text { Alternative } \\
\text { Minimum Tax }\end{array}$ & $\begin{array}{l}\text { Carry Forward } \\
\text { of Tax Losses }\end{array}$ & $\begin{array}{l}\text { Alternative } \\
\text { Min. Tax and } \\
\text { Carry Fonward }\end{array}$ \\
\hline \multicolumn{5}{|l|}{ RENEWABLES } \\
\hline \multicolumn{5}{|l|}{ Biomass-Plantation } \\
\hline Int. Rate of Rtrn \% & $7.93 \%$ & $5.43 \%$ & $1.14 \%$ & $1.14 \%$ \\
\hline IRR - Equity \% & $27.21 \%$ & $9.55 \%$ & $\mathbf{a}$ & $a$ \\
\hline \multicolumn{5}{|l|}{ Biomass-Waste } \\
\hline Int. Rate of Rtrn \% & $7.28 \%$ & $5.63 \%$ & $6.13 \%$ & $5.40 \%$ \\
\hline IRR - Equity \% & $17.38 \%$ & $7.44 \%$ & $8.59 \%$ & $6.36 \%$ \\
\hline \multicolumn{5}{|l|}{ Geothermal } \\
\hline Int. Rate of Rtrn \% & $6.26 \%$ & $4.37 \%$ & $3.97 \%$ & $3.65 \%$ \\
\hline IRR - Equity \% & $17.01 \%$ & $1.73 \%$ & $1.99 \%$ & $0.69 \%$ \\
\hline \multicolumn{5}{|l|}{ Hydro } \\
\hline Int. Rate of Rtrn \% & $6.10 \%$ & $5.53 \%$ & $5.61 \%$ & $5.44 \%$ \\
\hline IRR - Equity \% & $8.57 \%$ & $6.59 \%$ & $6.73 \%$ & $6.26 \%$ \\
\hline \multicolumn{5}{|l|}{ Solar-Photovoltaic } \\
\hline Int. Rate of Rtrn \% & $6.08 \%$ & $3.94 \%$ & $3.42 \%$ & $3.15 \%$ \\
\hline IRR - Equity \% & $25.15 \%$ & a & $0.28 \%$ & $a$ \\
\hline \multicolumn{5}{|l|}{ Solar-Thermal } \\
\hline Int. Rate of Rtrn \% & $6.12 \%$ & $3.98 \%$ & $3.46 \%$ & $3.19 \%$ \\
\hline IRR - Equity \% & $25.33 \%$ & a & $0.41 \%$ & a \\
\hline \multicolumn{5}{|l|}{ Wind } \\
\hline Int. Rate of Rtrn \% & $6.49 \%$ & $4.19 \%$ & $1.54 \%$ & $1.54 \%$ \\
\hline IRR - Equity \% & $26.09 \%$ & $\mathbf{a}$ & a & a \\
\hline \multicolumn{5}{|l|}{ CONVENTIONAL } \\
\hline \multicolumn{5}{|l|}{ Coal } \\
\hline Int. Rate of Rtrn \% & $6.29 \%$ & $6.08 \%$ & $6.17 \%$ & $6.04 \%$ \\
\hline IRR - Equity \% & $9.39 \%$ & $8.56 \%$ & $8.75 \%$ & $8.35 \%$ \\
\hline \multicolumn{5}{|l|}{ Combined Cycle } \\
\hline Int. Rate of Rtrn \% & $6.56 \%$ & $6.43 \%$ & $6.54 \%$ & $6.42 \%$ \\
\hline IRR - Equity \% & $13.32 \%$ & $12.64 \%$ & $13.12 \%$ & $12.52 \%$ \\
\hline \multicolumn{5}{|l|}{ Combustion Turbine } \\
\hline Int. Rate of Rtrn \% & $6.55 \%$ & $6.16 \%$ & $6.43 \%$ & $6.14 \%$ \\
\hline IRR - Equity \% & $15.53 \%$ & $13.35 \%$ & $14.37 \%$ & $13.15 \%$ \\
\hline \multicolumn{5}{|l|}{ Nuclear } \\
\hline Int. Rate of Rtrn \% & $6.28 \%$ & $5.89 \%$ & $5.89 \%$ & $5.75 \%$ \\
\hline IRR - Equity \% & $9.13 \%$ & $7.76 \%$ & $7.58 \%$ & $7.20 \%$ \\
\hline
\end{tabular}

a Intemal Rate of Retum-Equity cannot be calculated for these cases because the equity cash flow profile is such that no discount rate will give a zero net present value over the entire life of the project.

B-10 
Table B.9

Levelized Cost Components ( $\boldsymbol{\epsilon} / \mathbf{k W h}$ ),

Biomass/Dedicated Plant

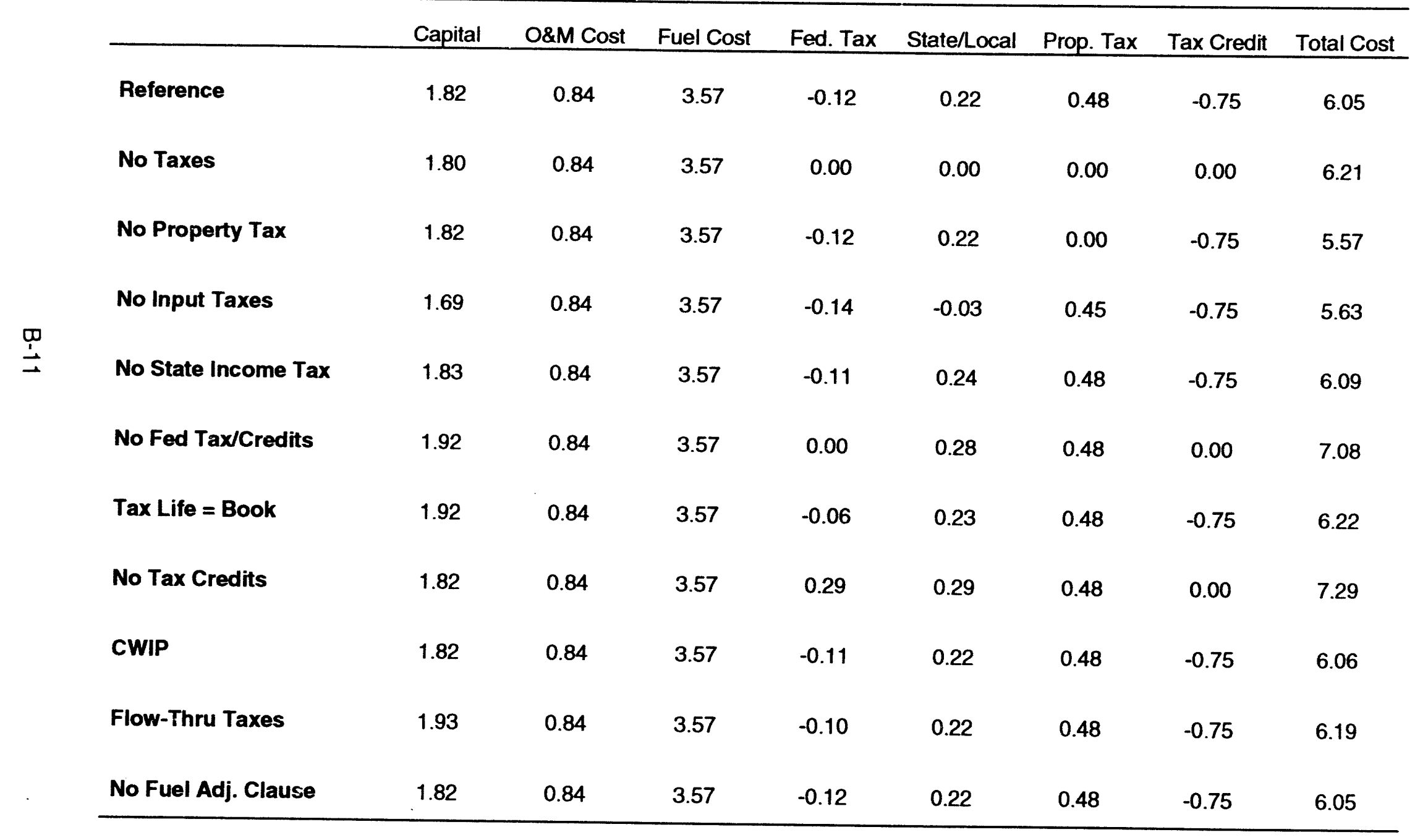


Table B.10

Levelized Cost Components ( $₫ / k W h)$, Biomass/Waste Wood

\begin{tabular}{|c|c|c|c|c|c|c|c|c|}
\hline & Capital & O\&M Cost & Fuel Cost & Fed. Tax & State/Local & Prop. Tax & Tax Credit & Total Cost \\
\hline Reference & 1.82 & 0.84 & 2.82 & 0.29 & 0.26 & 0.48 & 0.00 & 6.49 \\
\hline No Taxes & 1.80 & 0.84 & 2.82 & 0.00 & 0.00 & 0.00 & 0.00 & 5.46 \\
\hline No Property Tax & 1.82 & 0.84 & 2.82 & 0.29 & 0.26 & 0.00 & 0.00 & 6.02 \\
\hline No Input Taxes & 1.69 & 0.84 & 2.82 & 0.27 & 0.05 & 0.45 & 0.00 & 6.11 \\
\hline No State Income Tax & 1.83 & 0.84 & 2.82 & 0.29 & 0.20 & 0.48 & 0.00 & 6.46 \\
\hline No Fed Tax/Credits & 1.92 & 0.84 & 2.82 & 0.00 & 0.24 & 0.48 & 0.00 & 6.29 \\
\hline Tax Life = Book & 1.92 & 0.84 & 2.82 & 0.35 & 0.27 & 0.48 & 0.00 & 6.67 \\
\hline No Tax Credits & 1.82 & 0.84 & 2.82 & 0.29 & 0.26 & 0.48 & 0.00 & 6.49 \\
\hline CWIP & 1.82 & 0.84 & 2.82 & 0.29 & 0.26 & 0.48 & 0.00 & 6.50 \\
\hline Flow-Thru Taxes & 1.93 & 0.84 & 2.82 & 0.31 & 0.26 & 0.48 & 0.00 & 6.63 \\
\hline No Fuel Adj. Clause & 1.82 & 0.84 & 2.82 & 0.29 & 0.26 & 0.48 & 0.00 & 6.49 \\
\hline
\end{tabular}


Table B.11

Levelized Cost Components ( $\mathrm{c} / \mathrm{kWh}$ ),

Geothermal

\begin{tabular}{|c|c|c|c|c|c|c|c|c|}
\hline & Capital & O\&M Cost & Fuel Cost & Fed. Tax & State/Local & Prop Tax & Tax Credit & Total Cost \\
\hline Reference & 2.14 & 2.90 & 0.00 & 0.24 & 0.26 & 0.63 & 0.00 & 6.16 \\
\hline No Taxes & 2.39 & 2.90 & 0.00 & 0.00 & 0.00 & 0.00 & 0.00 & 5.29 \\
\hline No Property Tax & 2.14 & 2.90 & 0.00 & 0.24 & 0.26 & 0.00 & 0.00 & 5.53 \\
\hline No Input Taxes & 2.00 & 2.90 & 0.00 & 0.23 & 0.04 & 0.59 & 0.00 & 5.75 \\
\hline No State Income Tax & 2.18 & 2.90 & 0.00 & 0.26 & 0.22 & 0.63 & 0.00 & 6.19 \\
\hline No Fed Tax/Credits & 2.50 & 2.90 & 0.00 & 0.00 & 0.27 & 0.63 & 0.00 & 6.30 \\
\hline Tax Life = Book & 2.55 & 2.90 & 0.00 & 0.46 & 0.30 & 0.63 & 0.00 & 6.84 \\
\hline No Tax Credits & 2.14 & 2.90 & 0.00 & 0.24 & 0.26 & 0.63 & 0.00 & 6.16 \\
\hline CWIP & 2.14 & 2.90 & 0.00 & 0.24 & 0.26 & 0.63 & 0.00 & 6.17 \\
\hline Flow-Thru Taxes & 2.57 & 2.90 & 0.00 & 0.19 & 0.25 & 0.63 & 0.00 & 6.54 \\
\hline No Fuel Adj. Clause & 2.14 & 2.90 & 0.00 & 0.24 & 0.26 & 0.63 & 0.00 & 6.16 \\
\hline
\end{tabular}


Table B.12

Levelized Cost Components ( $₫ / \mathbf{k W h})$,

Hydro

\begin{tabular}{|c|c|c|c|c|c|c|c|c|}
\hline & Capital & O\&M Cost & Fuel Cost & Fed. Tax & State/Local & Prop. Tax & Tax Credit & Total Cost \\
\hline Reference & 1.62 & 0.34 & 0.00 & 0.30 & 0.08 & 0.56 & 0.00 & 2.90 \\
\hline No Taxes & 1.73 & 0.34 & 0.00 & 0.00 & 0.00 & 0.00 & 0.00 & 2.07 \\
\hline No Property Tax & 1.62 & 0.34 & 0.00 & 0.30 & 0.08 & 0.00 & 0.00 & 2.34 \\
\hline No Input Taxes & 1.52 & 0.34 & 0.00 & 0.28 & 0.05 & 0.52 & 0.00 & 2.71 \\
\hline No State Income Tax & 1.65 & 0.34 & 0.00 & 0.31 & 0.03 & 0.56 & 0.00 & 2.88 \\
\hline No Fed Tax/Credits & 1.82 & 0.34 & 0.00 & 0.00 & 0.07 & 0.56 & 0.00 & 2.79 \\
\hline Tax Life = Book & 1.83 & 0.34 & 0.00 & 0.41 & 0.10 & 0.56 & 0.00 & 3.24 \\
\hline No Tax Credits & 1.62 & 0.34 & 0.00 & 0.30 & 0.08 & 0.56 & 0.00 & 2.90 \\
\hline CWIP & 1.63 & 0.34 & 0.00 & 0.30 & 0.08 & 0.56 & 0.00 & 2.91 \\
\hline Flow-Thru Taxes & 1.86 & 0.34 & 0.00 & 0.37 & 0.09 & 0.56 & $0.0 \mathrm{C}$ & 3.22 \\
\hline No Fuel Adj. Clause & 1.62 & 0.34 & 0.00 & 0.30 & 0.08 & 0.56 & 0.00 & 2.90 \\
\hline
\end{tabular}


Table B.13

Levelized Cost Components ( $₫ / \mathbf{k W h})$,

Solar/Photovoltaic

\begin{tabular}{|c|c|c|c|c|c|c|c|c|}
\hline & Capital & O\&M Cost & Fuel Cost & Fed. Tax & State/Lccal & Prop Tax & Tax Credit & Total Cost \\
\hline Reference & 22.28 & 0.47 & 0.00 & 2.26 & 0.42 & 6.95 & 0.00 & 32.37 \\
\hline No Taxes & 25.07 & 0.47 & 0.00 & 0.00 & 0.00 & 0.00 & 0.00 & 25.53 \\
\hline No Property Tax & 22.28 & 0.47 & 0.00 & 2.26 & 0.42 & 0.00 & 0.00 & 25.43 \\
\hline No Input Taxes & 20.78 & 0.47 & 0.00 & 2.13 & 0.36 & 6.49 & 0.00 & 30.23 \\
\hline No State Income Tax & 22.74 & 0.47 & 0.00 & 2.49 & 0.03 & 6.95 & 0.00 & 32.68 \\
\hline No Fed Tax/Credits & 26.18 & 0.47 & 0.00 & 0.00 & 0.55 & 6.95 & 0.00 & 34.14 \\
\hline Tax Life = Book & 26.85 & 0.47 & 0.00 & 4.70 & 0.89 & 6.95 & 0.00 & 39.85 \\
\hline No Tax Credits & 22.28 & 0.47 & 0.00 & 2.26 & 0.42 & 6.95 & 0.00 & 32.37 \\
\hline CWIP & 22.28 & 0.47 & 0.00 & 2.27 & 0.42 & 6.95 & 0.00 & 32.39 \\
\hline Flow-Thru Taxes & 26.89 & 0.47 & 0.00 & 1.81 & 0.36 & 6.95 & 0.00 & 36.48 \\
\hline No Fuel Adj. Clause & 22.28 & 0.47 & 0.00 & 2.26 & 0.42 & 6.95 & 0.00 & 32.37 \\
\hline
\end{tabular}


Table B.14

Levelized Cost Components ( $\epsilon / \mathrm{kWh}$ ),

Solar/Thermal

\begin{tabular}{|c|c|c|c|c|c|c|c|c|}
\hline & Capital & O\&M Cost & Fuel Cost & Fed. Tax & State/Local & Prop Tax & Tax Credit & Total Cost \\
\hline Reference & 9.83 & 2.10 & 0.00 & 1.00 & 0.33 & 3.06 & 0.00 & 16.33 \\
\hline No Taxes & 11.06 & 2.10 & 0.00 & 0.00 & 0.00 & 0.00 & 0.00 & 13.17 \\
\hline No Property Tax & 9.83 & 2.10 & 0.00 & 1.00 & 0.33 & 0.00 & 0.00 & 13.27 \\
\hline No Input Taxes & 9.17 & 2.10 & 0.00 & 0.94 & 0.16 & 2.86 & 0.00 & 15.24 \\
\hline & & & & & & & & \\
\hline No State Income Tax & 10.04 & 2.10 & 0.00 & 1.10 & 0.16 & 3.06 & 0.00 & 16.46 \\
\hline No Fed Tax/Credits & 11.55 & 2.10 & 0.00 & 0.00 & 0.38 & 3.06 & 0.00 & 17.10 \\
\hline Tax Life = Book & 11.85 & 2.10 & 0.00 & 2.08 & 0.53 & 3.06 & 0.00 & 19.62 \\
\hline No Tax Credits & 9.83 & 2.10 & 0.00 & 1.00 & 0.33 & 3.06 & 0.00 & 16.33 \\
\hline CWIP & 9.84 & 2.10 & 0.00 & 1.01 & 0.33 & 3.06 & 0.00 & 16.34 \\
\hline Flow-Thru Taxes & 11.87 & 2.10 & 0.00 & 0.80 & 0.30 & 3.06 & 0.00 & 18.14 \\
\hline No Fuel Adj. Clause & 9.83 & $2.10^{\circ}$ & 0.00 & 1.00 & 0.33 & 3.06 & 0.00 & 16.33 \\
\hline
\end{tabular}


Table B.15

Levelized Cost Components ( $₫ / \mathbf{k W h})$,

Wind

\begin{tabular}{|c|c|c|c|c|c|c|c|c|}
\hline & Capital & O\&M Cost & Fuel Cost & Fed. Tax & State/Local & Prop. Tax & Tax Credit & Total Cost \\
\hline Reference & 2.44 & 0.93 & 0.00 & -0.13 & 0.04 & 0.78 & -0.75 & 3.30 \\
\hline No Taxes & 2.72 & 0.93 & 0.00 & 0.00 & 0.00 & 0.00 & 0.00 & 3.65 \\
\hline No Property Tax & 2.44 & 0.93 & 0.00 & -0.13 & 0.04 & 0.00 & -0.75 & 2.52 \\
\hline No Input Taxes & 2.27 & 0.93 & 0.00 & -0.15 & -0.03 & 0.73 & -0.75 & 3.00 \\
\hline No State Income Tax & 2.49 & 0.93 & 0.00 & -0.11 & 0.07 & 0.78 & -0.75 & 3.40 \\
\hline No Fed Tax/Credits & 2.84 & 0.93 & 0.00 & 0.00 & 0.13 & 0.78 & 0.00 & 4.68 \\
\hline Tax Life = Book & 2.91 & 0.93 & 0.00 & 0.12 & 0.09 & 0.78 & -0.75 & 4.08 \\
\hline No Tax Credits & 2.44 & 0.93 & 0.00 & 0.28 & 0.12 & 0.78 & 0.00 & 4.54 \\
\hline CWIP & 2.44 & 0.93 & 0.00 & -0.13 & 0.04 & 0.78 & -0.75 & 3.31 \\
\hline Flow-Thru Taxes & 2.91 & 0.93 & 0.00 & -0.18 & 0.04 & 0.78 & -0.75 & 3.73 \\
\hline No Fuel Adj. Clause & 2.44 & 0.93 & 0.00 & -0.13 & 0.04 & 0.78 & -0.75 & 3.30 \\
\hline
\end{tabular}


Table B.16

Levelized Cost Components ( $(\mathrm{k} / \mathrm{kWh})$,

Coal

\begin{tabular}{|c|c|c|c|c|c|c|c|c|}
\hline & Capital & O\&M Cost & Fuel Cost & Fed. Tax & State/Local & Prop. Tax & Tax Credit & Total Cost \\
\hline Reference & 1.97 & 1.15 & 1.74 & 0.32 & 0.23 & 0.49 & 0.00 & 5.90 \\
\hline No Taxes & 1.96 & 1.15 & 1.74 & 0.00 & 0.00 & 0.00 & 0.00 & 4.85 \\
\hline No Property Tax & 1.97 & 1.15 & 1.74 & 0.32 & 0.23 & 0.00 & 0.00 & 5.41 \\
\hline No Input Taxes & 1.84 & 1.15 & 1.74 & 0.30 & 0.05 & 0.46 & 0.00 & 5.54 \\
\hline No State Income Tax & 1.98 & 1.15 & 1.74 & 0.33 & 0.17 & 0.49 & 0.00 & 5.87 \\
\hline No Fed Tax/Credits & 2.08 & 1.15 & 1.74 & 0.00 & 0.22 & 0.49 & 0.00 & 5.68 \\
\hline Tax Life = Book & 2.08 & 1.15 & 1.74 & 0.38 & 0.24 & 0.49 & 0.00 & 6.08 \\
\hline No Tax Credits & 1.97 & 1.15 & 1.74 & 0.32 & 0.23 & 0.49 & 0.00 & 5.90 \\
\hline CWIP & 1.97 & 1.15 & 1.74 & 0.33 & 0.23 & 0.49 & 0.00 & 5.92 \\
\hline Flow-Thru Taxes & 2.10 & 1.15 & 1.74 & 0.34 & 0.23 & 0.49 & 0.00 & 6.05 \\
\hline No Fuel Adj. Clause & 1.97 & 1.15 & 1.74 & 0.32 & 0.23 & 0.49 & 0.00 & 5.90 \\
\hline
\end{tabular}


Table B.17

Levelized Cost Components ( $\mathrm{c} / \mathrm{kWh}$ ),

Combined Cycle

\begin{tabular}{|c|c|c|c|c|c|c|c|c|}
\hline$\cdot$ & Capital & O\&M Cost & Fuel Cost & Fed. Tax & State/Local & Prop. Tax & Tax Credit & Total Cost \\
\hline Reference & 1.59 & 0.50 & 3.06 & 0.25 & 0.24 & 0.42 & 0.00 & 6.06 \\
\hline No Taxes & 1.58 & 0.50 & 3.06 & 0.00 & 0.00 & 0.00 & 0.00 & 5.14 \\
\hline No Property Tax & 1.59 & 0.50 & 3.06 & 0.25 & 0.24 & 0.00 & 0.00 & 5.65 \\
\hline No Input Taxes & 1.48 & 0.50 & 3.06 & 0.24 & 0.04 & 0.39 & 0.00 & 5.72 \\
\hline No State Income Tax & 1.60 & 0.50 & 3.06 & 0.26 & 0.19 & 0.42 & 0.00 & 6.03 \\
\hline No Fed Tax/Credits & 1.68 & 0.50 & 3.06 & 0.00 & 0.23 & 0.42 & 0.00 & 5.89 \\
\hline Tax Life = Book & 1.68 & 0.50 & 3.06 & 0.30 & 0.25 & 0.42 & 0.00 & 6.21 \\
\hline No Tax Credits & 1.59 & 0.50 & 3.06 & 0.25 & 0.24 & 0.42 & 0.00 & 6.06 \\
\hline CWIP & 1.59 & 0.50 & 3.06 & 0.26 & 0.24 & 0.42 & 0.00 & 6.07 \\
\hline Flow-Thru Taxes & 1.69 & 0.50 & 3.06 & 0.27 & 0.24 & 0.42 & 0.00 & 6.19 \\
\hline No Fuel Adj. Clause & 1.59 & 0.50 & 3.06 & 0.25 & 0.24 & 0.42 & 0.00 & 6.06 \\
\hline
\end{tabular}


Table B.18

Levelized Cost Components ( $\$ / k W h)$,

Combustion Turbine

\begin{tabular}{|c|c|c|c|c|c|c|c|c|}
\hline & Capital & O\&M Cost & Fuel Cost & Fed. Tax & State/Local & Prop. Tax & Tax Credit & Total Cost \\
\hline Reference & 2.56 & 0.52 & 4.63 & 0.36 & 0.33 & 0.73 & 0.00 & 9.13 \\
\hline ito Taxes & 2.62 & 0.52 & 4.63 & 0.00 & 0.00 & 0.00 & 0.00 & 7.77 \\
\hline No Property Tax & 2.56 & 0.52 & 4.63 & 0.36 & 0.33 & 0.00 & 0.00 & 8.40 \\
\hline No Input Taxes & 2.39 & 0.52 & 4.63 & 0.34 & 0.06 & 0.68 & 0.00 & 8.61 \\
\hline No State Income Tax & 2.59 & 0.52 & 4.63 & 0.37 & 0.27 & 0.73 & 0.00 & 9.10 \\
\hline No Fed Tax/Credits & 2.77 & 0.52 & 4.63 & 0.00 & 0.33 & 0.73 & 0.00 & 8.97 \\
\hline Tax Life = Book & 2.81 & 0.52 & 4.63 & 0.49 & 0.36 & 0.73 & 0.00 & 9.53 \\
\hline No Tax Credits & 2.56 & 0.52 & 4.63 & 0.36 & 0.33 & 0.73 & 0.00 & 9.13 \\
\hline CWIP & 2.56 & 0.52 & 4.63 & 0.36 & 0.33 & 0.73 & 0.00 & 9.13 \\
\hline Flow-Thru Taxes & 2.81 & 0.52 & 4.63 & 0.33 & 0.33 & 0.73 & 0.00 & 9.34 \\
\hline No Fuel Adj. Clause & 2.56 & 0.52 & 4.62 & 0.36 & 0.33 & 0.73 & 0.00 & 9.12 \\
\hline
\end{tabular}


Table B.19

Levelized Cost Components ( $\$ / k W h)$,

Nuclear

\begin{tabular}{|c|c|c|c|c|c|c|c|c|}
\hline & Capital & O\&M Cost & Fuel Cost & Fed. Tax & State/Local & Prop. Tax & Tax Credit & Total Cost \\
\hline Reference & 1.89 & 2.38 & 0.46 & 0.30 & 0.25 & 0.47 & 0.00 & 5.75 \\
\hline No Taxes & 1.94 & 2.38 & 0.46 & 0.00 & 0.00 & 0.00 & 0.00 & 4.78 \\
\hline No Property Tax & 1.89 & 2.38 & 0.46 & 0.30 & 0.25 & 0.00 & 0.00 & 5.28 \\
\hline No Input Taxes & 1.76 & 2.38 & 0.46 & 0.28 & 0.05 & 0.44 & 0.00 & 5.37 \\
\hline No State Income Tax & 1.91 & 2.38 & 0.46 & 0.31 & 0.20 & 0.47 & 0.00 & 5.73 \\
\hline No Fed Tax/Credits & 2.05 & 2.38 & 0.46 & 0.00 & 0.25 & 0.47 & 0.00 & 5.60 \\
\hline Tax Life = Book & 2.05 & 2.38 & 0.46 & 0.39 & 0.27 & 0.47 & 0.00 & 6.01 \\
\hline No Tax Credits & 1.89 & 2.38 & 0.46 & 0.30 & 0.25 & 0.47 & 0.00 & 5.75 \\
\hline CWIP & 1.89 & 2.38 & 0.46 & 0.31 & 0.26 & 0.47 & 0.00 & 5.77 \\
\hline Flow-Thru Taxes & 2.08 & 2.38 & 0.46 & 0.27 & 0.25 & 0.47 & 0.00 & 5.90 \\
\hline No Fuel Adj. Clause & 1.89 & 2.38 & 0.46 & 0.30 & 0.25 & 0.47 & 0.00 & 5.75 \\
\hline
\end{tabular}


APPENDIX C: RELATIVE BARRIERS AND INCENTIVES

C-1 
Table C.1

Comparison of Tax Effects on Renewables to Conventionals,

Investor-Owned Utilities

(Difference in Levelized Cost Ratio from Average Conventional Cost Ratio)

\begin{tabular}{|c|c|c|c|c|c|c|c|}
\hline Generating Type & $\begin{array}{c}\text { Effect of } \\
\text { Including } \\
\text { All Taxes } \\
\text { and Credits }\end{array}$ & $\begin{array}{c}\text { Effect of } \\
\text { Including } \\
\text { Property Taxes }\end{array}$ & $\begin{array}{l}\text { Effect of } \\
\text { Including } \\
\text { Input Taxes }\end{array}$ & $\begin{array}{c}\text { Effect of } \\
\text { Including } \\
\text { State } \\
\text { Income Taxes }\end{array}$ & $\begin{array}{l}\text { Effect of } \\
\text { Including } \\
\text { Federal Taxes } \\
\text { and Credits }\end{array}$ & $\begin{array}{c}\text { Effect of } \\
\text { Accelerated } \\
\text { Depreciation }\end{array}$ & $\begin{array}{l}\text { Effect of Fed } \\
\text { Tax Credits }\end{array}$ \\
\hline Average Conventional & 1.194 & 1.085 & 1.064 & 1.005 & 1.028 & 0.965 & 1.000 \\
\hline \multicolumn{8}{|c|}{ Renewable - Avg. Conventional } \\
\hline Biomass-Plantation & -0.220 & 0.000 & 0.010 & -0.011 & -0.174 & 0.007 & -0.170 \\
\hline Biomass-Waste & -0.005 & -0.006 & -0.002 & 0.001 & 0.004 & 0.009 & 0.000 \\
\hline Geothermal & -0.030 & 0.029 & 0.008 & -0.008 & -0.050 & -0.064 & 0.000 \\
\hline Hydro & 0.207 & 0.155 & 0.007 & 0.002 & 0.009 & -0.070 & 0.000 \\
\hline Solar-Photovoltaic & 0.074 & 0.188 & 0.007 & -0.014 & -0.080 & -0.153 & 0.000 \\
\hline Solar-Thermal & 0.046 & 0.146 & 0.007 & -0.013 & -0.074 & -0.133 & 0.000 \\
\hline Wind & -0.288 & 0.224 & 0.036 & -0.034 & -0.322 & -0.155 & -0.272 \\
\hline
\end{tabular}

Source: Tables 5.1, 5.3

Positive values indicate greater barrier (or less incentive) to Renewables than to Conventionals. Negative values indicate greater incentive (or less barrier) to Renewables than to Conventionals. 
Table C.2

Comparison of Ratemaking Effects on Renewables to Conventionals, Investor-Owned Utilities

(Difference in Levelized Cost Ratio from Average Conventional Cost Ratio)

\begin{tabular}{llll}
\hline Generating Type & $\begin{array}{c}\text { Effect of Not } \\
\text { Including CWIP } \\
\text { in Rate Base }\end{array}$ & $\begin{array}{c}\text { Effect of } \\
\text { Normalizing } \\
\text { Taxes in Rate Base }\end{array}$ & $\begin{array}{c}\text { Effect of Automatic } \\
\text { Fudjustments }\end{array}$ \\
\hline Average Conventional & 1.000 & 0.990 & 1.001 \\
Renewable-Avg. Conventional & & & \\
Biomass-Plantation & -0.001 & -0.012 & -0.001 \\
Biomass-Waste & -0.001 & -0.011 & -0.001 \\
Geothermal & -0.001 & -0.047 & -0.001 \\
Hydro & -0.004 & -0.090 & -0.001 \\
Solar-Photovoltaic & 0.000 & -0.102 & -0.001 \\
Solar-Thermal & 0.000 & -0.089 & -0.001 \\
Wind & -0.001 & -0.104 & -0.001 \\
\hline
\end{tabular}

\section{Source: Table 5.2}

Positive values indicate greater barrier (or less incentive) to Renewables than to Conventionals. Negative values indicate greater incentive (or less barrier) to Renewables than to Conventionals. 
Table C. 3

Comparison of Tax Effects on Renewables to Conventionals, Nonutility Generators

(Difference in IRR Ratio from Average Conventional IRR Ratio)

\begin{tabular}{|c|c|c|c|c|c|c|}
\hline Generating Type & $\begin{array}{l}\text { Effect of } \\
\text { Including } \\
\text { All Taxes } \\
\text { and Credits }\end{array}$ & $\begin{array}{c}\text { Effect of } \\
\text { Including } \\
\text { Property Taxes }\end{array}$ & $\begin{array}{c}\text { Effect of } \\
\text { Includling } \\
\text { Input Taxes }\end{array}$ & $\begin{array}{l}\text { Effect of Includ- } \\
\text { ing State } \\
\text { Income Taxes }\end{array}$ & $\begin{array}{c}\text { Effect of } \\
\text { Including } \\
\text { Federal Taxes } \\
\text { and Credits }\end{array}$ & $\begin{array}{c}\text { Effect of } \\
\text { Including } \\
\text { Alternative } \\
\text { Minimum Tax }\end{array}$ \\
\hline Average Conventional & 0.607 & 0.815 & 0.851 & 0.991 & 0.937 & 0.957 \\
\hline \multicolumn{7}{|c|}{ Renewable - Avg. Conventional } \\
\hline Biomass-Plantation & 0.921 & -0.006 & -0.022 & 0.060 & 4.619 & -0.272 \\
\hline Biomass-Waste & 0.103 & 0.009 & 0.008 & 0.017 & 0.125 & -0.183 \\
\hline Geothermal & 0.218 & -0.001 & 0.020 & 0.027 & 0.354 & -0.210 \\
\hline Hydro & 0.102 & 0.010 & 0.080 & 0.007 & 0.053 & -0.049 \\
\hline Solar-Photovoltaic & 0.291 & -0.030 & 0.072 & 0.033 & 0.445 & -0.248 \\
\hline Solar-Thermal & 0.280 & -0.029 & 0.063 & 0.033 & 0.441 & -0.246 \\
\hline Wind & 0.740 & -0.065 & 0.030 & 0.064 & 2.644 & -0.312 \\
\hline
\end{tabular}

Source: Table 6.1

Positive values indicate greater incentive (or less barrier) to Renewables than to Conventionals. Negative values indicate greater barrier (or less incentive) to Renewables than to Conventionals. 
Table C.4

Comparison of Tax Effects on Renewables :o Conventionals,

Nonutility Generators

(Difference in Change in IRR from Change in IRR for Avg. Conventionals)

\begin{tabular}{|c|c|c|c|c|c|c|}
\hline Generating Type & $\begin{array}{l}\text { Effect of } \\
\text { Including } \\
\text { All Taxes } \\
\text { and Credits }\end{array}$ & $\begin{array}{c}\text { Effect of } \\
\text { Including } \\
\text { Property Taxes }\end{array}$ & $\begin{array}{l}\text { Effect of } \\
\text { Includling } \\
\text { Input Taxes }\end{array}$ & $\begin{array}{l}\text { Effect of Includ- } \\
\text { ing State } \\
\text { Income Taxes }\end{array}$ & $\begin{array}{l}\text { Effect of } \\
\text { Including } \\
\text { Federal Taxes } \\
\text { and Credits }\end{array}$ & $\begin{array}{c}\text { Effect of } \\
\text { Including } \\
\text { Alternative } \\
\text { Minimum Tax }\end{array}$ \\
\hline Average Conventional & $-4.24 \%$ & $-1.47 \%$ & $-1.13 \%$ & $-0.06 \%$ & $-0.44 \%$ & $-0.28 \%$ \\
\hline \multicolumn{7}{|c|}{ Renewable - Avg. Conventional } \\
\hline Biomass-Plantation & $6.98 \%$ & $-0.40 \%$ & $-0.50 \%$ & $0.44 \%$ & $6.94 \%$ & $-2.22 \%$ \\
\hline Biomass-Waste & $1.26 \%$ & $-0.08 \%$ & $-0.07 \%$ & $0.12 \%$ & $0.86 \%$ & $-1.37 \%$ \\
\hline Geothermal & $2.69 \%$ & $-0.20 \%$ & $0.05 \%$ & $0.18 \%$ & $2.08 \%$ & $-1.57 \%$ \\
\hline Hydro & $1.73 \%$ & $0.18 \%$ & $0.68 \%$ & $0.05 \%$ & $0.37 \%$ & $-0.29 \%$ \\
\hline Solar-Photovoltaic & $3.41 \%$ & $-0.53 \%$ & $0.52 \%$ & $0.23 \%$ & $2.47 \%$ & $-1.86 \%$ \\
\hline Solar-Thermal & $3.30 \%$ & $-0.53 \%$ & $0.44 \%$ & $0.23 \%$ & $2.46 \%$ & $-1.85 \%$ \\
\hline Wind & $5.91 \%$ & $-0.69 \%$ & $0.25 \%$ & $0.40 \%$ & $5.12 \%$ & $-2.03 \%$ \\
\hline
\end{tabular}

Source: Table 6.1

Positive values indicate greater incentive (or less barrier) to Renewables than to Conventionals. Negative values indicate greater barrier (or less incentive) to Renewables than to Conventionals. 


\section{INTERNAL DISTRIBUTION}

1-25. T.D. Anderson

26. F.P. Baxter

27. V. Baxter

28. R.B. Braid

29. M. Brown

30. S.A. Carnes

31. J. Christian

32. R.C. Devault

33. A.E. Ekkebus

34. P.D. Fairchild

35. D.L. Feldman

36. P.S. Gillis

37. D.L. Greene

38. J.L. Hardee

338. L.J. Hill

339. E.L. Hillsman

340 P.J. Hughes

341. J.E. Johnson

342. D.W. Jones

343. S.V. Kaye

344. C.R. Kerley

345. J.O. Kolb

346 M.A. Kuliasha
345. R. Lee

346. P.N. Leiby

347. L.N. McCold

348. V.C. Mei

349. W.R. Nelson

350. R.D. Perlack

351. S. Rayner

352. D.E. Reichle

353. J.R. Sand

354. J. Sheffield

355. R.B. Shelton

356. D.P. Vogt

357. D.A. Waters

358. D.L. White

359. David Baumgardner

360. T.J. Wilbanks

361. B.Y. Wilkes

362. ORNL Patent Office

363. Central Research Library

364. Document Reference Section

367. Laboratory Records

368. Laboratory Records - RC

\section{EXTERNAL DISTRIBUTION}

369. J.G. Asbury, Argonne National Laboratory, 9700 South Cass Avenue, Argonne, IL 60439

370. Computer Science Department, University of Pittsburgh, 206 Mineral Industries Building, Pittsburgh, PA 15260

371. M.A. Chartock, University of California, Lawrence Berkeley Laboratory, One Cyclotron Road, Berkeley, CA 94720

372. Vice President, End Use, Research and Development, Gas Research Institute, 8600 W. Bryn Mawr Avenue, Chicago, IL 60631

373. Vice President, Environmental Sciences and Director, Washington Operations, Midwest Research Institute, 5109 Leesburg Pike, Suite 414, Falls Church, VA 22041

374. C. Keyes, University of California, Lawrence Livermore National Laboratory, P.O. Box 808, Livermore, CA 94550

375. R.C. Liikala, Pacific Northwest Laboratory, Battelle Blvd., P.O. Box 999, Richland, WA 99352 
376. R. Morales, University of California, Los Alamos National Laboratory, P.O. Box 166., Los Alamos, NM 87545

377. M. Sakitt, Brookhaven National Laboratory, Upton, NY 11973

378. G. Yonas, Sandia National Laboratory, P.O. Box 5800, Albuquerque, NM 87185

379. Office of Assistant Manager for Energy Research and Development, DOE-ORO, P.O. Box 2001, Oak Ridge, TN 38831-8600

380. OSTI, U.S. Department of Energy, P.O. Box 62, Oak Ridge, TN 37831

\section{ENERGY DIVISION ADVISORY COMMITTEE}

381. Dr. Douglas R. Bohi, Director, Energy and Natural Resources Division, Resources for the Future, 1616 P Street, N.W., Washington, DC 20036

382. Dr. Thomas E. Drabek, Professor, Department of Sociology, University of Denver, Denver, Colorado 80208-0209

383. Mr. Calvin D. MacCracken, President, Calmac Manufacturing Corporation, 101 West Sheffield Avenue, P.O. Box 710, Englewood, NJ 07631

384. Ms. Jacqueline B. Shrago, Director, Office of Technology Transfer, 405 Kirkland Hall, Vanderbilt University, Nashville, TN 37240

385. Mr. George F. Sowers, P.E., Senior Vice President, Law companies Group, Inc. 114 Townpark Drive, Suite 250, Kennesaw, GA 30144-5599

386. Dr. C. Michael Walton, Paul D. and Betty Robertson Meek Centennial, Professor and Chairman, Department of Civil Engineering, College of Engineering, The University of Texas at Austin, Cockrell Hall, Suite 4.2, Austin, Texas 78712 

,
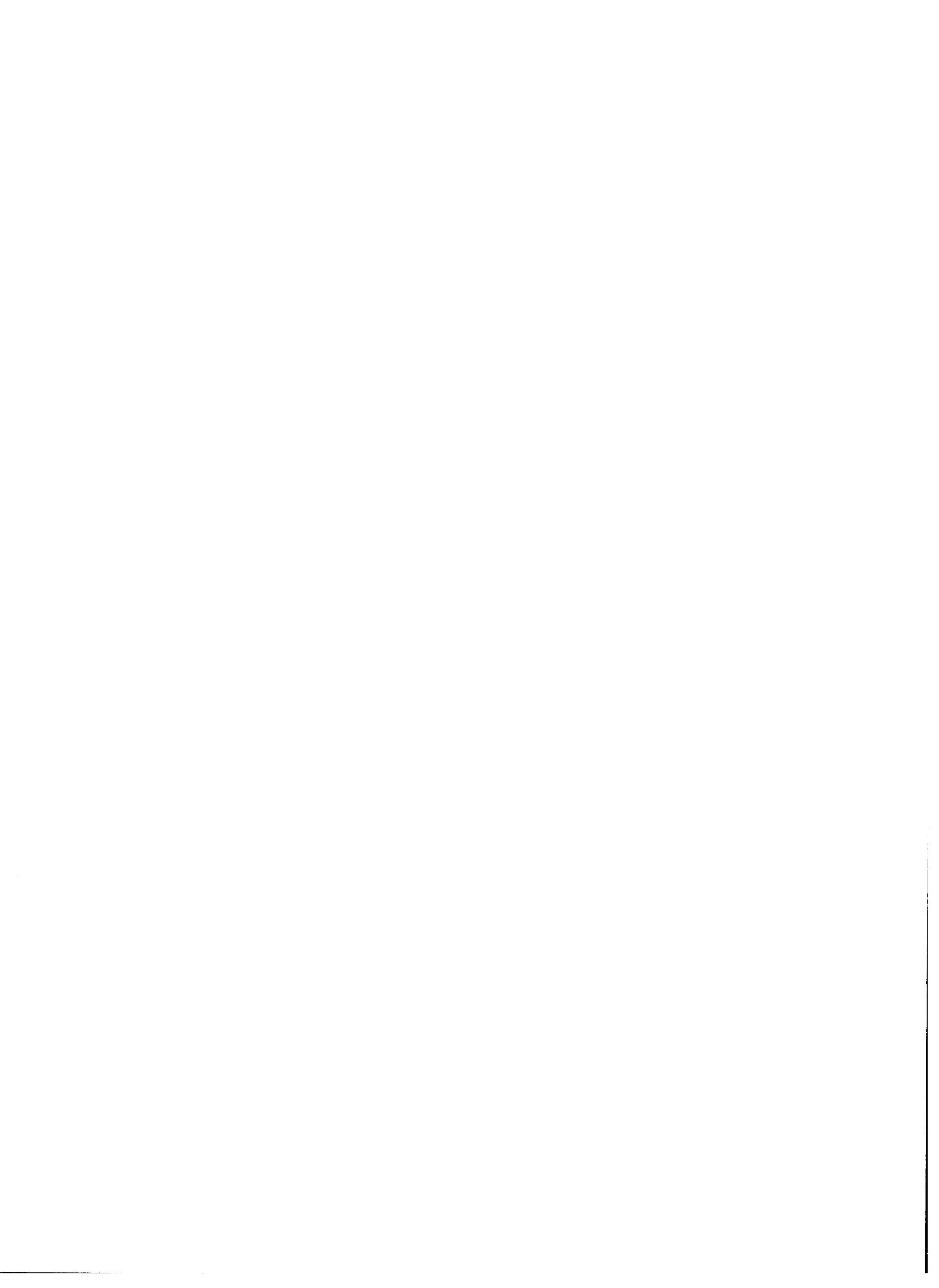

$-$ 